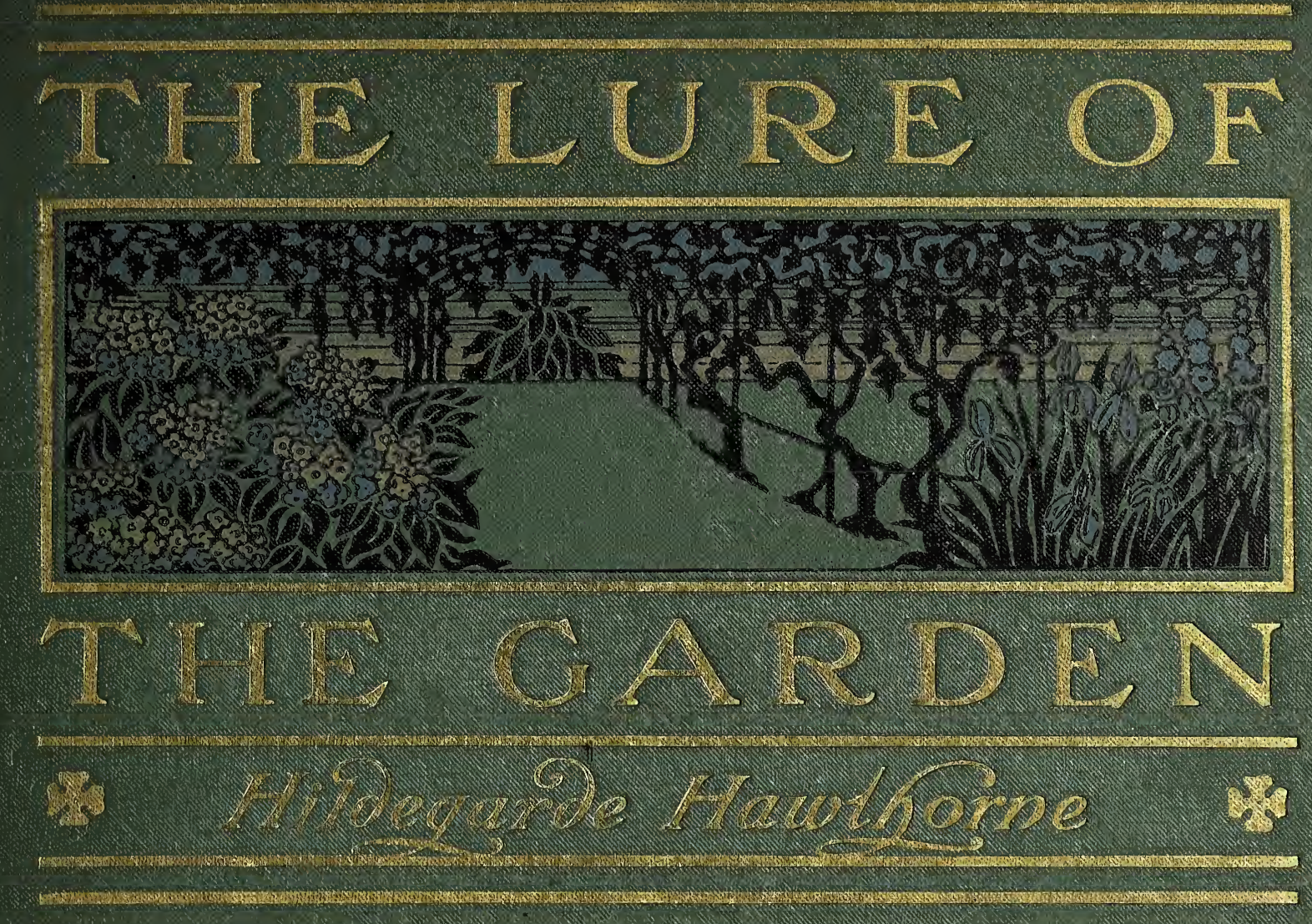




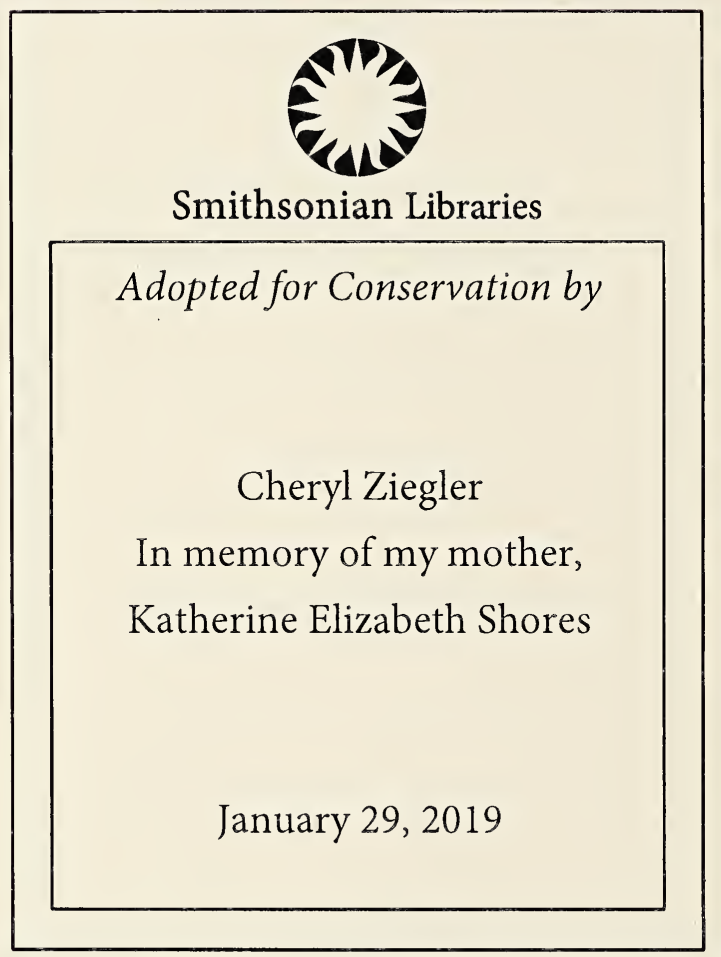





$$
\frac{d}{b e d} \text { nit }
$$


THE LURE

OF THE GARDEN 




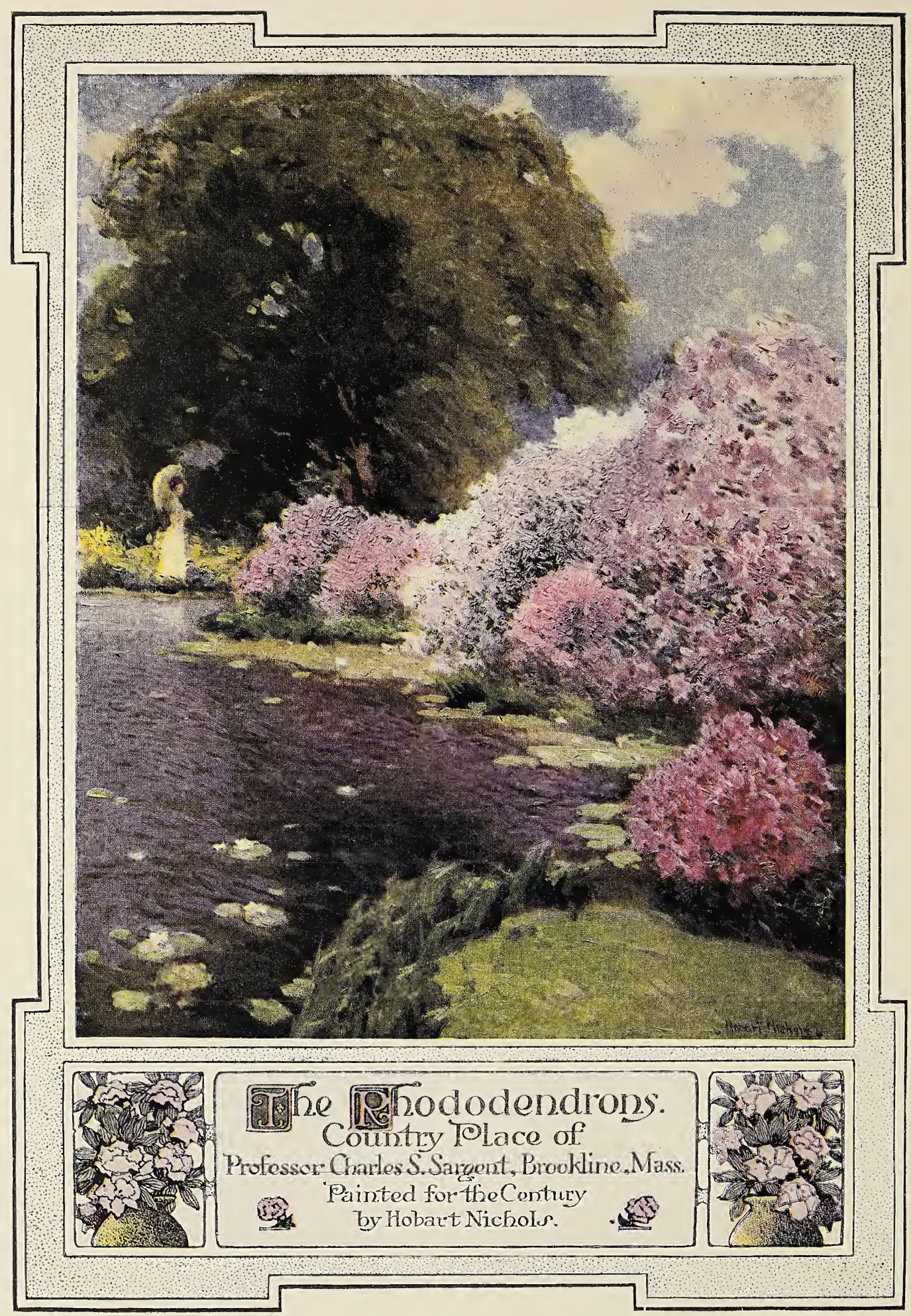




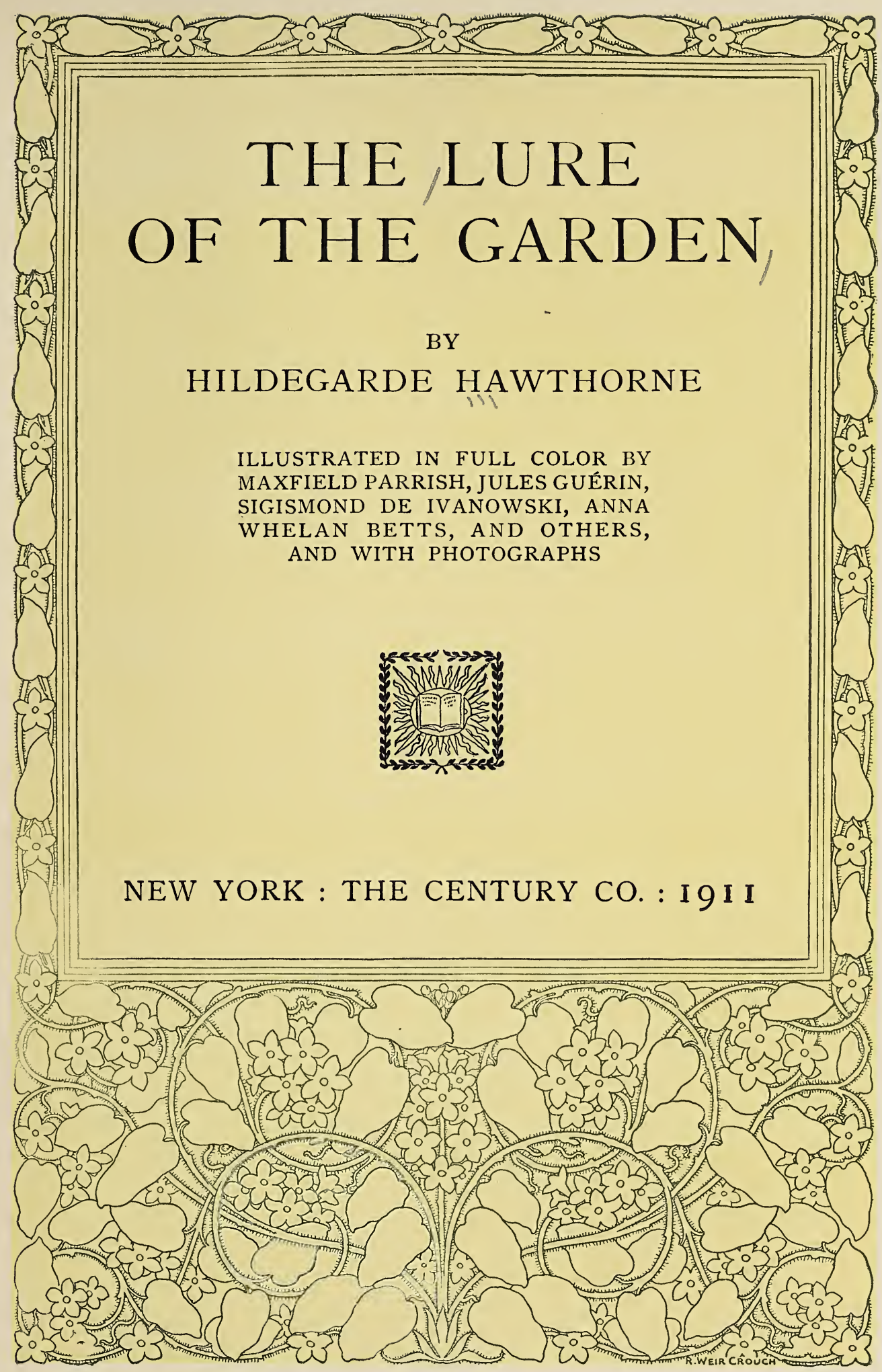


Copyright, I9I I, by

The Century Co.

Published, October, IQII 
TO

MY MOTHER

WHO LOVES ALL GREEN GROWTH, AND HAS PLANTED MANY A GARDEN I INSCRIBE THIS BOOK OF MINE 



\section{CONTENTS}

INTRODUCTION

PAGK

I

OUR GRANDMOTHER'S GARDENS . . • • • . 2 I

II

WASHINGTON'S GARDEN . . . . . . . . . . . 45

III

CHILDHOOD IN THE GARDEN . . . . . . 63

IV

THE SOCIAL SIDE OF GARDENS . . . . . . 85

$\mathrm{V}$

GARDENS AND GOSSIPS .. . . . . . . . IO7

VI

GARDENS OF SOME WELL-KNOWN PEOPLE . . . I25

VII

SOME GARDEN VICES . . . . . . . . . I45

vii 


\section{CONTENTS}

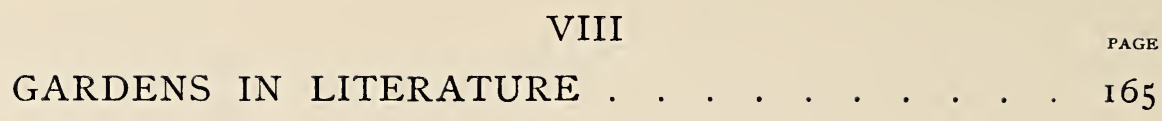

GARDEN GATES . . . . . . . . . . . . . . . IXI

$\mathrm{X}$

GARDENS PUBLIC AND BOTANICAL . . . . . 2 II

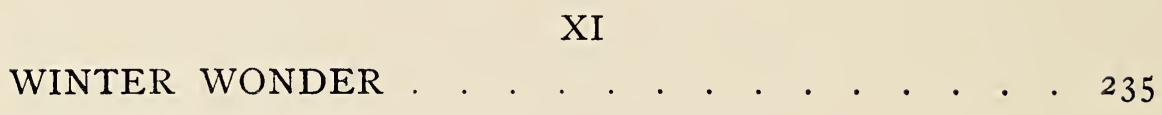

XII

POSSIBILITIES OF THE FUTURE $\quad$. . . . . 247 


\section{LIST OF ILLUSTRATIONS}

"Rhododendrons from the Himalayas" Frontispiece

Wistaria on an Old Colonial House . . . . . . . . . . 4

The Entrance to an Italian Garden . . . . . . . . . . 9

Foxglove and Roses and Canterbury-Bells . . . . . . . 14

"Along the Paths Walked the Great-Grandmother" . . . . 20

Climbing-Roses Over a Porch . . . . . . . . . . 25

Square Terraces Step Downward from the House . . . . . 29

"Herself as Lovely as Any Flower that Grew" . . . . . . 33

A Charleston Garden . . . . . . . . . . . . 38

Nelly Custis in the Mount Vernon Garden . . . . . . . 44

The Old Watchman on His Rounds Again . . . . . . 49

The Long, Straight Rows of Flowers . . . . . . . . 53

“How Well a Child Becomes the Garden” . . . . . . . 62

A Pathway Bordered with Box . . . . . . . . . . 66

A Garden Wall . . . . . . . . . . . . . 70

"Let Them Live Close to Its Flowers" . . . . . . . 73

A Place to Dream and Linger in . . . . . . . . . 77

"Before the Time of Formal Gardens" . . . . . . . . 84

A Visit on the Lawn in the Olden Time . . . . . . . . 94

Through Green Arbors . . . . . . . . . . . . . 99

"Gossip is Not Necessarily Unkind" . . . . . . . . . 106

A Garden Path . . . . . . . . . . . . . . . II4 


\section{LIST OF ILLUSTRATIONS}

The Path by the Long Pond . . . . . . . . . . II 7

Vistas of White and Green . . . . . . . . . . . . I 24

Where House and Garden Meet . . . . . . . . . I27

Entrance to a Cornish Garden . . . . . . . . . . I 32

The Poplars at Augustus Saint-Gaudens's House, Cornish . . I37

"The Mildest and Best-Behaved of Gardens" . . . . . . I44

A Pergola . . . . . . . . . . . . . . . . . . I47

Grass-Bordered Beds . . . . . . . . . . . . . $\mathrm{I}_{52}$

A July Evening . . . . . . . . . . . . . . I 56

"Within High Walls and Jealous Hedges" . . . . . . . I64

Terraces and Pools in a Persian Garden . . . . . . . . 167

At the End of the Terrace-Walk . . . . . . . . I72

A Place of Continual Enjoyment . . . . . . . . . . I77

“The Golden Dream Beyond” . . . . . . . . . . I83

"A Hint to the Imagination of Each Passer-by" . . . . . I90

Entrance to a Garden Through an Avenue of Pines . . . . 194

Cloisters, Many-Arched . . . . . . . . . . . 203

"In the Garden a Breathing Fragrance" . . . . . . . . 210

Pools and Silences . . . . . . . . . . . . . . 2 I 3

Where the Shrubbery Reaches High . . . . . . . 220

The Enchantment of Green . . . . . . . . . . 225

A Winter Bouquet . . . . . . . . . . . . 234

"For a Garden in Winter is a Lovely Thing- - " . . . . . 239

“This Delicious Solitude” . . . . . . . . . . . 246

Lotus and Water-Lilies in a Japanese Garden . . . . . 252

Pool and Pergola . . . . . . . . . . . . . 255 


\section{THE LURE OF THE}

GARDEN 


\title{
GARDEN SONG
}

\author{
BY AUSTIN DOBSON
}

Here in this sequestered close Bloom the hyacinth and rose, Here beside the modest stock Flaunts the flaring hollyhock; Here, without a pang, one sees Ranks, conditions and degrees.

All the seasons run their race In this quiet resting-place;

Peach and apricot and fig Here will ripen and grow big; Here is store and overplus,More had not Alcinous.

Here, in alleys cool and green, Far ahead the thrush is seen; Here along the southern wall Keeps the bee his festival; All is quiet else - afar Sounds of toil and turmoil are.

Here be shadows large and long; Here be spaces meet for song; Grant, $\mathrm{O}$ garden-god, that $\mathrm{I}$, Now that none profane is nigh,Now that mood and moment please,Find the fair Pierides. 


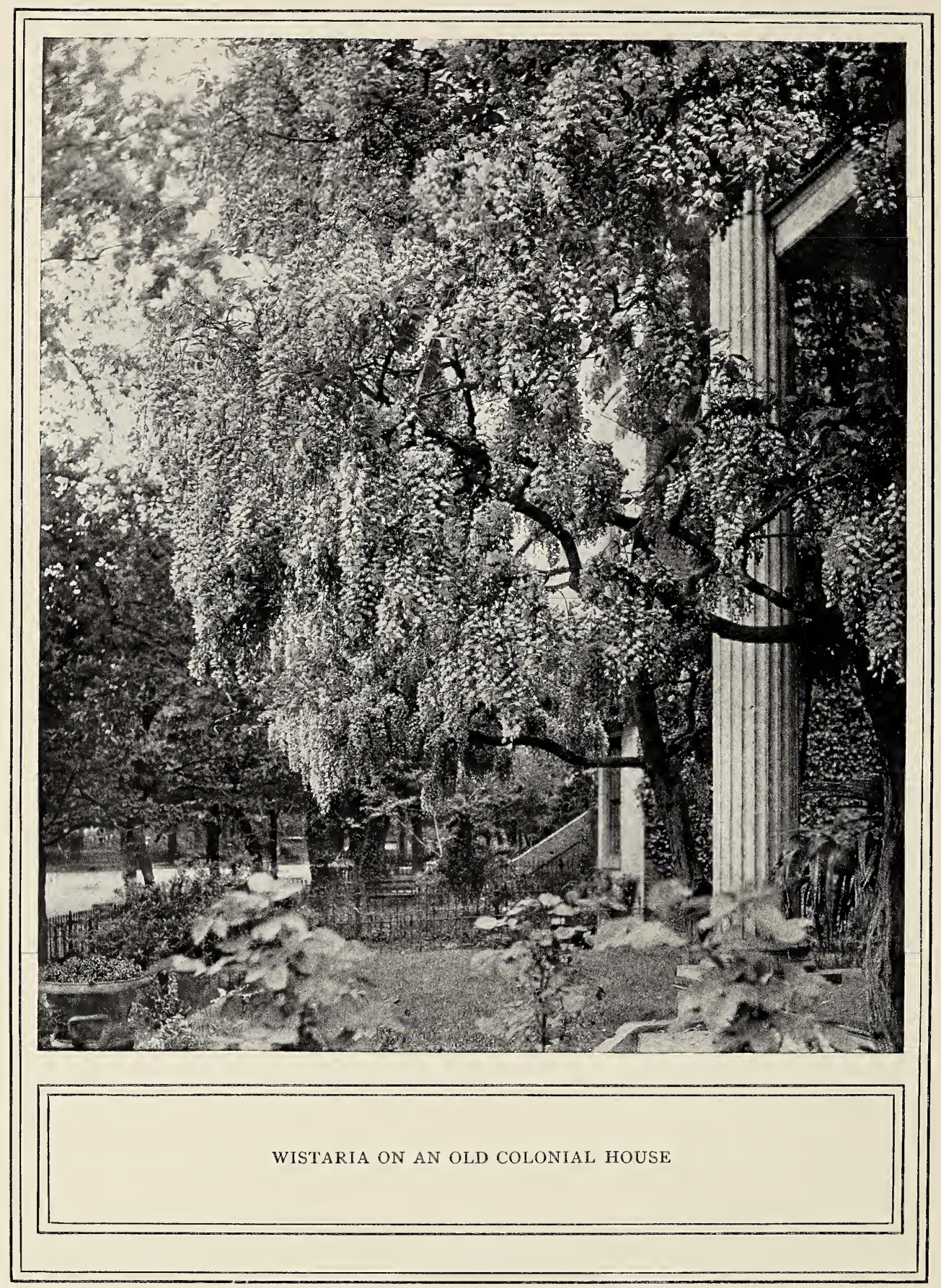




\section{THE LURE OF THE GARDEN}

\section{INTRODUCTION}

$\mathbf{I}$

$\mathrm{N}$ spite of its material of green leaf and fragrant flower, a garden is the work of man. It requires and yields a return that is peculiarly mingled of nature and art, bestowing upon any who enter its exquisite precincts something of the sanity, wholesomeness, and simplicity of the world of out-of-doors, together with the better portion of the grace, interest, and social charm of the world within the house. Its fountains murmur a lilt not too distant from the laughter or the tears of those who carved the stone basins into which the water drips. In bower and green way a comprehending solitude lies waiting for whoever comes to seek its quiet pleasures, and there is hardly a mood known to man for which the garden has neither solace nor inspiration. While any gathering of friends or 


\section{THE LURE OF THE GARDEN}

comrades becomes more intimate there, where even the shyest takes heart of grace, where the most self-conscious forgets to pose, where words come readily to the silent, and where silence is never irksome.

The garden, in fact, provides the most perfect of social backgrounds, possessing all the advantages and none of the drawbacks of its parents, the wilderness and the palace, those two extremes between which man moves, one the expression of all that lies beyond his control, the other the result of everything he has learned to force into his service.

There are few who do not feel at home in a garden. The roughest or most cultured, the simplest or the world-weary, the child, the woman of fashion, the energetic or the lazy, the materialist on his clod of earth, and the poet in his rainbow maze - all of us, saint and sinner, sad or gay, enter a garden as though it were our own, unoppressed by its most princely magnificence, touched and attracted by its simplest form.

The lure of the garden! It has drawn us from the beginning of history, and draws us now. Persian potentates and Egyptian queens in the days before Moses, delighted to live in one; and in the scurry of modern existence English M.P.'s and commuters' wives escape from the cares of state and the terrors of housekeeping to plunge into the mysteries of planting and pruning, renewing their strength like Antæus at every touch of mother earth. As for that special and curious order 


\section{INTRODUCTION}

of humanity, lovers, "Come into the garden," has been a universal cry with them, until lovers without gardens or gardens without lovers are equally unimaginable; possibly each exists, but it must be in a halt, amorphous fashion, pitiful to contemplate and tragic to endure.

Stories of gardens have come to us from the remotest times. The story of Eden is co-eval with the story of man himself, and many magic gardens have sent their spellbound legends down through the ages. The golden-appled gardens of Hesperides, the dim Elysian Fields where Orpheus sought his Euridice, Arabian places where strange fruit hangs on mysterious branches, with many another of fairy lore or folk tale. For it has always been the way of man to create in the region of the imagination a more perfect example of the earth-made, tangible thing he has been able to produce in the world of matter. Let him but love anything sufficiently and instantly he translates it to fairy-land, where it acquires an immortal loveliness, a consummate perfection beyond the reach of his earthly powers. Since gardens and mankind have always thus belonged together, it is no more than natural to suppose that they will continue in delicious proximity as long as eternity itself. And it is the sincere conviction of most that not only mansions, but gardens, are prepared for them in their future existence.

Like many good things, gardens improve with age. 


\section{THE LURE OF THE GARDEN}

Here in America there are necessarily none that are really old. For the red man was in no other way so truly a savage as in the fact that he knew nothing of gardens. Nevertheless, there are a few in the Old Dominion and in New England that date back almost as far as the white occupation, and which breathe the gracious perfume of a vanished day. In the generous climate of California, moreover, nature brings flower and vine and tree to so quick and vigorous a growth, and mellows the sun-kissed walls so soon after they are built, that the passage of time is scarcely needed to give these southern places all the beauty of longlapsed years.

Italy and England may well dispute the palm for supreme loveliness in gardens. The warm ardor of the former, the adoration of her people for art, form, color, for keeping outdoors and living among flowers, has evolved one beautiful expression of this art, as the moist fertility of England, the country life there, and the long tenure of the estates, with a distinct passion for growing things, has brought about its own consummation of perfection:

In the wonderful days of the Italian Renaissance, women took a keen joy in building and planting gardens that have survived to this day, and are among the most exquisite on earth. Much of the medieval life was passed in them. Here duchesses and princesses held court under the ilex and the rose; here the 


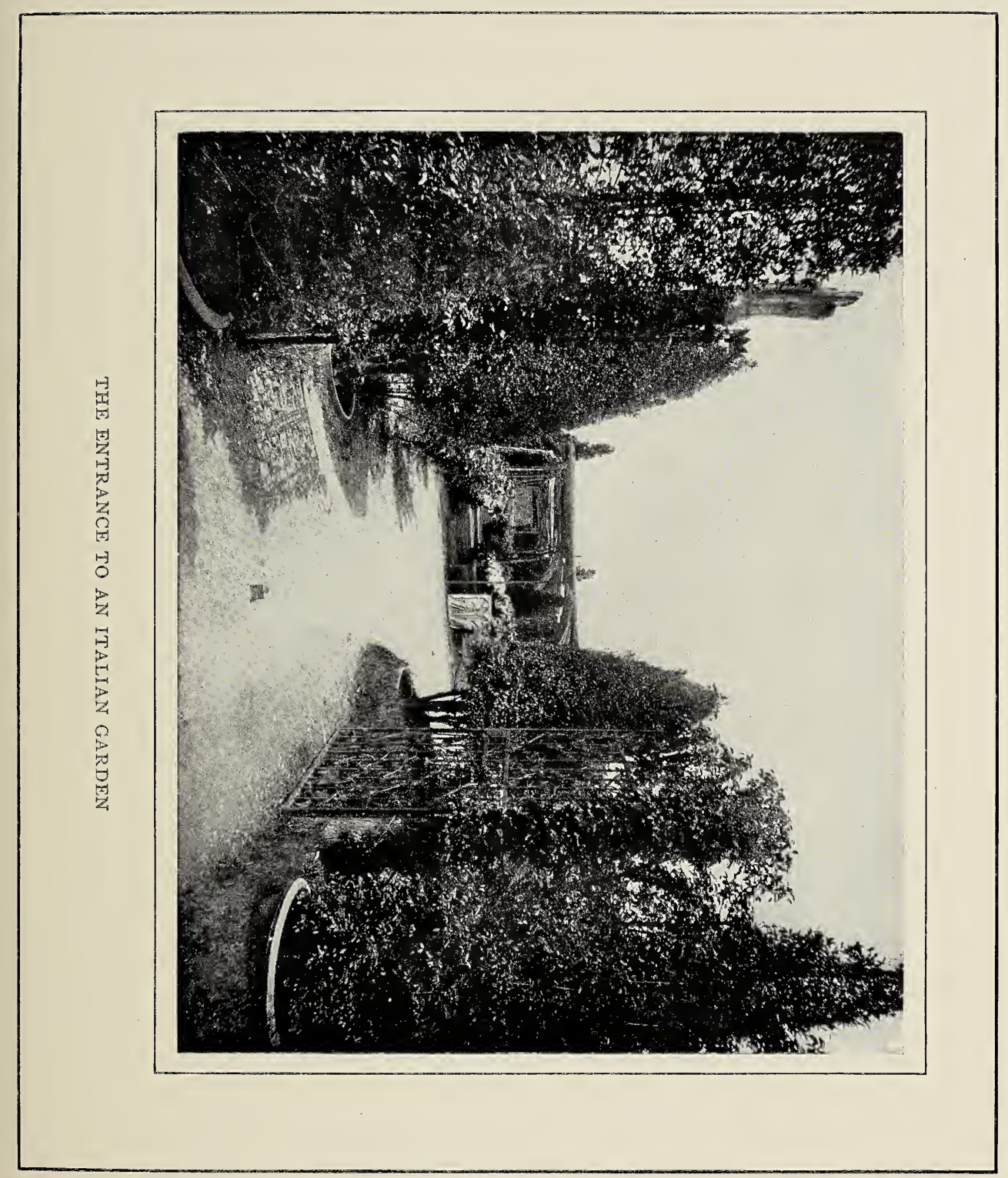





\section{INTRODUCTION}

gay, the noble, and the witty discussed or read the last poem, acted quaint masques, or sang to lute or viol passionate canzone destined for immortality. Beyond the marble balustrades flashed the bright sea or dreamed the purple mountains, and up and down the steps and past the fountains and the statues half hidden in green shade swept lords and ladies not less brilliant in color than the most splendid of the flowers about them.

It was in a garden outside the walls of Florence that the Boccaccio novelli were related day by day. No room, howsoever sumptuous, could be conceived of as holding that bright assemblage, could have set free the wit and romance of the story-tellers, as did the shady slopes and statue-haunted precincts of the great garden where they met. In the town were plague, horror, hateful death. In the garden a breathing fragrance, sweet health, and even merry hearts, or at least careless ones.

As for England, it is difficult to imagine her without terraced gardens where the grass is thicker than moss and greener than anywhere else on earth, where the great trees have flung their deep shadows in a mighty circle these many centuries, and where even in winter a pale rose will still find courage to bloom. Great gardens she has whose very names are history, and where the landscape artist has reached his apogee. And small gardens hushed within high walls, where the wall-flowers spill their musky odor and standard 


\section{THE LURE OF THE GARDEN}

roses step primly beside the path, and where the nightingale keeps the long June nights awake.

Here half the social life of England is passed. The small householder gives his garden quite as much care and thought as he does his house. He improves upon what his father has done, projects new plans and cherishes the old ones. At five o'clock he welcomes his friends there. And tea in an English garden is England at her best and most intimate. An English house seems forever leading you to its lawns and flower beds. The windows open on the green spaces or floweredged walks, its whole being turns to it, as it were. Here the nurse-maid sits of mornings at her sewing while the children dig in their own beds, or question the despotic old gardener, whose rules they must implicitly obey; while the afternoon brings the master from his work in the city for an hour or two's refreshment before dinner, and the evening sees the family and their guests, with a rug beneath them to guard against the ever-present dampness, taking their coffee and cigarettes on the lawn, while they listen to the nightingales. Here it is that the life of the home centers, finding among the flowers its greatest charm and freedom, yielding to casual caller or cherished guest its most delightful hospitality.

The following book is pledged to convey to its readers something of this social side of gardens old and new. Following no strict rule or formal plan, but 


$$
\text { , }
$$




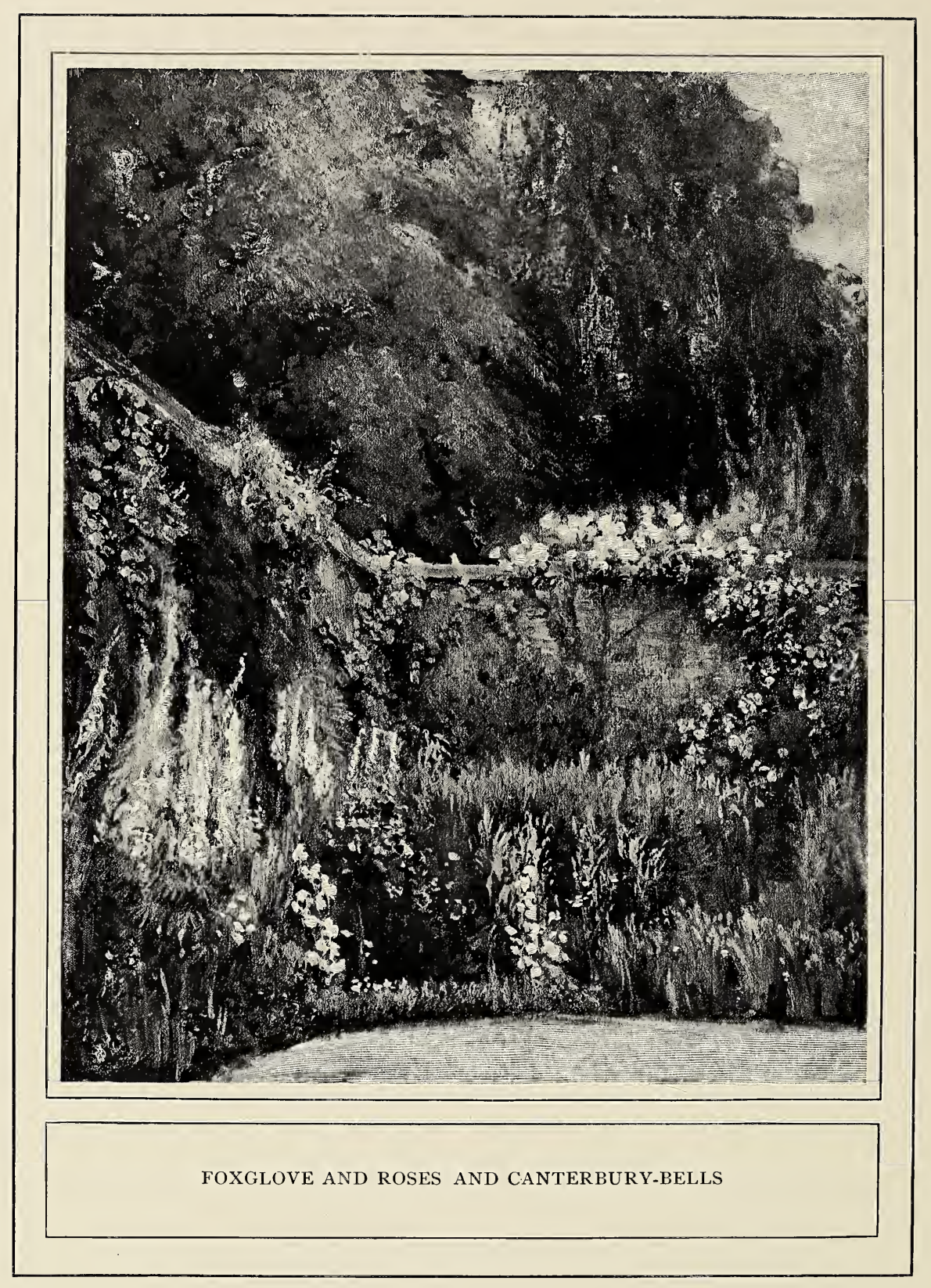




\section{INTRODUCTION}

picturing old parks and pleasaunces, historic spots where romance was as busy as history, where duchesses gave fêtes and powdered gallants occasionally fought duels; telling too of village merry-makings with old-time games and dances; of magnolia-planted southern places dedicated to hospitality, or northern gardens whose generous gift of posies or scarlet berry the utmost rigor of the weather could not wholly discourage.

In fact, the intention is to go wandering through many and many a lovely place of flowers and greenery, to show the most stately as well as the jolliest of garden ways, possibly to moralize a bit on the habits, the virtues, and the vices of garden owners, to point out a few famous gardens and relate a few old tales. Above all, to indicate how the social value of a garden is coming to be better understood and enjoyed here in America; how even a very small place is capable of yielding a vast deal of pleasure, and how the secret of thoroughly using a garden is one well worth the knowing.

The perfect garden should give something of its fragrance and beauty to the world at large, refreshing each passer-by with a glimpse at least of climbing flower and waving bough. But it must have hidden recesses known only to the favored; walls to keep it inviolate, shelter and peace and calm, or it is not really a garden. And now we will push open the gate. . . 

OUR GRANDMOTHER'S GARDENS 


\section{IN AN OLD GARDEN}

BY CHARLES BUXTON GOING

The garden beds are prim and square, Box-bordered, scenting all the air, And fruit-trees on espaliers crawl Around the high, old-fashioned wall.

Some little Mistress, long ago, Set out each straightly ordered row; She watched the spicy pinks unfold, The hollyhocks and marigold;

And standing in the poppy bed Is the old dial, where she read:

"Life is a Shadowe; soon 't is Night. Looke thou to God, thy Sun of Light."

Ah me! how many, many years Since Death dried all her mourners' tears, And mourners' mourners, one by one, Passed from the "shadowe" to the Sun!

But here her flowers portray her yet, Demure and sweet as mignonette, Tripping, beneath the arch of limes, To tend her posy bed betimes.

And where the sunlight lingers most, Musing, I sometimes think her ghost Breathes through the quiet paths, and dwells A moment by the foxglove bells.

A dainty, gentle ghost, that treads Light as the air around the bedsLight as the fragrant breath that blows The falling petals of a rose.

And when, although there is no breeze, A little whisper fills the trees And poppies bend their heads and stirI think they know and welcome her. 


$$
\text { . }
$$




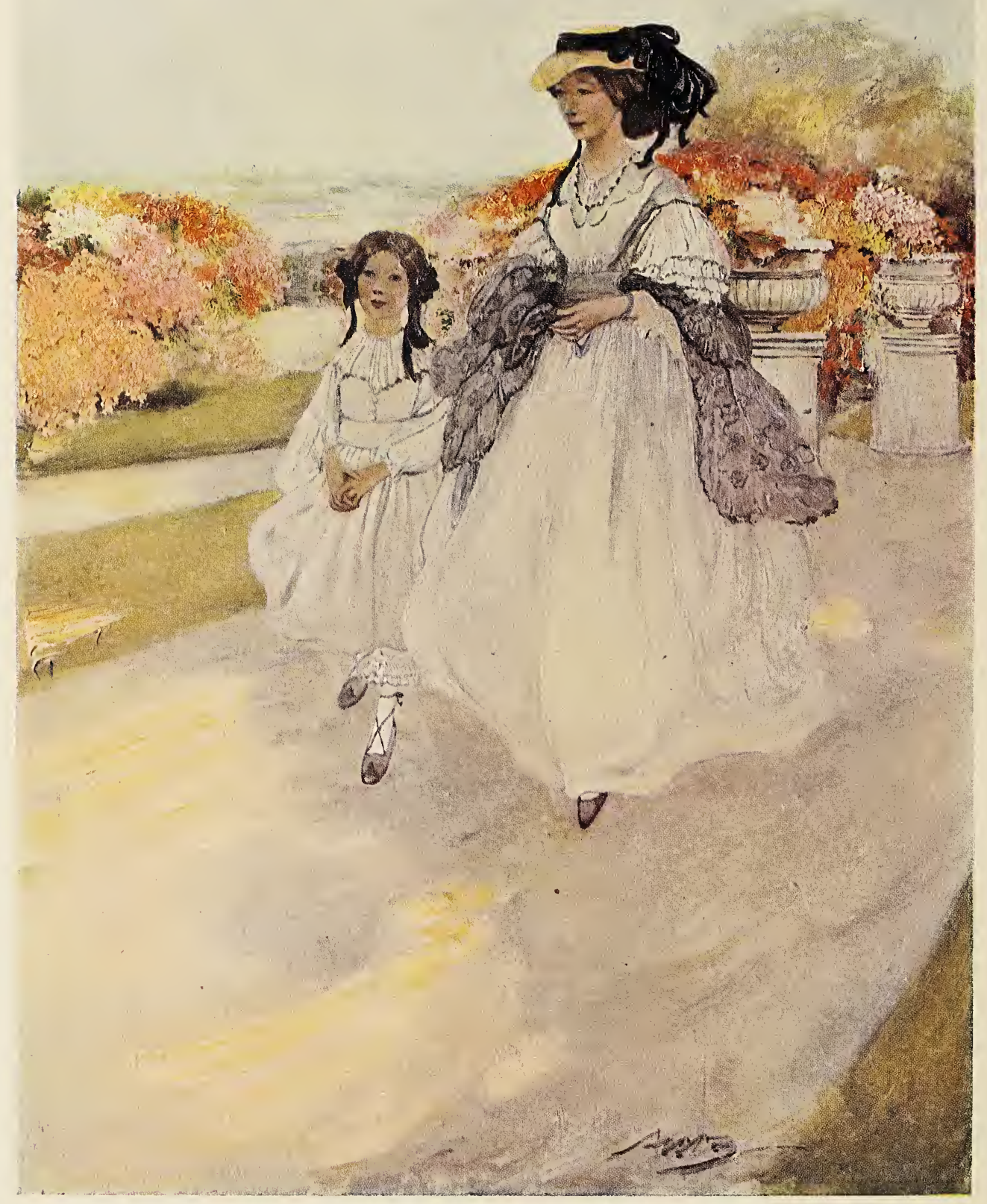




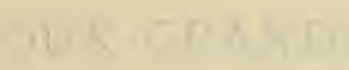

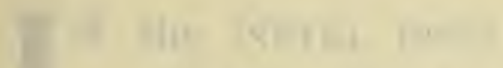

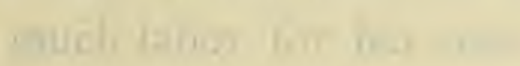

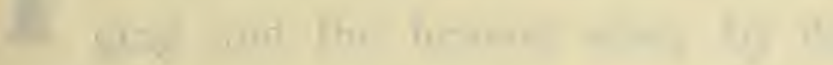

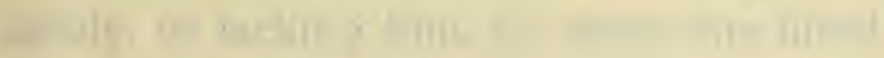

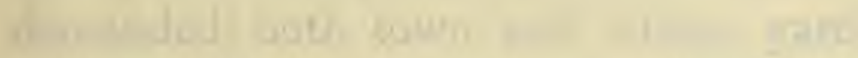

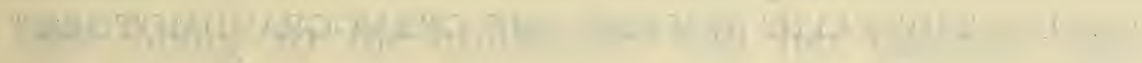

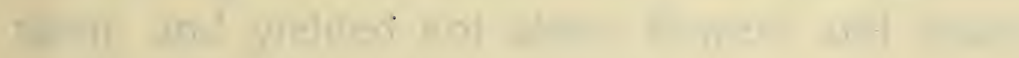

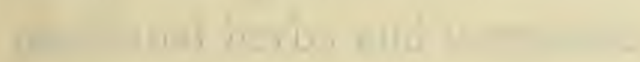

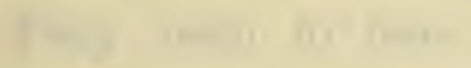

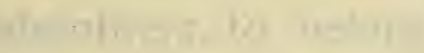

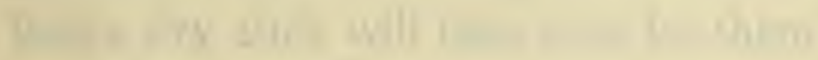

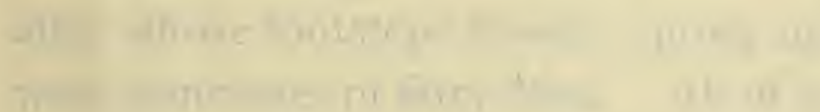

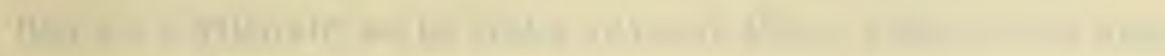

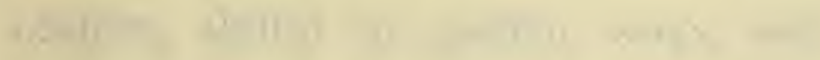
W1. M.

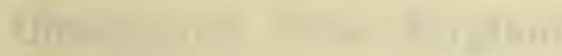

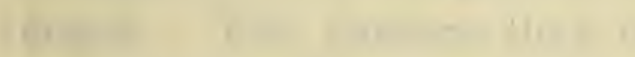
$=$ 
"ALONG THE PATHS WALKED THE GREAT-GRANDMOTHER." 


\section{ChAPTER I}

\section{OUR GRANDMOTHER'S GARDENS}

T $N$ the North, most of them were small; not too much labor for her own hands, aided in the digging and the heavier work by the man of the family, or lacking him, by some one hired as occasion demanded; both town and village gardens that owed their being to the housewife, had her impress upon them, and yielded not alone flowers and beauty, but medicinal herbs and vegetables.

They seem to have had "green fingers," these grandmothers, to belong to those of whom it is said that a dry stick will take root, let them but plant it, and after whose footsteps flowers spring up, as though they were princesses of fairy-land. All of us, of course, were not so fortunate as to have, owned these plant-wise ancestors, skilful in garden ways, wise and gracious women, creating in the wilderness little places of delight. Nevertheless, there were many of them, as can be seen throughout New England, wherever the old houses remain. The gardens they made were not often the result of fixed plans or formal designs, but began close 


\section{THE LURE OF THE GARDEN}

to the house, embracing it with vines and sheltering it with flowering shrubs, to spread out as time and occasion served and the needs of the family increased. With the Puritans utility went hand in hand with beauty in the garden, and the box-hedged beds that grew savory or sweet herbs, small fruits or simples, looked quite as lovely to the gardener as the hollyhocks and primroses imported from England. Tomatoes, under the name of love-apples, were kept in the decorative portions and trained on ornamental trellises, being thought poisonous, while the southern wall was used as in England to ripen quinces and apricots against.

It was the old-fashioned posies, many of them new enough then, that were planted in beds and borders: gillyflower, love-lies-bleeding, snapdragon, purple loosestrife, guelder-roses, heartsease, foxglove, lady'sslipper, eglantine or sweetbrier, since run wild over the country. Roots of sweet violet were carefully carried all the long way from England, as was ivy and honeysuckle. They flourished famously in the new soil, disputing with the narrow paths their right of existence, rejoicing in color and sweet odors, speaking in each healthy bloom and twining tendril of love, of care and gentle humoring.

The Faiths, Phœbes, Patiences, and Contents, for the names of the women were as quaint as those of their flowers, most of whom had faced perils and bitter hardship for an ideal, had strongly individual charac- 


\section{OUR GRANDMOTHER'S GARDENS}

ters, and this individuality showed itself in their gardens. For of these, though they were fashioned of precisely the same materials and given approximately the same space, no two were alike. Their apparent formlessness was not lack of expression; on the contrary, it was the subtle expression of a living face rather than the steadfast stare of a statue. Like the houses and the furniture of the period, the gardens reveal taste. They were never pretentious. They were comfortable, livable. The arbors, covered with grape-vines, were close to the back door, easy of access, places where the mother might sit quietly over much of her work. The flowers were to be picked, some to fill the pewter bowls, others for making essences and waters, or to be carried to a sick friend.

Flowers first tended to become a major part of gardening in England during the seventeenth century, and it is to this we owe the fact that the notable flowers and shrubs of England struck root here so early. Neither Puritan nor Cavalier would leave the new glory behind, so that both the grim New England land and the more ardent plantations of the South were enriched with the flowers of the mother country, as well as with her corn and cattle.

Narrow and hard the Pilgrim fathers may have been; but at least in their wives' or daughters' hearts the love of beauty lingered, and found an outlet in the garden; rose, larkspur, and stock feeding the secret springs of 


\section{THE LURE OF THE GARDEN}

sentiment as the peas and beans and cabbage fed the body.

There is something singularly touching to us of the present generation in these old gardens, as we find them now in the old towns, scarcely changed inside their high brick walls, and within whose circumscribed space so many frail and busy hands found joyful labor, so many patient eyes a calm delight. As the iron softened in the soul of the people and happiness and beauty were no longer regarded as sins, the utilitarian side of the garden was less insisted upon, fruits and vegetables were relegated to a place of their own, and the triumphant flowers gaily overran the spaces left vacant. This was about the hour that our actual grandmothers came in at the gate, and inaugurated the most charming era of the American garden. On the stern foundation prepared by their mothers, they laid a softening touch, breathed a more glowing summons over slip and bulb and seed, and were franker of their love.

In an ancient part of Salem, Massachusetts, two old maiden ladies occupy a commodious but simple framehouse that has altered little during the century and more of its existence. A strip of grass and shrubbery interpose between house and street, while to the left, over the palings, one can see the path curving round invitingly and plunging into the green depths beyond. Follow this path, and a charming old garden reveals itself. Cherry-trees and wistaria overarch it, disputing 


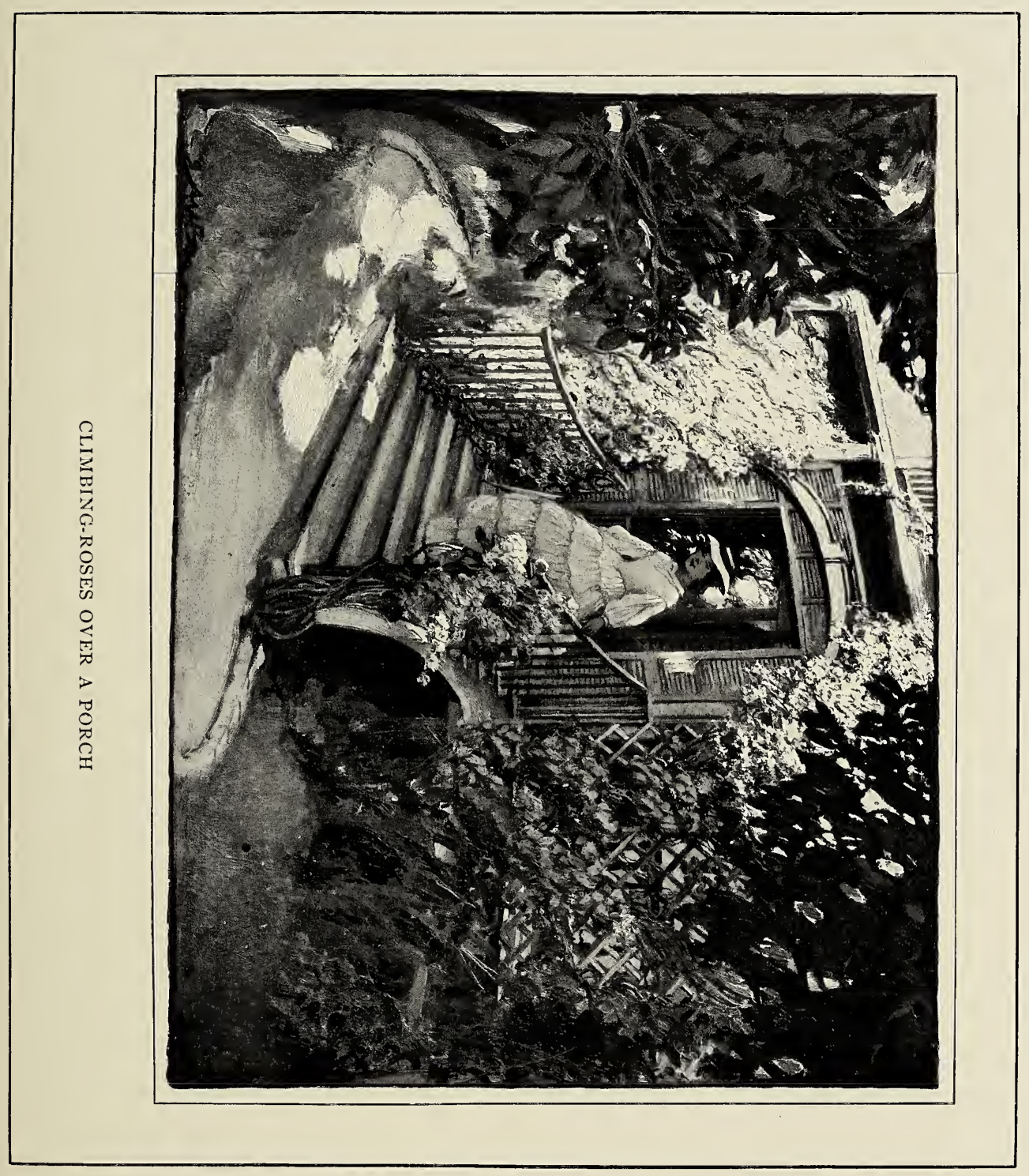





\section{OUR GRANDMOTHER'S GARDENS}

the dominion of the air, while on all sides the perennials, long since insurgent trespassers from the beds where they were planted, mingle their colors in an intoxicating jumble. Lilies of many sorts, white and purple and spotted ; tall pale larkspurs and canterburybells, and bachelor's buttons running the gamut of blue from white to indigo. Candleberry, smoke-bush, snowballs jostle the roses that take refuge on the roof of the summer-house and porch, and in and out of the fence. Myrtle, or periwinkle, with its geometrical flowers of sober blue and its polished leaves, scrambles everywhere, and from odd corners stocks and spice-flower send their sweetness. All the old-fashioned sisterhood, in fact, wander as they will within the precincts of this garden. The old wooden benches stand comfortably under the trees, beyond whose shadow the sun steeps his rays in the tangled color; a languid, murmurous hum from bee and beetle accentuates the silence, a gentle, interested silence, as of old days brooding over the place, musing of past events.

Hither came Hawthorne in his youth, escorting his cousins back from some evening sociable with shy courtesy. "He had not much to say, but his silence never made you feel uneasy," the younger of the two sisters will tell you, going back to her girlhood with a smile. "Perhaps he was àlways a little relieved to say goodby at the gate, however. But he liked to spend an 


\section{THE LURE OF THE GARDEN}

hour or two in the garden, and we used to leave him to wander about there by himself, smelling at the flowers or eating the fruit in its season. At times he would stay out there an entire afternoon, hidden from sight among the bushes, or, if any of us did cross his path, smiling silently and looking very content. Later on, he used to bring his wife, and while we were getting tea we could hear them laughing and chatting. He loved flowers, I think."

The garden was trimmer in those days, and the old ladies young. But the green old age of both is very sweet, very peaceful, and the spirit of a vanished day is still incarnate there.

New England had its big places too. There is an ancient garden in Sharon, Connecticut, that began to take shape as soon as the Revolution had ceded to peace. The fine house, high and broad, high enough to admit a world of sun and air, broad enough to produce a sense of brooding tenderness, the sense of home; the terraces, the orchards, the fish-ponds, many of the flowering trees and shrubs, remain much as they were, except that the honey-locusts have grown gigantic, and the lilacs and syringa look in at the second-story windows.

A tall, green fence of palings whose tops are cut into a clover-leaf shape protects the place and sequesters the garden proper from the fields and lawns. In the past this terraced portion covered two acres, planted with 


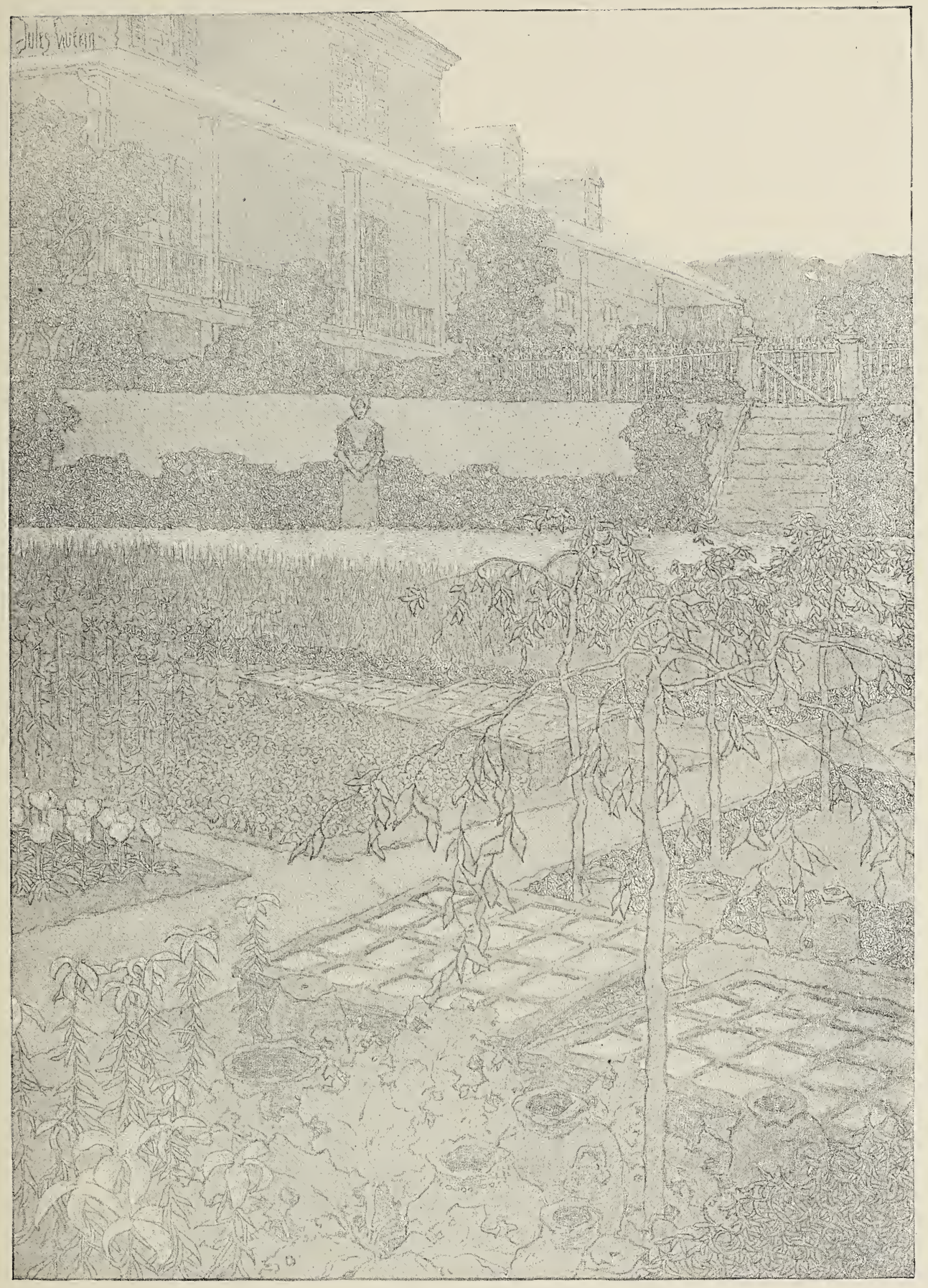

SQUARE TERRACES STEP DOWNWARD FROM THE HOUSE 



\section{OUR GRANDMOTHER'S GARDENS}

both flowers and vegetables, but it is smaller now, and the vegetables have been banished. The ponds are connected by a riotous brook, reached by way of a broad walk bordered with rows of brilliant annuals on either side, and almost entirely overarched at one time by superb shrubbery, since dead. The path ends just where the brook escapes from the first pond in sprayey falls, and there an arbor buried in honeysuckle and guelder-roses shelters seats for the weary or the idle.

The square terraces step downward from the house, divided into many beds by box-bordered paths. In the great-grandmother's time, there was in one corner the garden of herbs, and a huge asparagus bed, a new thing then, as well as many vines bearing white or purple grapes, from which wine was made during the fall days. Some of the old flowers still linger in the borders, such as valerian, marvel-of-Peru, and moss-pinks. But where the asparagus grew the daffodils and jonquils, nowadays spread a carpet of gold. The solid, fine nobility of the house and grounds, their effect of space and permanence, and old-world, courteous bearing remain unchanged, however; are, indeed, accentuated by the lapse of time.

Along the paths, wearing a great leghorn hat on her high-piled hair, and in a gown of brilliant flowered chintz, walked the great-grandmother, then a young bride, superintending the work of servants and slaves, keeping careful watch on everything, and noting the 


\section{THE LURE OF THE GARDEN}

varying occupations of days and seasons in her diary. The wine-press at work, herbs gathered and dried, "a busy morning in my Still-Room," where cordials and waters were distilled or expressed, the planting of this and that, particularly the making of that famous asparagus bed, which she watched from a camp-stool under a willow, carrying an umbrella and wearing galoshes, "for it was wet after last night's downpour."

In the South a different mode of life evolved another sort of garden. Gardens more like the great old English places, but more glowing, more luxuriant. The work was done by hosts of slaves, and room and money and inherited luxury were the rule rather than the exception. The accumulated taste of generations sought its expression in these southern gardens, and a touch of stateliness marks them. Much thought and study was given to laying them out, and landscape artists were brought from abroad to assist in designing them.

Coldstream Plantation, in South Carolina, is an ideal garden of this kind, and remains almost perfectly what it was, improved and enriched by its century of green security. A wonderful repose lies like a holy spell upon the place, a blessed sense of peace belonging both to house and grounds. The house brings to mind the line of the old poet,

May I a small house and large garden have,

for small and simple it is compared with its garden, 
"HERSELF AS LOVELY AS ANY FLOWER THAT GREW." 


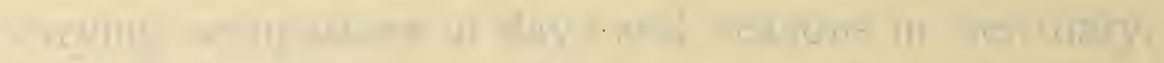

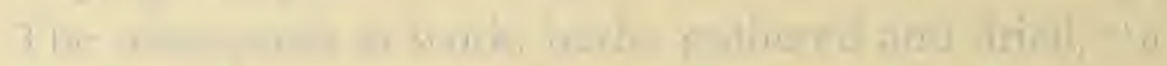

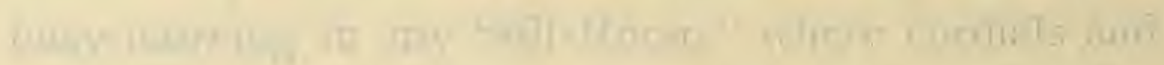

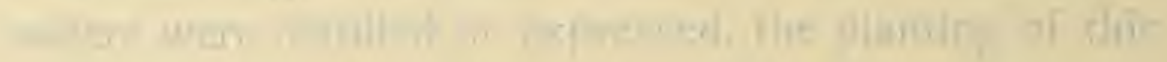

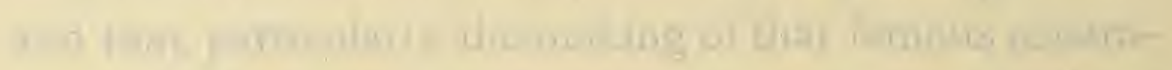

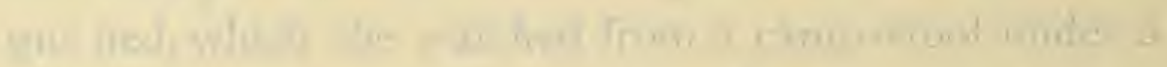

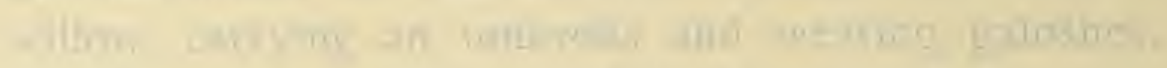

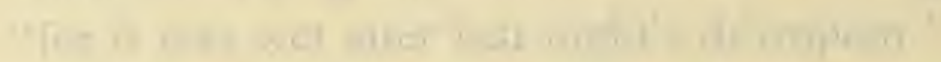

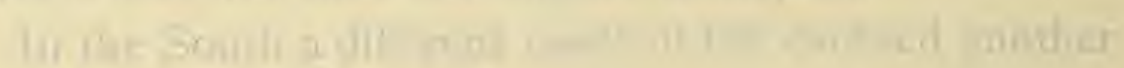

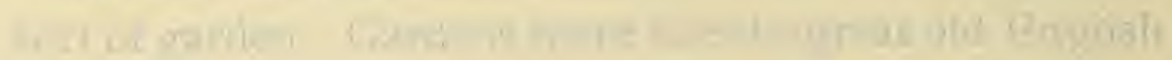

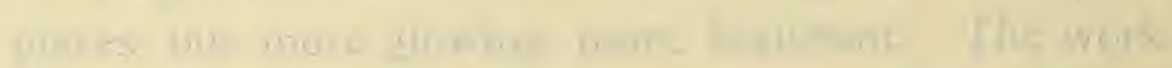

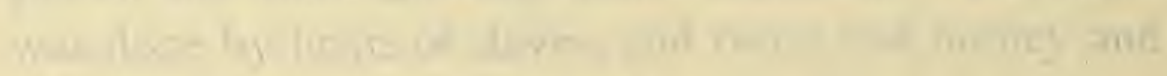

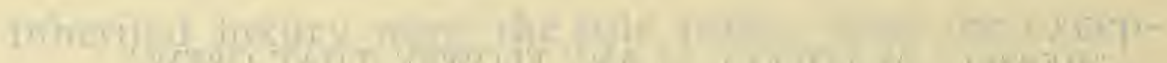

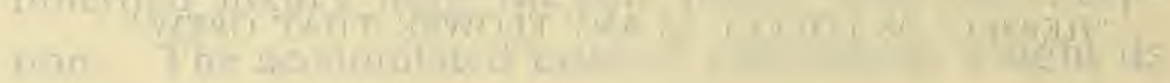

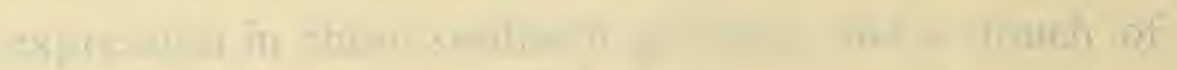

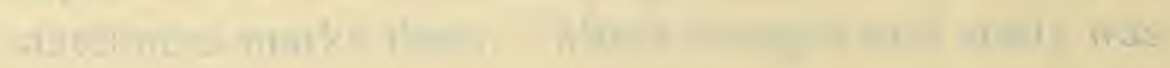

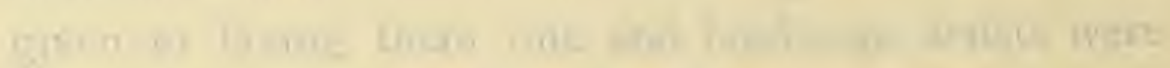

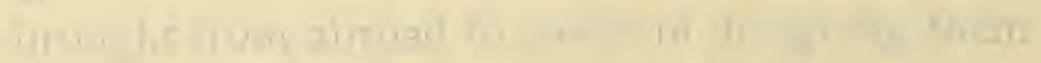

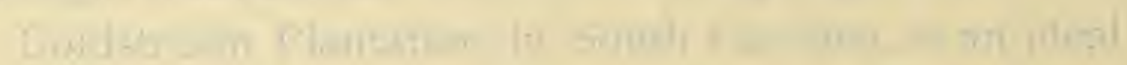

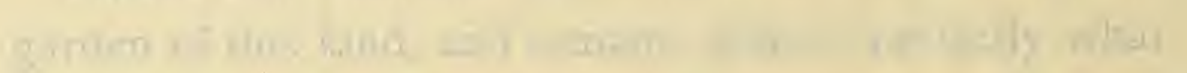

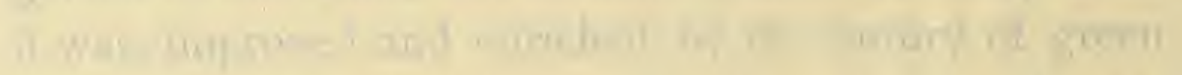

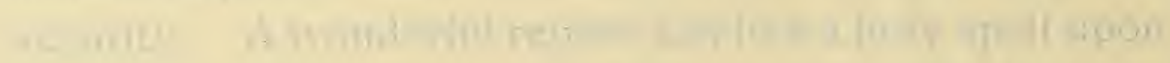

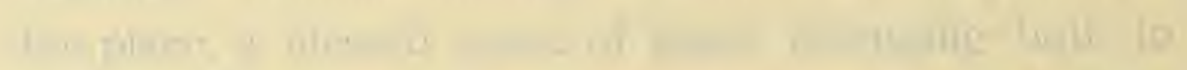

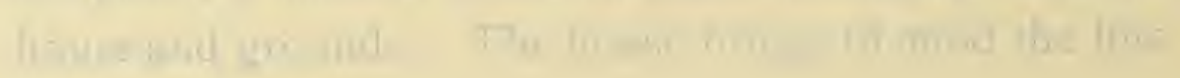
1. Whin wian pouc

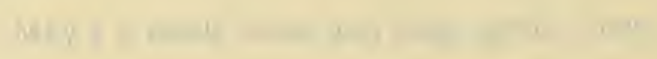

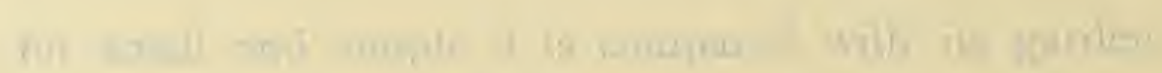




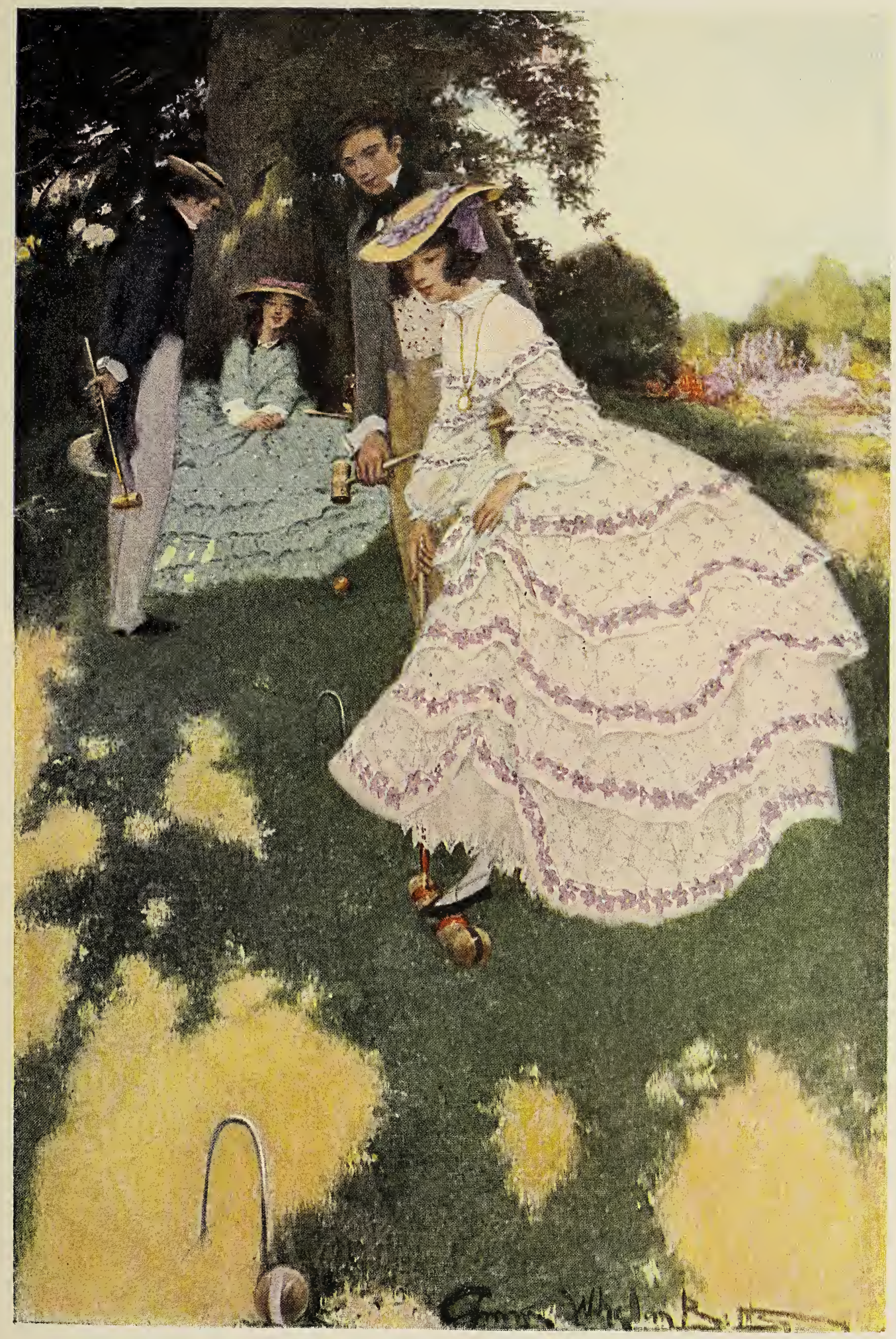





\section{OUR GRANDMOTHER'S GARDENS}

though large enough to make a home for a goodly family.

The hedges of Coldstream are perhaps its greatest beauty. They are of various kinds, but unusually fine of growth and shape. Ancient box, smelling good in the hot sun, and smooth and solid as though carved out of blocks; cedar and oleander, mock-orange and arbor-vitæ, twice as high as a man's head; cherokee rose, evergreen trimmed into immense arches, and holly. These hedges encircle the whole garden, and divide it furthermore into various sections, each given over to special loveliness or important uses. Thus the rose-garden, the tea-house, the children's playground, are all magnificently framed. But the preponderant beauty of the hedges does not prevent the rest of the garden from being wonderful. It blooms the whole year round. In January come the violets, white and purple and fragrant, the hyacinths and crocuses, and little flowers with lost names, rarer nowadays than those called rare. February brings the yellow jasmine that flowers before it leaves, and in the sun-warmed corners tulips and narcissi shake out perfume on every wandering breeze. The plum blossoms wreathe their snow upon the boughs, the Chinese almonds grow subtly sweet and lovely, while before the month has fairly merged into March, the gay company of daffodils are nodding in the wind and the dogwood flings wide its snowy banners. With March forsythia weaves a mist of 


\section{THE LURE OF THE GARDEN}

gold, and many-colored irises make rainbow festival, while the forest-trees turn suddenly green and rose.

But wait for April, and then walk down the luring path between the lofty hedges to the northeast corner, where the garden touches its apogee. Behind the Chinese almonds the tea-arbor shelters gaily, and between this arbor and the house the path separates in all directions, making geometrically shaped beds that are filled with color. Here the spiræa hangs its drooping fronds of flowerets and the magnolia blooms magnificently. The creamy banana shrub steeps the air with its heavy scent, white and pink diervillas, lilacs in bewildering variety and honeysuckle tumble into flower - and then, some sudden day, the azaleas blaze into flaming color, so radiantly glorious as to be entirely unbelievable, except that there they are. Towering high overhead in swelling masses, scattering vivid petals on grass and gravel, all in sunset hues of rose and pink and crimson, yellow and cream and warm white, unforgetable, amazing.

Next come the intense crape-myrtles, the syringa, waxy-white, and the roses, of every color and size and shape. Gardenias come with the sweet-peas in May, and then, too, the oleanders turn both pink and sweet.

Month by month, hidden in its encircling hedges, the garden brings its various blossoms to perfection. Even in December it has roses and camellias to show, while the autumn days are intoxicating with late lilies and 


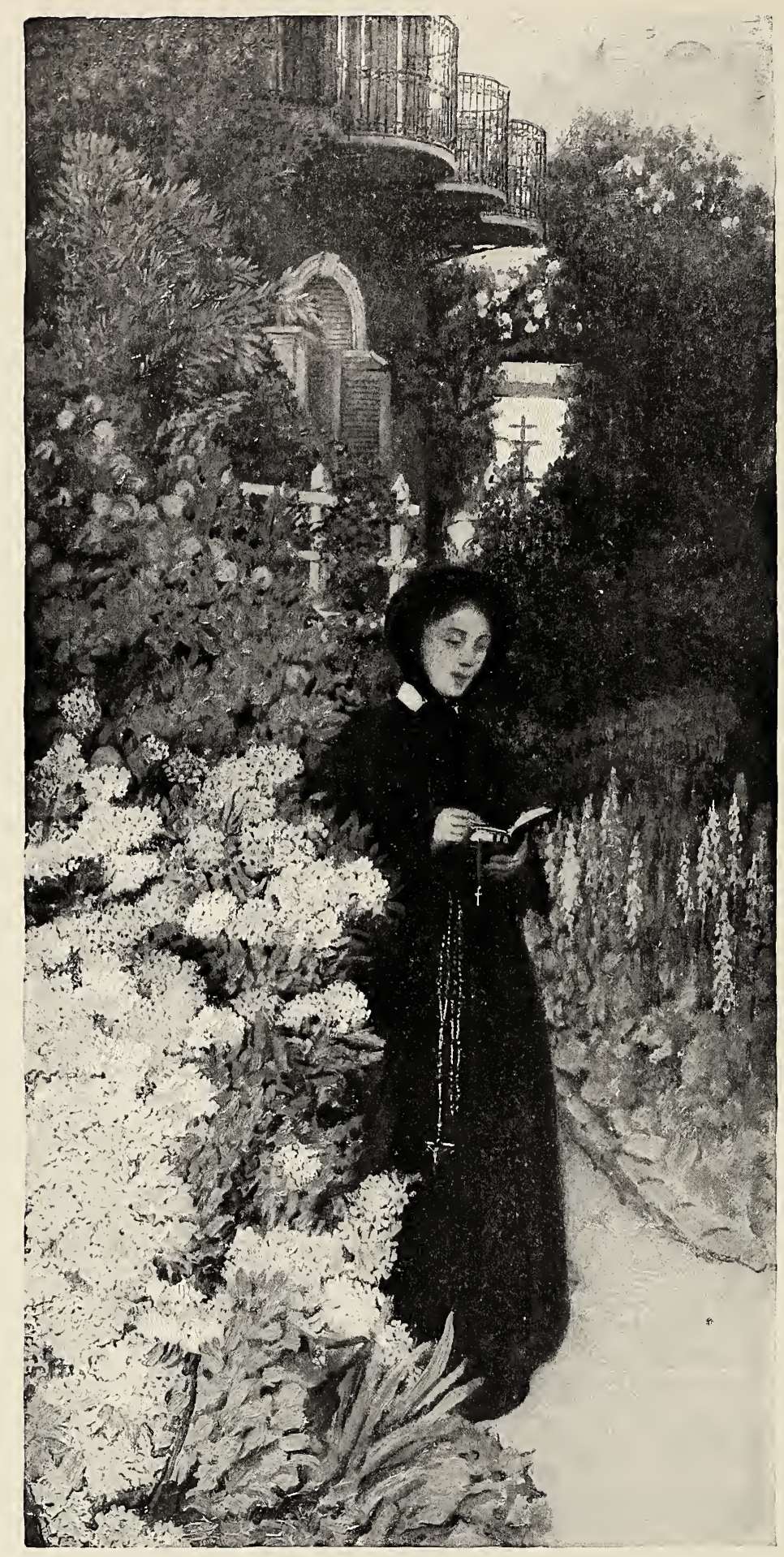

A CHARLESTON GARDEN 


\section{OUR GRANDMOTHER'S GARDENS}

tall dahlias and the fire of the dying leaves. It was early in 1800 that Robert Witherspoon brought his bride home to the simple white house and great garden, telling her she was lovelier than any flower it grew. And ever since the garden has been cherished and enjoyed.

But all the southern grandmothers did not live on estates. There were town dwellers there, as in the North. Perhaps Charleston has retained the gardens they made in their original perfection more surely than any other of the old cities, those high-walled gardens of ante-bellum days, whose builders were full of the traditions of seventeenth-century England and France, when gardens grew divine.

There is, for instance, the Miles Brewerton House, with its walled garden. The house is a fine type of the early Georgian with brick-arched loggias overlooking the space of flowers, that stretches north and south. Down the center goes a wide pathway, overarched by an arbor completely covered with the twining branches of one gigantic climbing rose. The flower beds extend on either side, brick-edged and bordered with sweet violets and other small and fragrant plants. Close to the house the oleanders and acacias bloom and crowd, and vines are all about, clambering over porches and walls and trees. So secluded it is that the wild songbirds come here to nest, careless of the city close around. 


\section{THE LURE OF THE GARDEN}

These high brick walls are characteristic of Charleston's gardens. They are various in design, relieved by elevations and blind arches, by small turrets and square ends. Often they are entirely hidden under the English ivy, or softly pink from long standing in sun and rain. Some are coped with stone. All lend magic glimpses of the wonderlands they shelter, through an arched gateway or unexpected opening, or by spilling over a shower of wistaria or laburnum. But these places are essentially town gardens, made to lend seclusion and quiet to the house, as well as loveliness, and to be lived in as part of the home. They are lovable, discreet, and sequestered, nor are they entirely selfish. For down the steps and beside the porches, over the walls and through the lattices, the flowers give every passer-by hints and promises and prophecies, no full revelation, but exquisite glimpses. Charm is the keynote, and the perfect relation of house and garden each to each, and both to their owners' needs, whether of body or soul.

Surely our grandmothers of the North and the South, working in a new land and under strange conditions, left us a worth-while heritage in these posy beds and garden closes of theirs, a heritage whose value we are growing to appreciate, and whose example we shall do well to imitate. 


\section{WASHINGTON'S GARDEN}




\section{MOUNT VERNON}

WRITTEN AT MOUNT VERNON, I 786

BY DAVID HUMPHREYS

By broad Potomac's azure tide, Where Vernon's mount, in sylvan pride, Displays its beauties far,

Great Washington, to peaceful shades, Where no unhallowed wish invades,

Retired from scenes of war.

To thee, my friend, these lays belong: Thy happy seat inspires my song,

With gay, perennial blooms,

With fruitage fair, and cool retreats, Whose bowery wilderness of sweets

The ambient air perfumes.

Here Spring its earliest buds displays, Here latest on the leafless sprays

The plumy people sing;

The vernal shower, the ripening year, The autumnal storm, the winter drear,

For thee new pleasures bring.

Here, lapped in philosophic ease, Within thy walks, beneath thy trees,

Amidst thine ample farms,

No vulgar converse heroes hold, But past or future scenes unfold, Or dwell on nature's charms. 



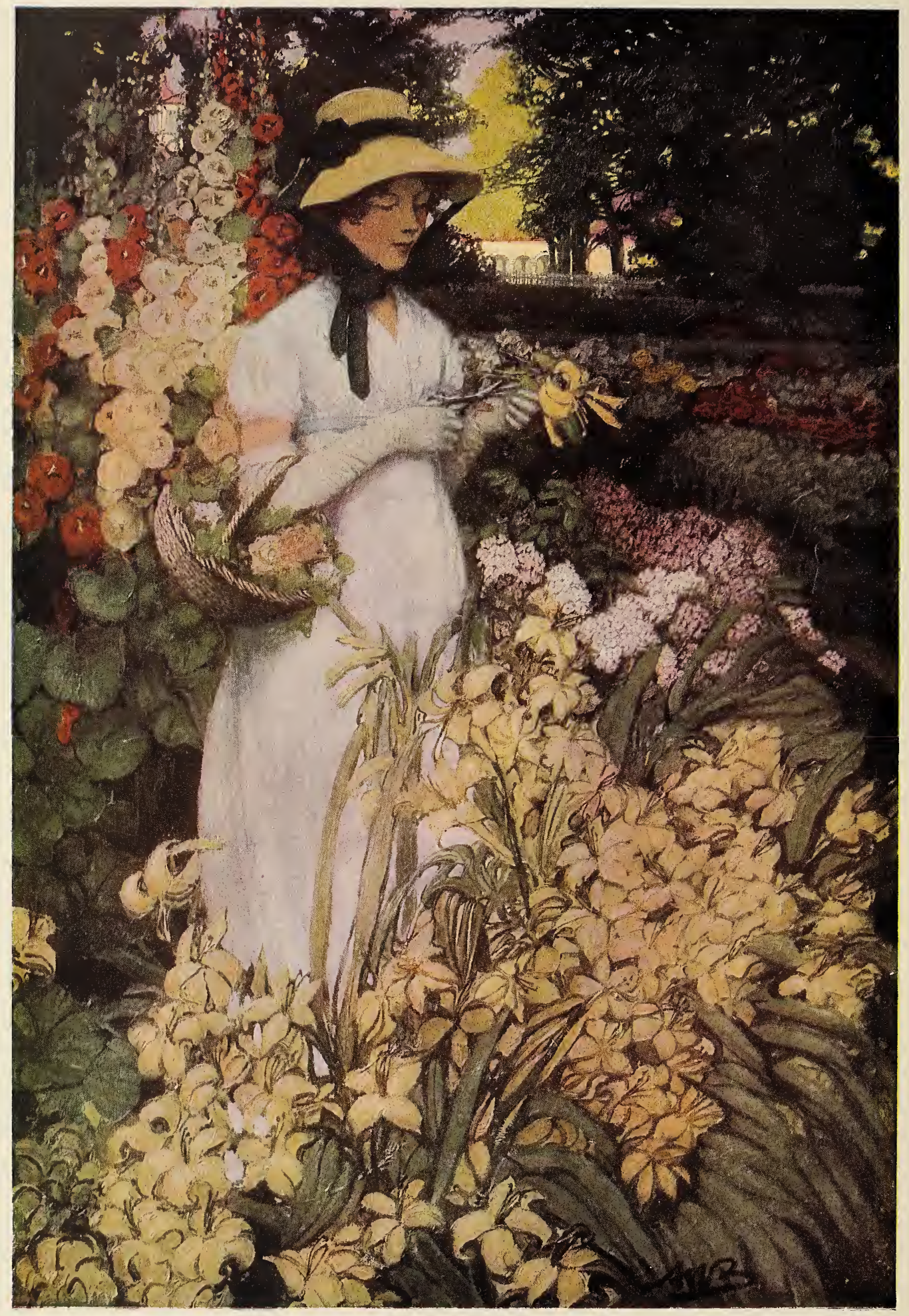




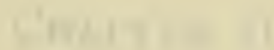

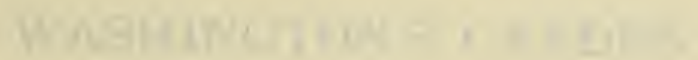

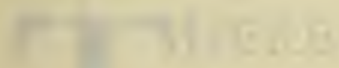

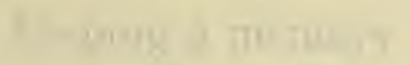

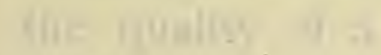

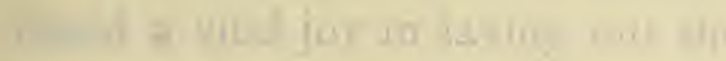

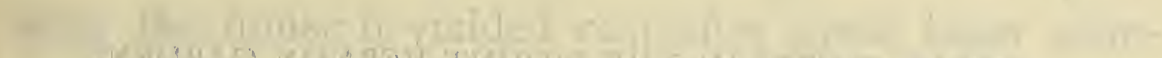
What

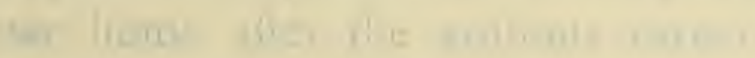

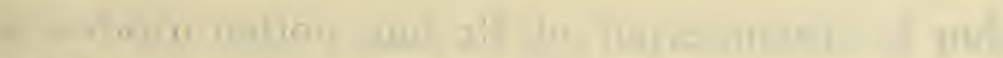

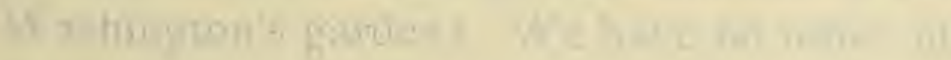

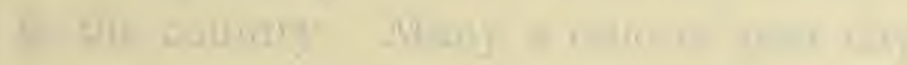

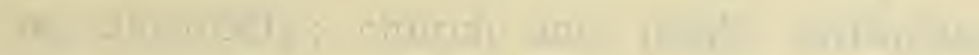

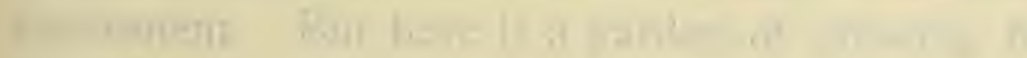

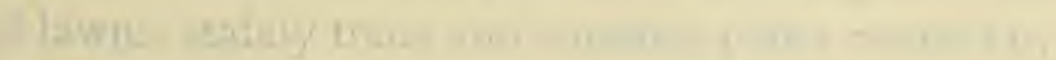

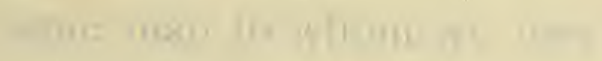

ing he it ingtion the

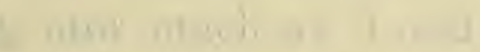

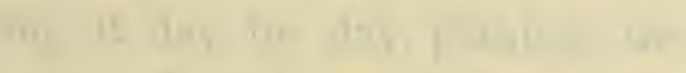

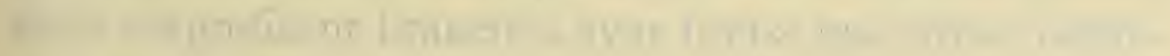

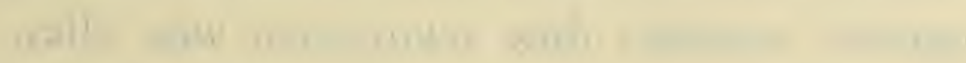

나나 Linf 
NELLY CURTIS IN THE MOUNT VERNON GARDEN. 


\section{Chapter II}

\section{WASHINGTON'S GARDEN}

THERE is a garden in America that has in its keeping a memory so hallowed as to lend it

1 the quality of a shrine. To the man who found a vital joy in laying out the grounds and planning the house it yielded rest after great labor gloriously performed, peace after the tragic violence of years of war, home after the arduous career of leader to a new-born nation and all the harassments of public life.

Washington's garden! We have no other place like it in the country. Many a relic of past days remains to us, assuredly; church and tomb, birthplace and monument. But here is a garden of growing flowers, broad lawns, stately trees and winding paths created by the same man to whom we owe a new ideal of patriotism and the foundation of our being as a nation; looking now much as it did when he lived here, improving it day by day, planting the trees that spread their magnificent branches over house and drive, building the walls now overgrown with climbers, finding time to superintend everything, from the rotation of 


\section{THE LURE OF THE GARDEN}

crops on the farms belonging to the estate to the care of the rare exotics in the large greenhouses.

The situation of the house on the gentle rise overlooking the river and the blue hills of Maryland is a fine one. It is spacious, dignified, and simple, like the mind that perfected it, having balance and nobility of character, together with a satisfying harmony. It is, indeed, a visible incarnation of Washington's spirit, even to a certain sternness and precision in the original plan, softened and mellowed by passing time and the green growth of nature. The house and garden are intimately associated, making between them the home. There are no formal beds of variegated leaves distributed like the pattern on a quilt about the lawn, but the grass flows from the columned veranda in a broad expanse toward the Potomac, exquisitely diapasoned with the moving shadows of the trees and bordered by irregular masses of flowering shrubs. The hand of the soldier is manifest in the planting of the trees, and though there is precision, there is no pretension. It is not a show estate, but a dwelling to be loved and lived in, and to welcome friends to. Even the hosts of sightseers who throng to it in the hours given over to the public cannot dissipate this salient characteristic. Gently serene, the place appears to be awaiting the return of its master, faithfully fulfilling its seasonable tasks, but changing little with time. The broad sweep of the driveway, the approaches to the stream, the long wind- 


\section{WASHINGTON'S GARDEN}

ing paths and framed vistas are as Washington planned them. His, too, the prim box-hedges and such of the walls as remain. Behind the greenhouses, in the past, stretched the long straight rows of flowers where Mrs. Washington gathered basketsful of blooms for the house; here, too, were her savory herbs, and a bush or two of lavender.

Very lovely the old wall is now, with its soft tones of gray and rose and cream, where the shrubbery reaches high, lifting its blossoms above the coping. The paths are bordered with narrow beds of flowers, and there are many other straight long beds that are a mass of color and fragrance, and vocal with the hum of bees.

Contemporary letters and sketches give many a view of the General, clad in sober drab costume and widebrimmed hat, riding or tramping about the estate. Judging from notes in his diary and letters of his own, he was far more interested in the fields and farms than in the flower garden proper. Nevertheless, he notes on a certain January IO, that "The white-thorn is full in berry," and also remarks that he has been planting holly. Beyond much doubt, however, it was Martha Washington who had the chief care of the more decorative part of the homestead. She it was who filled the beds with seeds and roots in the spring, and cut the fresh flowers, or clipped off the faded ones in summer. That was woman's work, and though the General was fain to wander among the roses with a keen pleasure in 


\section{THE LURE OF THE GARDEN}

their beauty and sweet smell, he left their care to his wife.

In a corner there is a certain old white rose-bush that tradition, in the voice of the caretaker, informs you is the identical one beside which lovely Eleanor Custis plighted troth with Lawrence Lewis, the preux cavalier of his day. Nor were these lovers the last to find happiness beside the fair bush. For tradition goes on to say that ever since the rose has proved a fatal spot for man and maid, and that many a happy pair first found courage to ask and to answer the great question as they paused to look at its burden of bloom. To-day, no more than in sweet Nellie's youth, can lovers resist the persuasion of the white rose-bush. Possibly some potent spell lingers in the perfume of its flowers, or the spirits of lovers now dead set other hearts to beating where theirs beat before. At all events, any couple who dread the chains of matrimony will do well to avoid the old bush, harmless and sweet as it appears to the eye in all the bravery of its June blossoming.

One likes to imagine that this bush was planted by Washington and his wife some wet spring morning, when the earliest-come birds were twittering on the budding boughs: planted with laughter and much argument as to just where it would look best, and finally set in its place by those strong hands behind whose capable power lay a heart not less warm with human love than noble with sublime faith in ultimate human 
THE OLD WATCHMAN ON HIS ROUNDS AGAIN. 


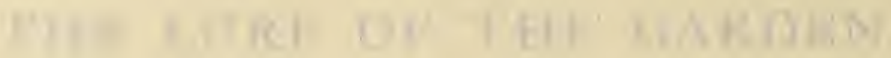

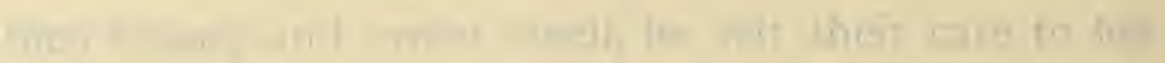

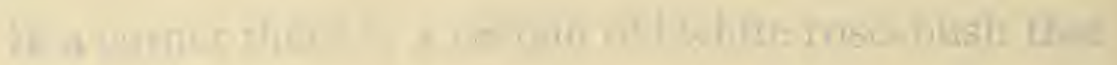

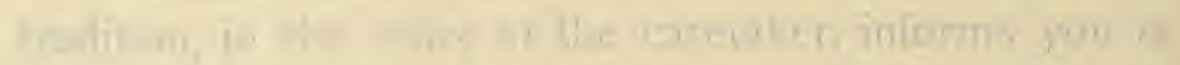

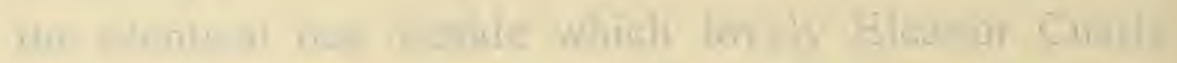

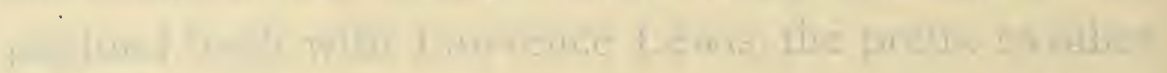

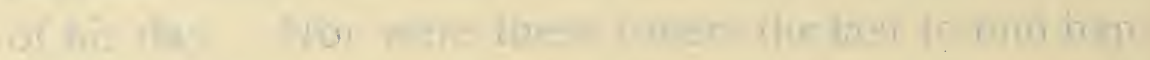

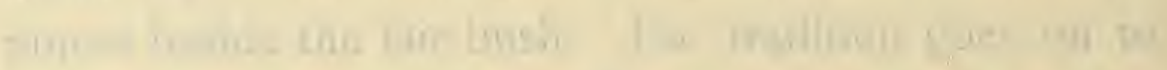

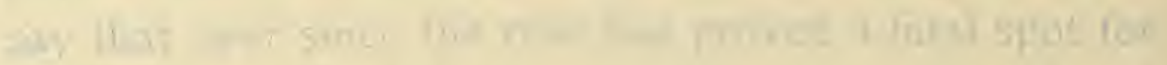

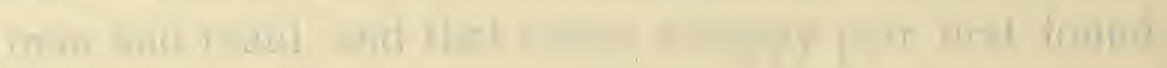

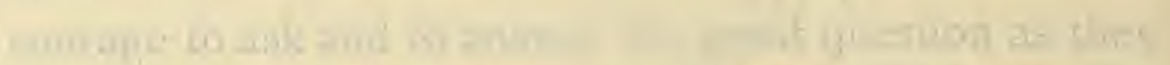

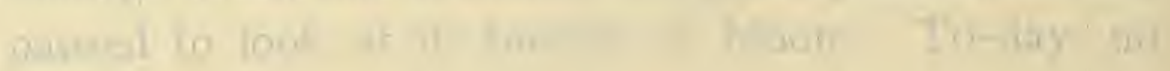

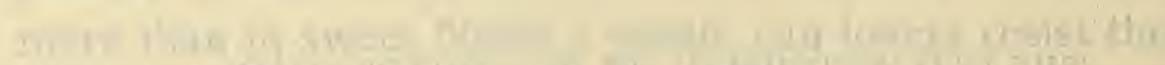

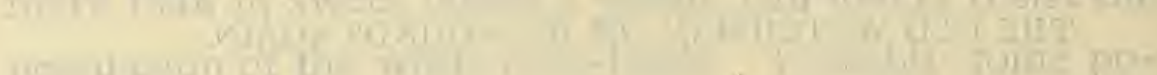

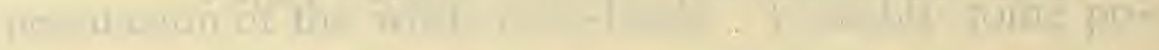

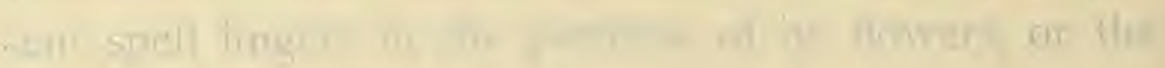

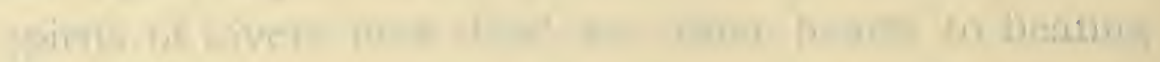

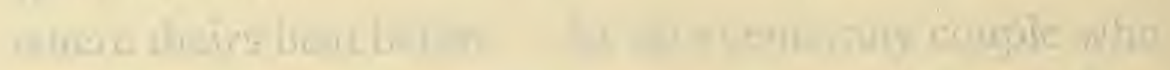

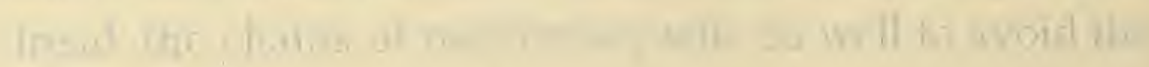

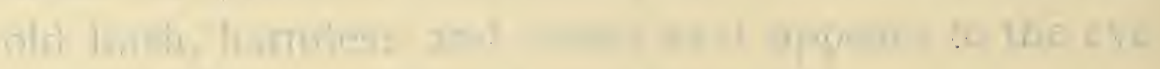

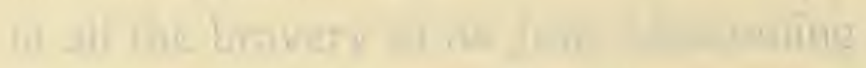

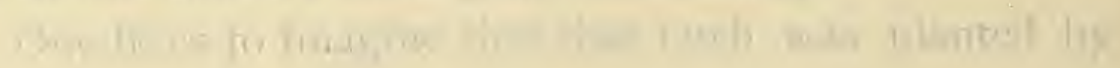

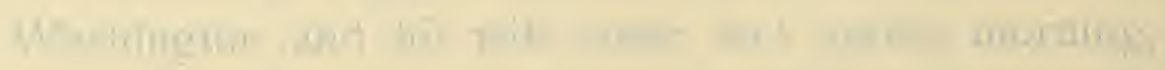

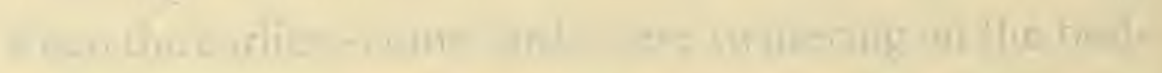

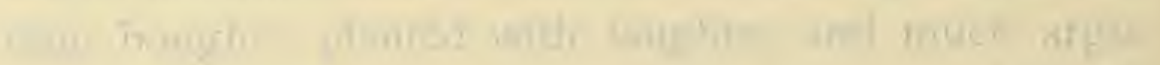

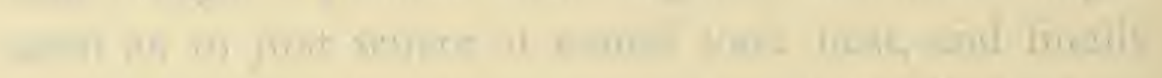

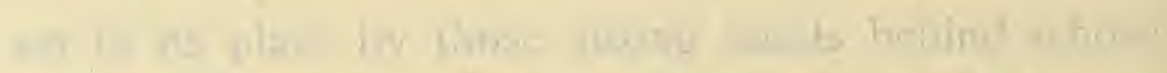

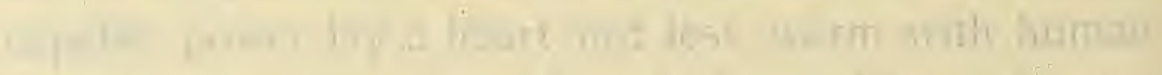

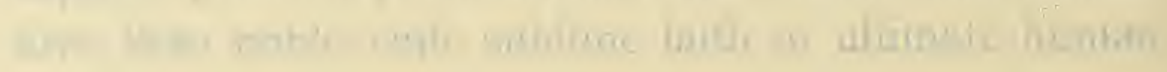
it 


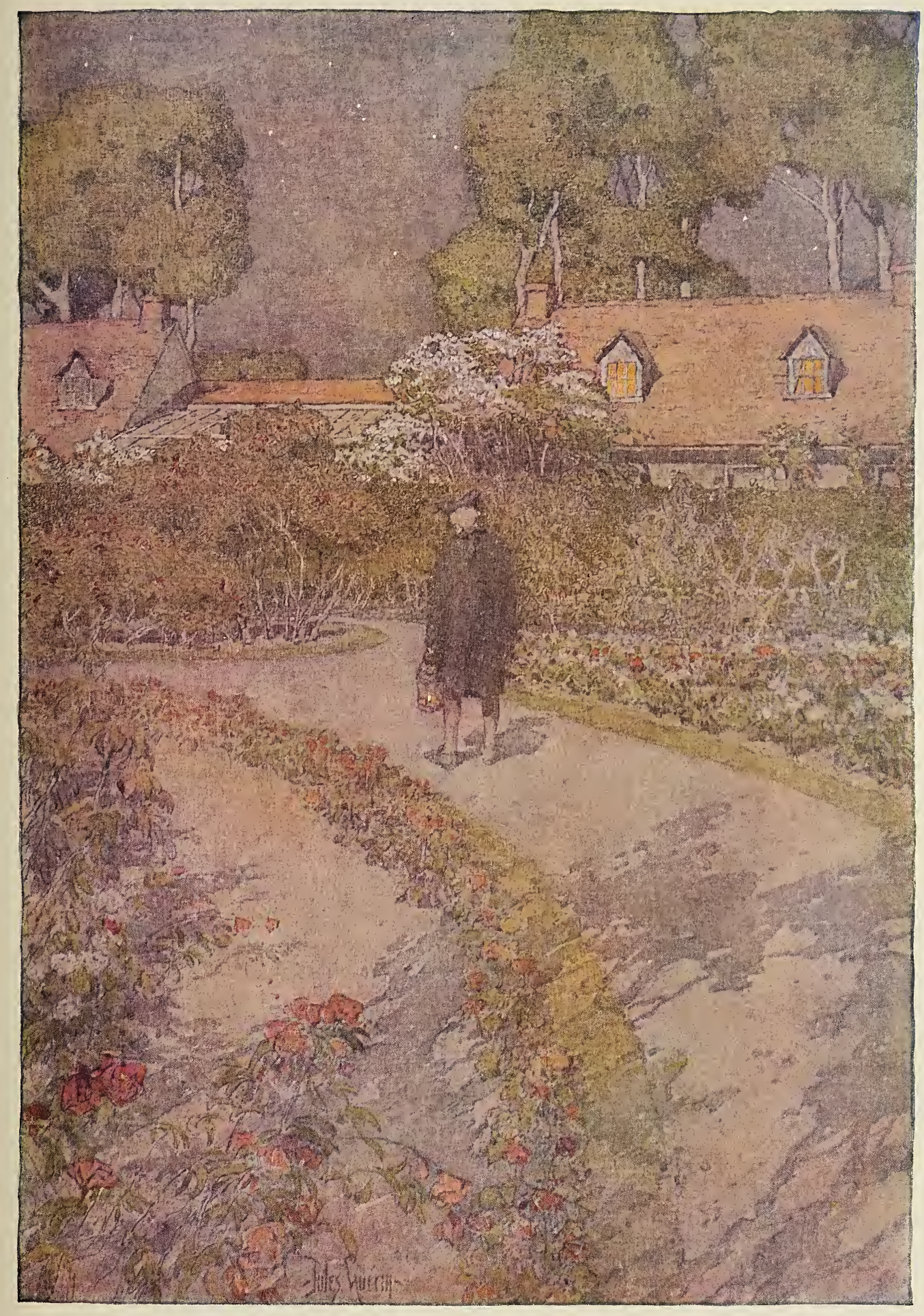





\section{WASHINGTON'S GARDEN}

good. Surely the white rose-bush, so planted, may well have acquired a quality beyond that of any other of its kind on earth.

A plan of the place as it was in Washington's day still exists. It was drawn in color by Mr. Samuel Vaughan of London, who visited the General in 1787 , and was approved by Washington, with the addition of a slight correction. The lawn and the two groves of trees in front of the house are the same to-day. Behind, the plan shows the small circular grass-plot surrounded by the driveway. Below this a large fiddle-shaped lawn extends, framed by trees in marshaled rows, and flanked on either side by the big kitchen-gardens. Close to the house were the numerous cabins for the slaves, the quarters for white servants, the tailor and bootmaker and blacksmith shops, etc. A spring-house, a smoking-house, stables, and spinning-rooms, even a school, all are arranged in symmetrical order. The kitchen-gardens were inclosed within brick walls, and a "stately hothouse" stood in one. Mr. Vaughan notes that the General "owned I2,000 acres, whereon were several farms, five of which are kept under cultivation. . . . He breakfasts at seven, then mounts his horse and canters six days in the week to every one, a circuit of about twenty miles, inspecting and giving directions for management at each, and returns home at two o'clock."

A charming country-gentleman's life. And while Washington rode forth over the estate, his lady gave 


\section{THE LURE OF THE GARDEN}

her orders for the planting of this and that in her gardens, saw that the paths were raked and the beds weeded, and sent word through her distinguished husband to thank a friend for the present of "roots and flower seeds." Probably Miss Custis moved about the sweet-smelling beds a good deal, vivid as a flower herself, on visits there. And the General's nephew, George, with his own wife, also dwelt in the "Delightful Mansion," going the rounds for his uncle when affairs of state called the latter away; for Washington was still needed by his country.

The best time in which to see this beautiful and kindly spot, and to conjure up its past, is when the long shadows begin to stretch themselves on the grass, weary of their dancing through the day. A mist lies white on the river, stealing up as the twilight deepens to creep among the trees and drift over the garden in wraith-like wisps. Gone are the excursionists with their noisy admiration; not a footstep . passes, at least no human tread. Instead there are scurryings of the little creatures of the earth and air, the chuchurr of myriads of insects, the evening song of birds in the rich gold and purple light of the dying day, the stirring of the wind in the trees. So many birds! The cardinal, fluting its joyous notes before it drops like a flame to the ground from the dark mystery of a huge oak; the song-sparrows and linnets, measuring their ripple of music over and over again; the robins calling from every tree-top; then, 


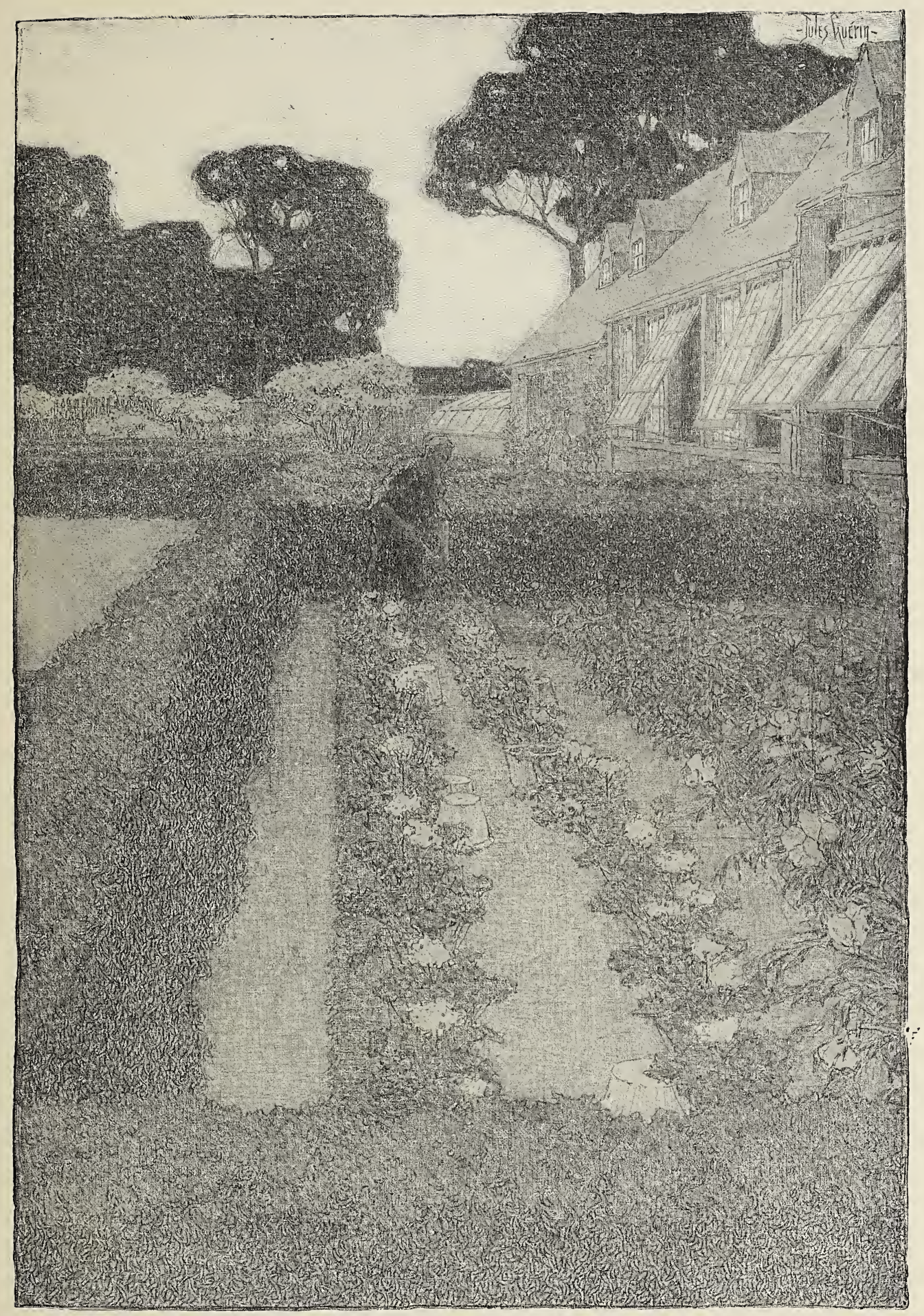

THE LONG, STRAIGHT ROWS OF FLOWERS 



\section{WASHINGTON'S GARDEN}

after the moon is up, the June night is sometimes flooded with the tangled melody of a mocking-bird, weaving its silver mesh of song after all the other singers have hushed their last notes.

Now the fireflies begin to gleam over the lawns and among the shrubbery. The shadows increase, and are full of the smell of honeysuckle. An exquisite blue haze rises and wraps itself about the tops of the trees, interposing an almost impalpable presence between the garden and the rest of the world. The moon shines white on the white house, sharply outlining the columns, and the night wind tosses the shadows about oddly. Murmuring with unseen life, moist and warm and fragrant, the garden waits. . .

Is it a shade among the shades? Or really a tall figure in a cloak, with a three-cornered hat giving a glimpse of nose and chin? It seems to bend over a white mist-form as though in converse. Now both move slowly toward the house. A deep quiet broods throughout the garden, a welcoming silence. Surely the two figures are those of a man and a woman; see, he lifts his hat and raises his face toward the light with a movement full of dignity and peace . . . or is it but the shimmering of a white lilac stirring to the breeze? Fancy, deceiving elf, has lost her power, or you your true seeing. At all events, the trees are swaying again, the insects busy with flute and viol, and the heavy lilies nod their heads indifferently. 


\section{THE LURE OF THE GARDEN}

It was, to be sure, the larger aspects of the estate that most interested Washington; he took to farming with the same energy and far more pleasure than he had to fighting. He utters wisdom on carrot and bean, and asserts that he has "a high opinion of potatoes." But, when the day's business was accomplished, the rounds made and directions given, with dinner comfortably over, it is pleasant to think of the country's father as having strolled between the flower-beds, smoking a long pipe perhaps, his hands clasped behind him, his eye quick to detect any neglected bush or plant, or any opportunity for improvement, and yet noting with delight the fresh growth and lusty flowering around him. In his mind, doubtless, old memories of camp and office mingled with the present whose fine fruit he was enjoying; much talk of past and future there must have been, as the old verses that preface this chapter tell, as well as pregnant remarks on the beauties of nature. Hither came the traveler from distant lands, to look upon the hero of a new epoch, living out the last, quiet years in such simplicity; and here, too, the great men who had helped him in his work, and the new generation that was to carry it on.

So let us leave him and his garden, moving softly away through the rich June night along the paths he trod; with a last look at that old white rose-bush, glimmering rather mischievously under the moon, meditating maybe upon its dangerous but delicious mission, 


\section{WASHINGTON'S GARDEN}

and scattering its petals in a magic circle about it; and just one more backward glance before we go, half-fancying we hear a slight commotion, as though the old watchman were on his rounds again. ... 



\section{CHILDHOOD IN THE GARDEN}




\section{THE FLOWERS}

BY ROBERT LOUIS STEVENSON

All the names I know from nurse:

Gardener's garters, Shepherd's purse, Bachelor's buttons, Lady's smock, And the Lady Hollyhock.

Fairy places, fairy things, Fairy woods where the wild bee wings, Tiny trees for tiny damesThese must all be fairy names.

Tiny woods below whose boughs Shady fairies weave a house; Tiny tree-tops, rose or thyme, Where the braver fairies climb!

Fair are grown-up people's trees, But the fairest woods are these; Where if I were not so tall, I should live for good and all. 
. 


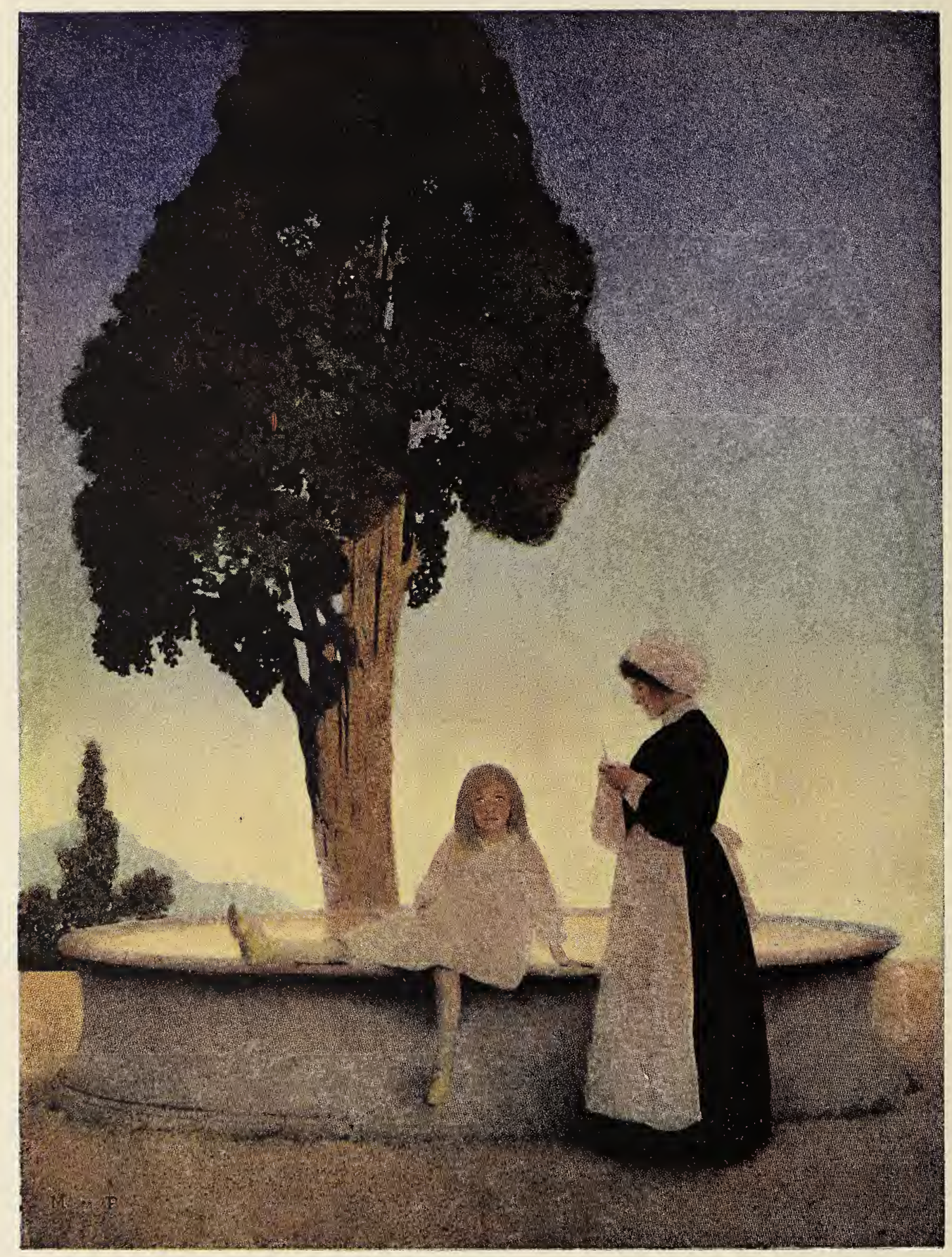




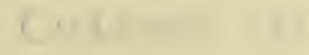

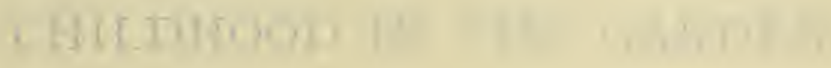

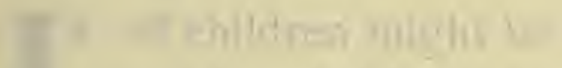

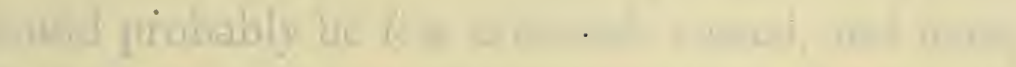

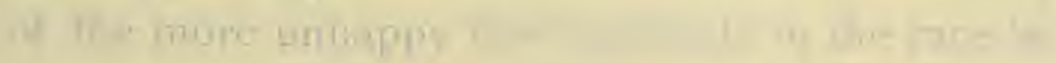

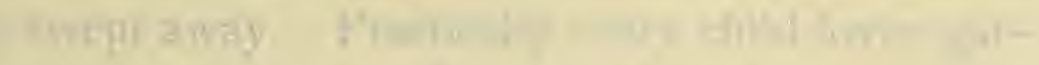
wess figgong an the

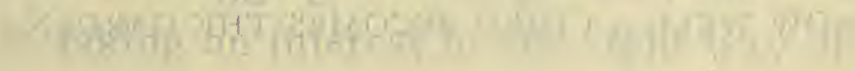

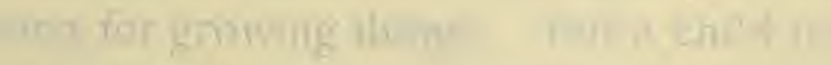

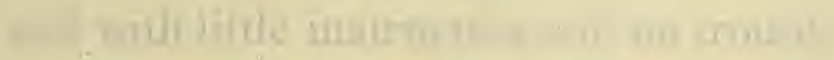

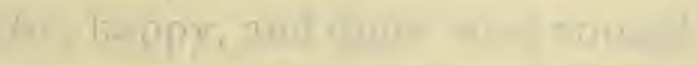

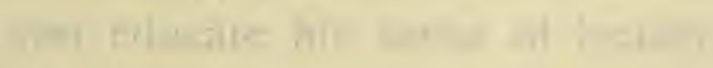

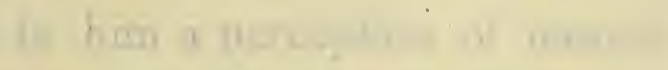

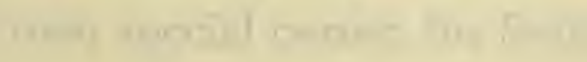

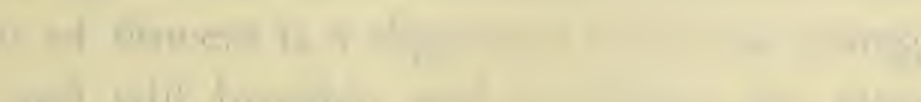

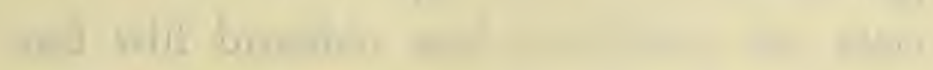

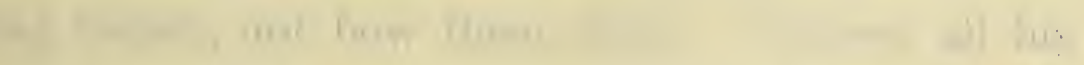

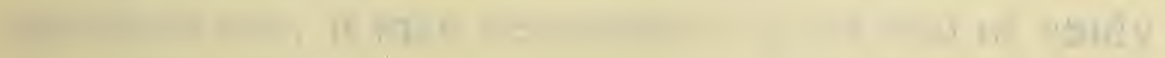

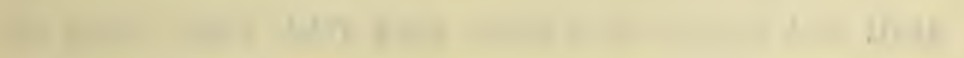

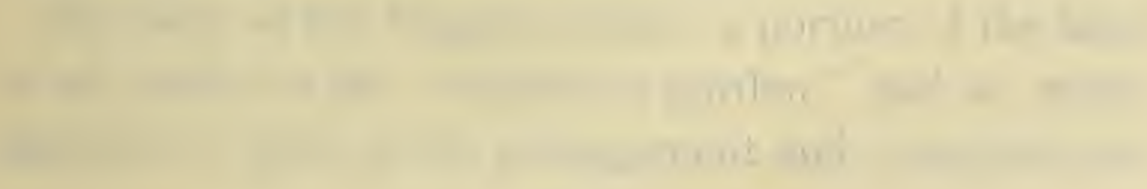


"HOW WELL A CHILD BECOMES THE GARDEN." 


\section{Chapter III}

\section{CHILDHOOD IN THE GARDEN}

$\mathbf{I}$

$F$ all children might be brought up in gardens, there would probably be few criminals raised, and many finally swept away. Practically every child loves gardens, adores digging in the ground, and comes very soon to taking an interest in the right way of planting and caring for growing things. Put a child into a garden, and with little instruction and no trouble you make him healthy, happy, and quite wise enough. How better can you educate his sense of beauty and order or cultivate in him a perception of natural laws? Give him his own special corner, his feeling of responsibility. The burden of flowers is a slight one to lay on young shoulders, and will broaden and straighten the alert young bodies, not bow them down. Answer all his questions too; it may necessitate a good deal of study on your part, but you won't be sorry for that.

On many of the English estates a portion of the land is set aside for the "children's garden," and as much attention is given to its arrangement and completeness 


\section{THE LURE OF THE GARDEN}

as to the rooms reserved in the house for the same young people. In this garden each child has a section for whose appearance and use he is responsible. There is usually a lawn for a playground, trees that can be climbed, and a pavilion or summer-house where lessons can be studied out-of-doors or games played on rainy days. Sometimes there is a stretch of smooth turf for bowls or croquet, or even a tennis ground, according as a greater or less amount of space is available. But, small or great, the place belongs to the children. They raise what they choose, fruits or flowers or vegetables, make their mistakes, and do all the work. They can have all the advice and guidance they want, but they are left free to make their own decisions and follow their own taste. Sometimes there are prizes for the prettiest bed, the choicest flower or finest vegetable, the contests being properly handicapped with regard to age and experience. The tiny plot belonging to the youngest toddler may present a rather bare and uneven appearance, to be sure. All the more do those belonging to the older ones witness, in color effects, neatness, and their well-cared-for state, how rapid is the advance made and how easily these outdoor lessons are learned. Some children undoubtedly develop more taste, more natural skill and feeling for garden work than others. But the child who does not take more than a perfunctory interest in the subject is almost always the child who has never been given the chance. 



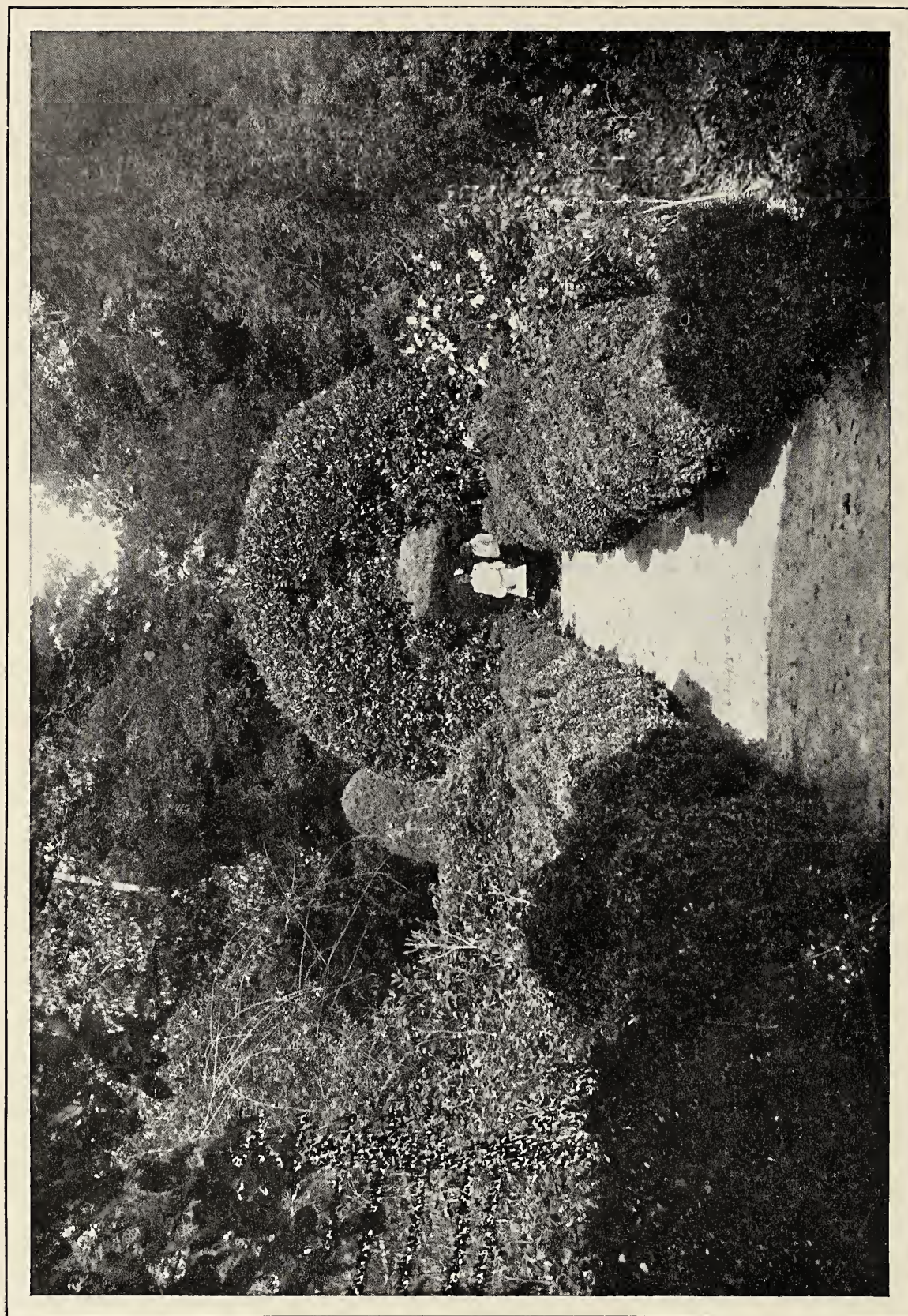

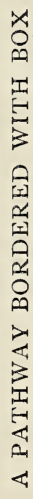




\section{CHILDHOOD IN THE GARDEN}

Unluckily, many people who have children do not own gardens, or at best spend but a short period of the year within reach of them, and there are many thousands of boys and girls who never know what it is to work in the ground. In an effort to overcome this sad condition, school gardens have been started in different municipalities, particularly the Middle West. Children who, driven from the streets to the tenement-houses and back again, had learned everything of which a child should be ignorant, and who had come to act in ways thoroughly appropriate to their hard and hideous surroundings, were taken to these gardens and set to work.

The result was and continues to be wonderful. Like Antæus renewing his strength at each contact with the earth, these children acquired a youth and joy they had never known, turned, in fact, into real children, digging up, as it were, out of the ground they worked, that innocence and happiness which should have been their birthright. Small lads of six and eight, already marked in the books of the law as "incorrigibles," toiled at the new labor, becoming almost what they ought to be at that age. Brown, lusty, red-cheeked under their broad straw hats, looking confidently up into your face as you came to see them at their planting, these " incorrigibles" strove with one another to produce the largest tomatoes, the fattest peas or beans, the most radiant nasturtiums or finest geraniums, pouring into 


\section{THE LURE OF THE GARDEN}

their work all the energy that, before a garden gate had opened to them, spent itself in mean and ugly deeds.

Even the child who is brought up with the utmost care and all the advantages, but who has never had this privilege of the garden, has lost a precious possession, has not been treated quite fairly, has been deprived of a host of lovely memories and much valuable experience.

Though your place be small, try to reserve a bit of it for the children; and where this cannot be managed, at least let the youngsters into your own garden. Let them live close to its flowers, even though a small foot treads over the borders now and then. Give them a pair of scissors and let them help cut the blossoms for the house, or snip off the dead ones; teach them to weed, to transplant, to train vines. You will be surprised to see how well a child becomes a garden, how much lovelier each is for the other. And it is they who, in the spring, will find the first snowdrop or crocus, or be found lying flat on their stomachs in the grass, solemnly staring at a violet. Teach them that a garden looks to them for consideration and care, and must be gently treated. It is a lesson a child learns easily, and if he does work any havoc, he will be in greater distress over the accident than you yourself.

Many a memoir or biography testifies to the strong impression produced upon the mind whose earliest years were spent in a garden, and though most of 



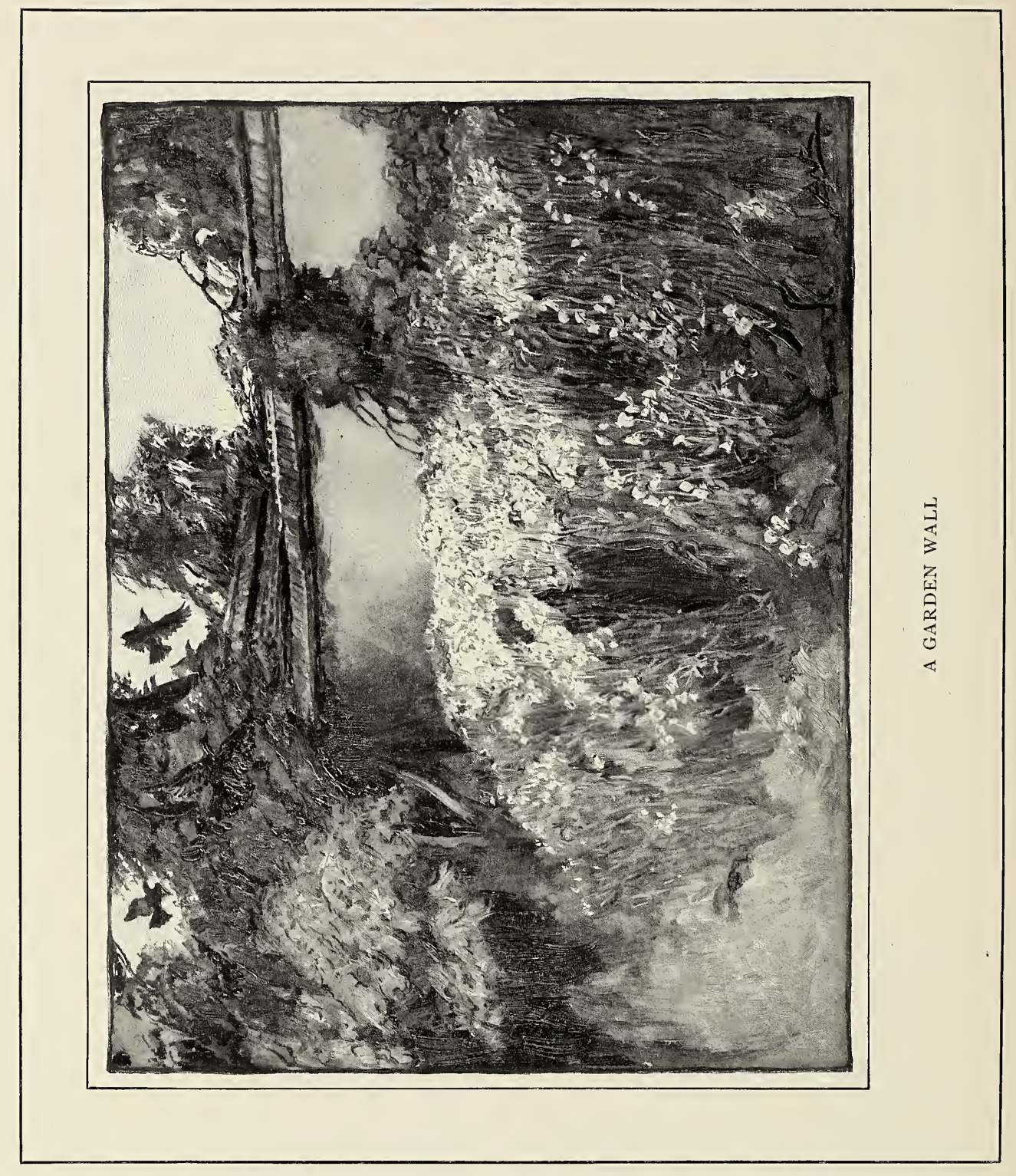




\section{CHILDHOOD IN THE GARDEN}

childhood may have faded into the indistinguishable background of the past, old people have no trouble in finding the old paths, in hearing again the murmur of the fountain and the voices of vanished playmates, or in remembering what flowers had first bloomed for them. And those among us thus fortunate in their youth who come back into a garden, find their memories stocked with all sorts of useful odds and ends of information regarding the best way to make this or the other thing grow, how deep seeds are to be planted, when to separate perennials or transplant annuals, with heaven only knows what beside; and this though years have intervened since we closed the gate of our childhood garden behind us, with never the time since to open another.

Gardens resemble reading in this, that where you have not acquired a taste for either in youth, you will never completely acquire it. And yet the atmosphere of flowers, as that of books, should be incorporated into the personality of every one, insuring as it does in a turbulent and hazardous world no small degree of happiness. Humanity has long joined in the acknowledgment that the love of reading is one of the great blessings of life, a rampart against ennui, an asylum from sorrow. Just as certain is the relief afforded by a garden. When you plant in a child's heart the love of its tended beauty, you are giving him an open sesame to the palace of peace, a refuge from 


\section{THE LURE OF THE GARDEN}

the dust and glare of the arena, something to which he can turn with joy when other interests die.

Many things happen in the soul of a child of which we have little conception, traveling as we do daily farther from the east. Dreams and fancies crowd upon them, and in seeking to adjust the world within to that without, important transmutations occur. It is as well that these adjustments should not be too violent, nor the contrast between dream and reality too marked in the beginning.

If your child spends hours musing down there where the fountain drips musically into the little pond overfull of white and red lilies, you may feel sure that he is building part of a foundation of life not unworthy. Send him and his brothers and sisters out to play under the pink wonder of the azaleas, or to chase the flying leaves over the lawn when October gives the signal for the fire dance, and something beside the rewards of exercise and fresh air will be given them. Teach them their lessons in the rose-grown summer-house, and if their attention wanders, following the tip-tilted flight of a butterfly or harkening to the excited warbling of a wren, do not bother overmuch. The best things are not taught in words, and what man has done is not the only truth to be learned.

And as for health! Just look at them, kept out from earliest morning to sunset, reeking of mother earth like a root fresh plucked from the soil, lusty of limb and 
"LET THEM LIVE CLOSE TO ITS FLOWERS." 


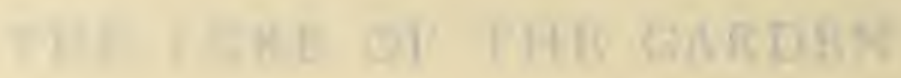

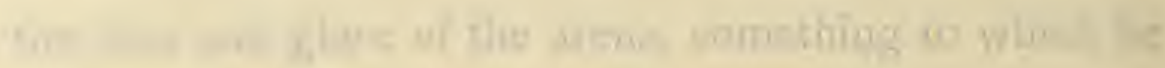

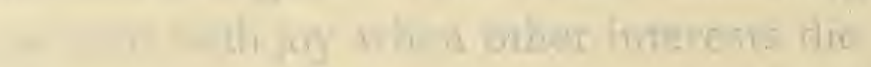

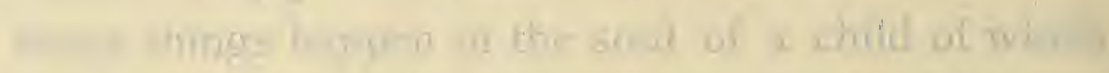

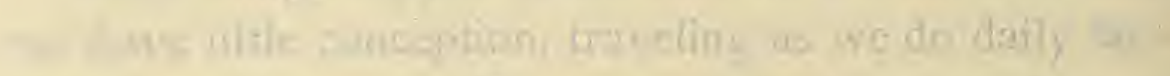

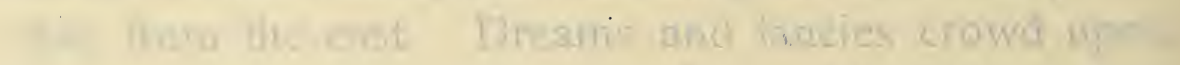

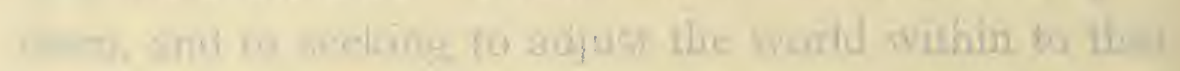

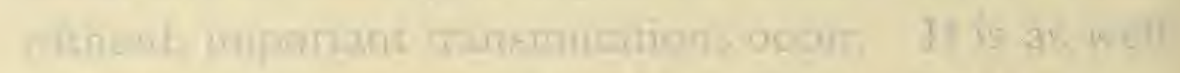

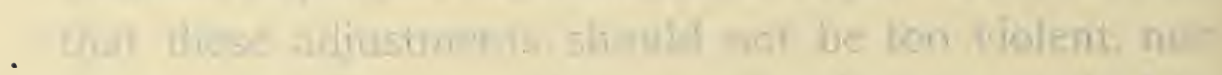

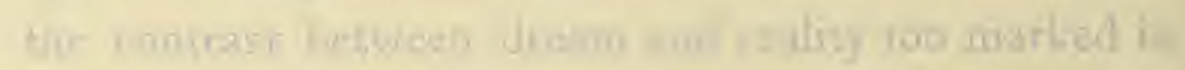

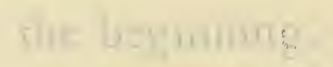

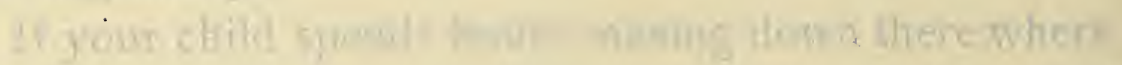

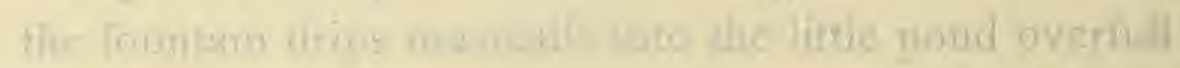

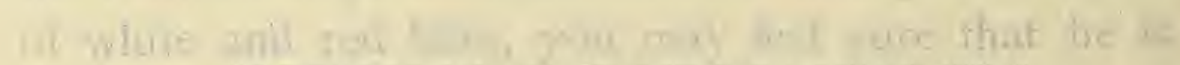

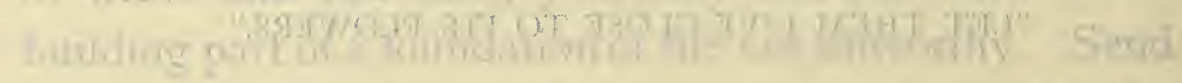

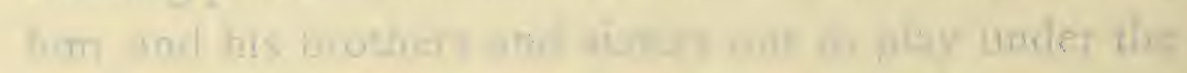

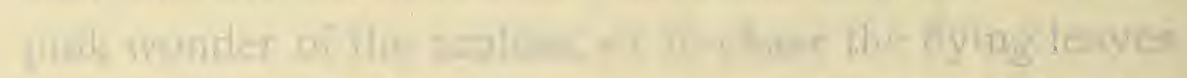

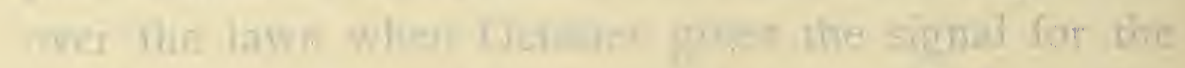

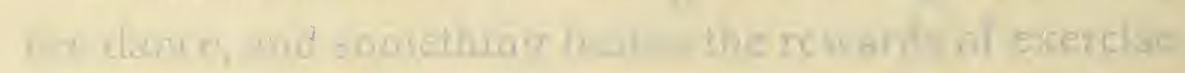

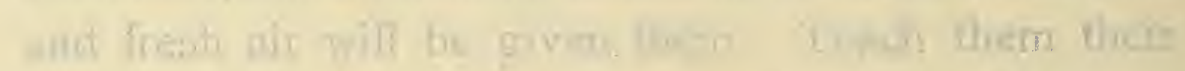

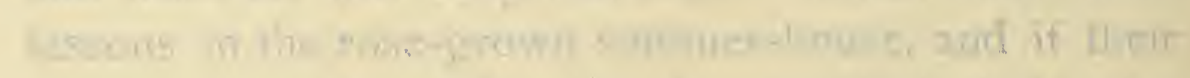

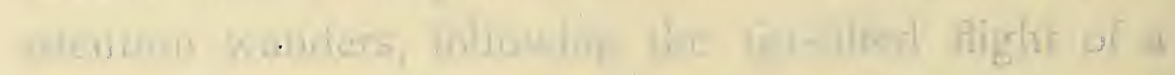

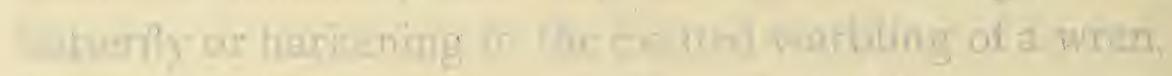

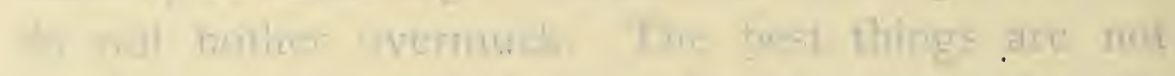

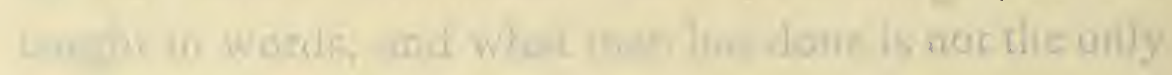
$x+\log$ lisirned

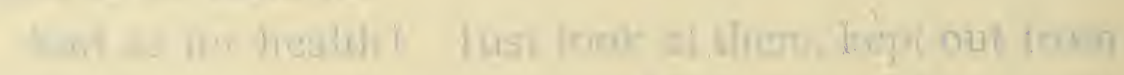

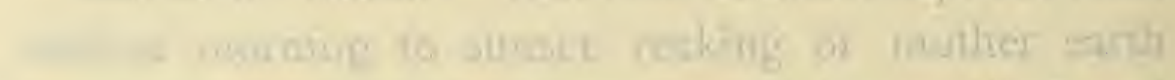

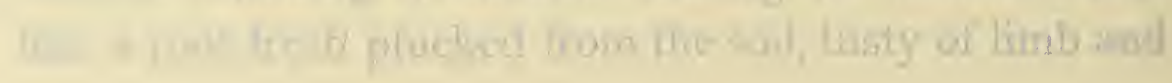




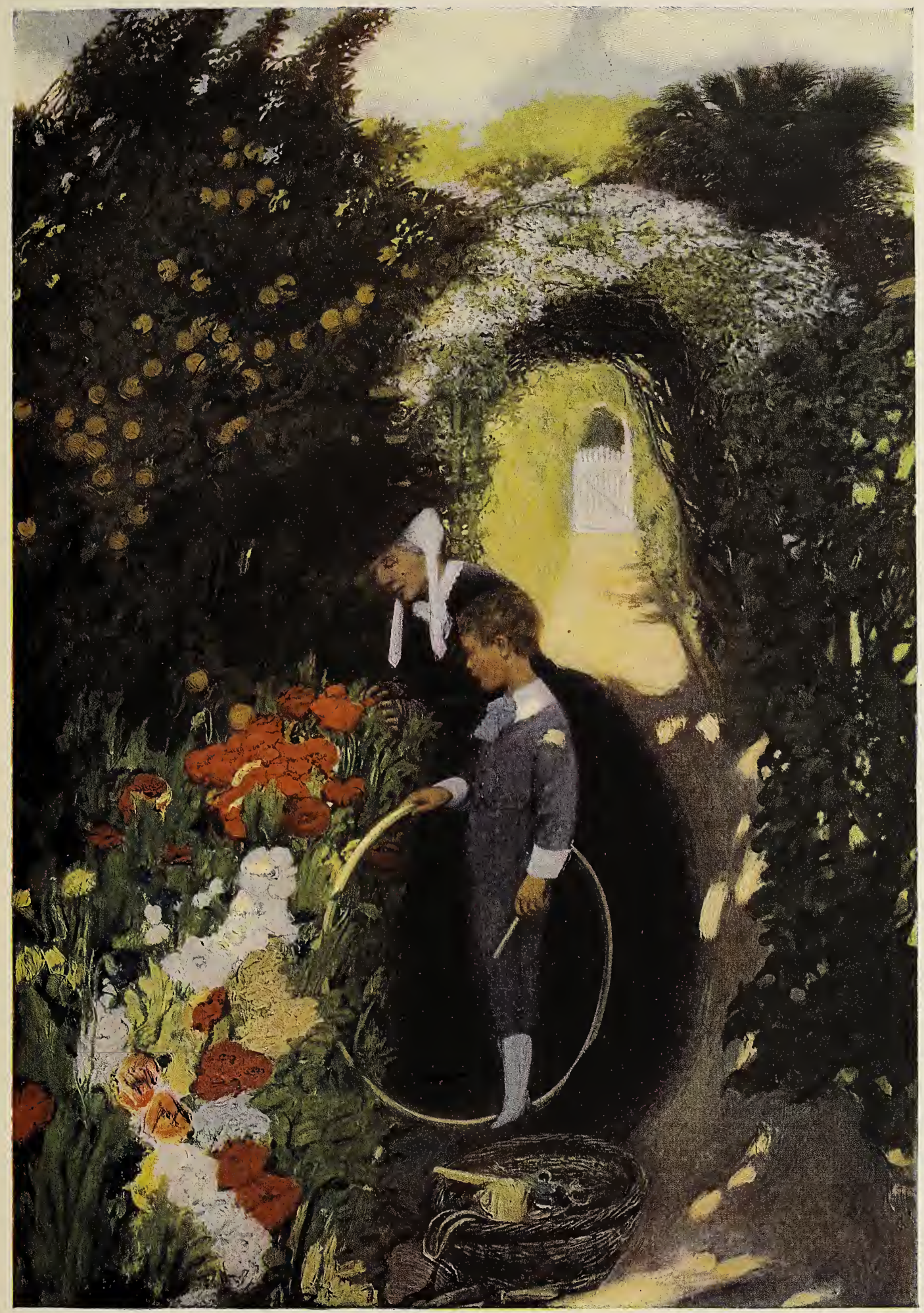





\section{CHILDHOOD IN THE GARDEN}

rosy of cheek, with eyes as clear as a woodland pool. Wise in nature's ways, serene and merry, no nervous, prematurely school-aged children, these. Possibly they are a bit behind in the usual smattering of class-room courses, but they are likely to have more than a passing acquaintance with the actual habits of the grand old mother, her birds and insects and plants, her lovely appeals and eternal interests.

Make your earliest school-room the garden and you are not likely to regret it. You won't have to worry over your boy or girl's anemia, or be troubled with nerves out of kilter, or with the results of overstudy and under-development. And if any child in the world needs a garden to grow up in, it is the American child, with its alert, sensitive mind, its too-tense ambition and love of competition, its unconscious assimilation of the spirit of hurry that so bedevils its elders. Out with them, then! Let the walls be high enough to give them seclusion, let them have undisturbed long hours alone there, let them come to feel and comprehend the sure, slow methods of nature, its honesty and beauty. Let them have a place where they can romp and shout and tumble, and let them learn also how much patience and devotion is required to bring even a flower to perfection.

My own earliest recollection is of an English garden where the fragrance of wall-flowers lay sweet from June to November, and where we were occasionally kept 


\section{THE LURE OF THE GARDEN}

awake by the nightingales, singing through the long summer twilights. At the foot of the garden farthest from the house, the wall faced south, and was quite covered behind plum- and apricot-trees neatly spread and tacked down with pieces of felt. Many a happy morning and smashed finger testified to the earnest labor of our small hands, permitted to assist in subduing the natural inclination of those trees to stand on their own roots and maintain an independent existence. Next to the trees were rows of currant- and gooseberry-bushes, and there was a cucumber frame and a number of long narrow beds of lettuces, radishes, peas, and vegetable marrows, as well as two huge bushes of lavender, whose tiny fragrant blossoms we helped to gather.

In front of the house was the flower garden, separated into two unequal parts by a gravel pathway that led from gate to door. Along this path went prim standard rose-trees presenting their bloom in the form of a bouquet, and standing very erect. A tall arbor-vitæ hedge shielded the garden from the road that led to the village, and I never smell its pungent odor to this day without a drifting memory of that English garden.

There was a little greenhouse, and in a corner of the lawn a table and comfortable seats where tea was served in fine weather. Many flowers grew in the long beds that ran all round this lawn, close to the walls, which were buried in ivy, and close to the house were rows of hollyhocks and larkspur in splendid clumps. In my 


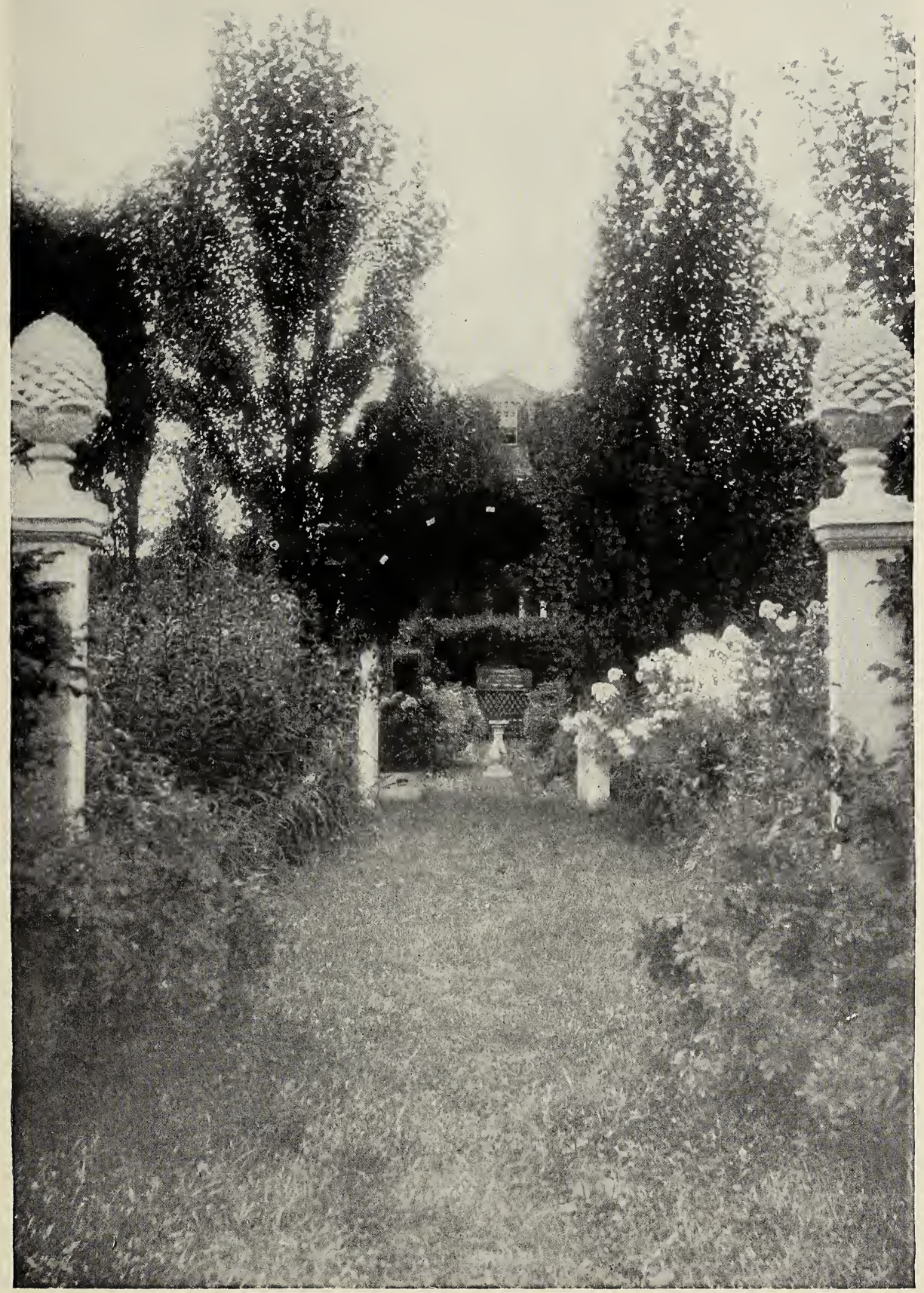

A PLACE TO DREAM AND LINGER IN 



\section{CHILDHOOD IN THE GARDEN}

memory it is always summer in this garden; I have not the least recollection of it save in the heyday of its bloom.

Marvelous were the games we played there, and unforgetable the happiness we enjoyed. We each had our small set of tools, our square of earth. We sometimes brought wild flowers from hedge-row and meadow to adorn these beds, and assiduously, though without result, planted boughs of trees. In one instance, however, a willow took hardy hold and proceeded to grow amazingly, arousing in us all the greatest excitement. It was, in fact, one of the big moments of life, an immense vindication of faith.

I suppose it is because of this garden, that remains so secure and beloved in my mind, that the spectacle of children growing up in city streets and schoolyards, or even in those unsatisfactory expanses that do duty for gardens in many suburbs, fills me with desperate pity. It is so bitterly unjust, and in many cases so unnecessary. For gardens could often be made, at some sacrifice perhaps, yet little enough where the reward is considered, in many a place where they are not permitted. To rob yourself of a garden is bad enough; but to take from your child his inherent right to one, a right to which that ancient story of the garden of Eden perhaps alludes, is almost like depriving him of the use of a hand or an eye. 

THE SOCIAL SIDE OF GARDENS 


\section{A CHAPLET OF GARDEN FLOWERS}

BY MICHAEL DRAYTON

Here Damask Roses, white and red, Out of my lap first take I, Which still shall runne along the thred, My chiefest Flower this make I; Among these Roses, in a row, Next place I Pinks in plenty, These double Daysyes then for show, And will not this be dainty? The pretty Pansy then I'll tye Like Stones some chaine inchasing, And next to them their neere Alye, The purple Violet placing.

The curious, choyce, Clove July-flower, Whose kinds hight the Carnation, For sweetnesse of most soveraine power, Shall help my Wreathe to fashion; Whose sundry cullers of one kinde First from one Root derived; Then in their several sutes I 'll binde, My Garland so contrived. 


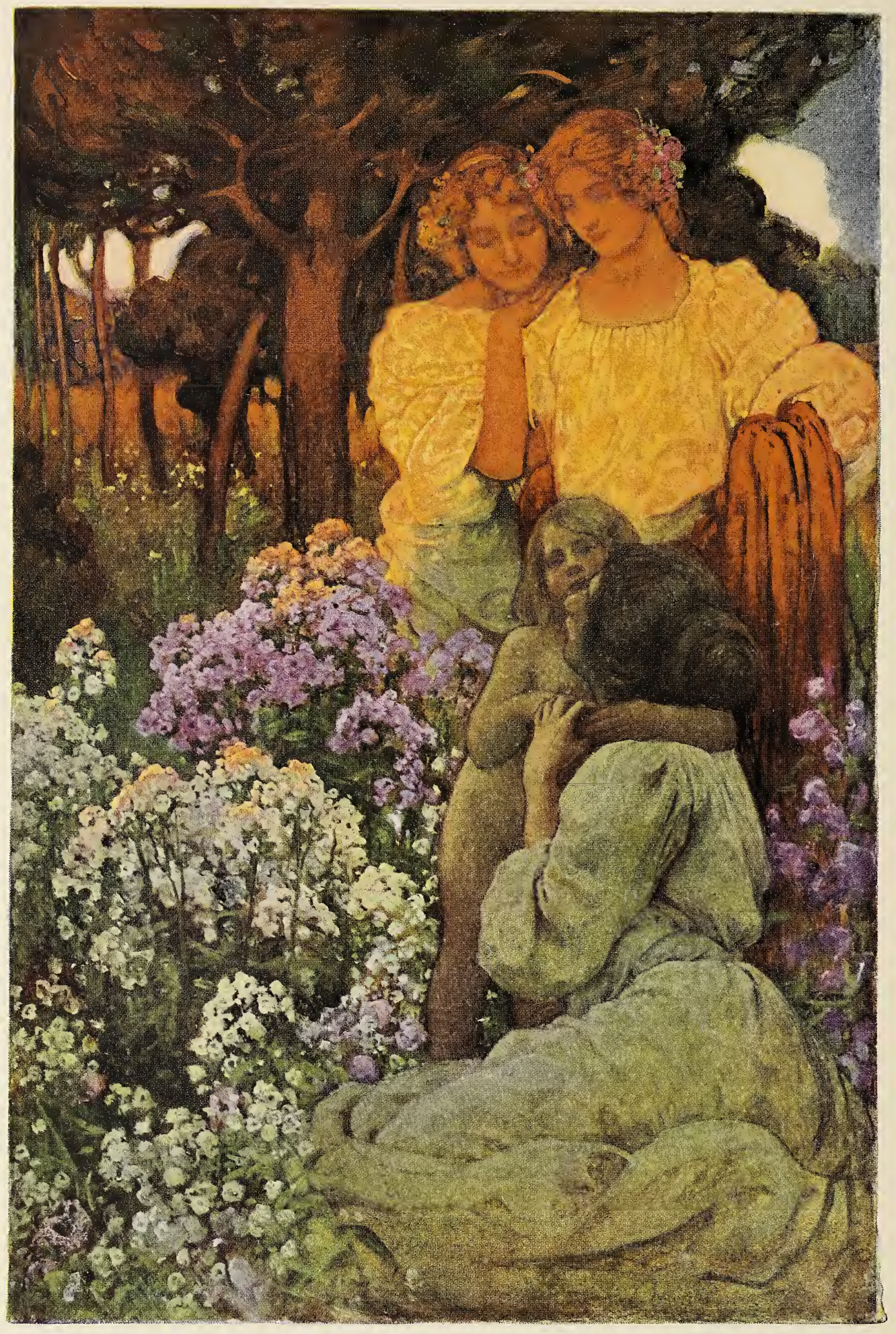






\section{THE SOCIAL SIDE OF GARDENS}

$7 \mathrm{HE}$ art of using a garden is hardly to be acquired in a moment; it is far more difficult 1 than learning how to make one! But it is well worth the studying, for a properly used garden is capable of yielding an infinite amount of pleasure. Let the social charm of the garden once come to be felt and it grows to be indispensable; the possessor of so much as an acre of ground will not rest until he has his own, with its individual excellencies and possible makeshifts, but at least entirely his.

For though privacy is essential to a garden, it does not take great space to secure this primal necessity. It is by no means the few large places that count: it is the many little ones; the small places transformed into a sweet and intimate personal possession to be shared with one's friends, where the flower of social intercourse may be cherished quite as carefully as its fragrant sisterhood of the beds and borders. Discrimination is an important attribute of character that develops slowly, both in individuals and communities. In America it has not 


\section{THE LURE OF THE GARDEN}

yet been sufficiently considered, a fact as clearly proved by the usual suburban garden as by anything else. For an expanse of ground planted with flowering shrubs and merging unmarked into the adjoining plot, to continue indefinitely from house to house, may be charming to look upon but a garden it is not; any more than the marble arcade of a down-town skyscraper open to the general public is a home.

The real garden must be protected from the passer-by; must have hedge or wall, must exclude what does not "belong," or cease to exist. It must be a place beyond whose confines the weary world may go hang. It must spell intimacy, and its full secret be known only to the chosen; be a privilege shared, rather than a possession displayed. The garden is not the place for a "crush," for a fashionable reception, for a function, but for actual happiness, real hospitality, and affectionate comradeship; that social intercourse, in fact, which yields enjoyment, not weariness.

In any histoire intime of the days when the agreeable assemblage of mutually pleasing persons was a fine art, the garden plays its part. Infinite care and art were expended to make these outdoor rooms enchanting, and in arranging them so as to create a mingled sense of possible solitude with the constant potentiality of charming companionship. A history of social life is to a large extent a history of gardens, reflecting as they do to a remarkable degree the characteristics of the society that 


\section{THE SOCIAL SIDE OF GARDENS}

made and enjoyed them. Even as a scientist reconstructs his monster from a portion of bone, so might the student of human manners rebuild an entire social régime from some ruined garden whose tangled boskets and moldering statues whispered their secrets of the past. The pictures of Fragonard with their veils of misty leaves and gracious rose-twined marbles tell more of the actual social atmosphere pervading the reigns of the Louis than a volume of printed pages could convey. And to wander through one of the gardens built during the Italian Renaissance is to have the soul of a whole generation explained.

The society of the Italian principalities in the sixteenth century was as brilliant as the art, with all its revival of learning, poetry, painting, and architecture. Nor were the women less ardent, less cultured than the men. The passion for creation, the creation of beauty, which obsessed every one, flamed in them too. A few wrote or painted; but most found the fulfilment of their desire in fashioning a perfect frame for the labor of the greatest. So it was that many of these gifted women turned their talents to the making of gardens, gardens peculiarly suited for social enjoyment, for gatherings of the wise and the witty, gardens expressing a certain high reserve and yet inviting a pleasant freedom.

"There was a passion for beautiful gardens in the Italy of that day," says Christopher Hare, in her memoir of Baldassare Castiglione, author of the world-famous 


\section{THE LURE OF THE GARDEN}

"Book of the Courtier." And, going on to describe the particular garden where the young nobleman spent his childhood, she writes: "Closed in by thick dark hedges of box and yew, sheltered by plane-trees to the south, so that there was always shade at noon, the gardens were laid out in terraces in front of the castello, from whence stretched out long straight walks covered with vine-grown pergolas and bordered with rose-trees and jessamine. Green lawns sloped down to the steep banks of the river Oglio, with a marble fountain in the center of the turf, and orange-trees in boxes at every corner, while in distant nooks were sylvan arbors and strange grottoes with quaint figures of animals carved in stone. A place to dream and linger in of a summer evening, green with perpetual verdure, musical with the voice of waters, glowing with luscious fruits and the sweetest flowers."

It was in places like this that the duchessas and marquesas held their choicest parties. What a picture must have been presented when, in the latter part of the golden afternoons, the company began to gather on the shaded terraces, the men in doublets of velvet and satin and silken hose, with massive gold chains round their necks and wearing splendid jewels as clasps for the feathers in their caps, or set into their sword-hilts, the women shining in priceless fabrics, with veils of gold tissue and strings of gems. Wine was served in crystal cups, and cakes and sweetmeats on golden plates, and 


\section{THE SOCIAL SIDE OF GARDENS}

" there were sweet discourses upon stringed instruments, with songs whose words and music had often been composed by one of the company." For in these chosen assemblies one found not only the high nobility of birth, but also the lofty companionship of men of genius and talent; often the two met in the same man, as with Baldassare himself.

Strange masques and lovely eclogues were presented before the guests, the actors being drawn from their ranks and, since the little plays were written by one or more among them, personal allusions, veiled sarcasms, and delicate flatteries which would have been lost to the world at large, aroused in the chosen audience "much approval and the most joyous laughter." There were dances too, and mock battles fought to a measured time, with stately steps and clash of blades. Great stone seats over which rugs were thrown were arranged for the ease of the company, and often the moon rose to find the lingering guests, loath to leave, listening to the verses recited by some fair girl with the gift of improvising, or vying with each other in the criticism of a recent work of art or literature.

Even so long ago as the thirteenth century, three hundred years before the white light of the Renaissance was to break over the world, the love of gardens awoke with the dawning perception of what we mean nowadays by social intercourse between the sexes, and the art of conversation went forth into the green world of grow- 


\section{THE LURE OF THE GARDEN}

ing things hand in hand with the new birth of lyric song. The Minnesinger, wandering over Germany, sang not only of his lady, but, looking about him and discovering the lily and the rose, the freshness of spring and the bird in the tree, he found nature to be beautiful and celebrated it in as lovely strophes as have ever been sung. It was long before the time of formal gardens; but the happy knights and their ladies went out into the green meadows and flowering woods, holding court:

Where played a flowing fountain

With fresh clear life inherent

And as the sun transparent . . .

Their ample court and their wide hall

Were the linden green and tall,

The sunshine and the shadow,

The spring and the meadow,

Grass, flowers, leaves, and blossom. . . .

These lines by Gottfried von Strassburgh date back to the first few years of this great century. It was a time that saw the beginning of much we now term modern; and the perception of the social value of nature assisted by art was one of its most charming discoveries.

In the England of the sixteenth century the gardens as well as the society were less formal, simpler, rougher than the Italian, depending more on nature than on art for their appeal. We have a fine picture of an English festival occurring in the gardens and park of Kenilworth during a visit of Queen Elizabeth to Lord Leicester. As the maiden queen and her escort entered the con- 


\section{THE SOCIAL SIDE OF GARDENS}

fines of the earl's grounds, the cavalcade was met by a train of sylvan spirits at whose head danced a shepherd, singing a madrigal that vaunted Elizabeth under the title of Diana, while the nymphs and dryads scattered fresh flowers in her path. As the procession moved on, fairy flutes blew from the woods on either side the path, and finally Pan appeared with attendants in fantastic costumes to represent animals and mythological creatures, and offered to the royal guest the freedom of his green domain. Later, amid the roses and mazes of the garden an al fresco meal was served by beautiful boys dressed as Greeks and wearing garlands. Whereupon, it is related, a mischievous and fantastic spirit took possession of queen and courtiers and ladies-inwaiting. Elizabeth, "who loved a romp," gave free rein to her fancy. There was a dance on the lawn that savored of village merry-making, and not a grotto nor a bower but hid a pair of lovers.

In France during the period spanned by the reigns of Louis XIV, Louis XV, and Louis XVI the garden as a background for court life touched its apogee. Exquisite fêtes were given toward whose perfection the king himself, as well as the foremost artists of the court were eager to contribute. Designed on a magnificent scale, the gardens in and near Paris, as well as others surrounding the country châteaux of the haute noblesse, lent themselves to the stately ceremony and almost incredible luxury of the times. Even the so-called simplicity of 


\section{THE LURE OF THE GARDEN}

the summer days of Marie Antoinette at the little Trianon was a silk and satin simplicity, with diamonds for dewdrops. The gardens were as artificial as the manners, and tree and flower almost as far removed from their purely natural condition as were the lords and ladies from the naked freedom of Adam and Eve.

There is a story somewhere in St. Simon's Memoirs concerning a duchess who hated the confinement of a room, and who always led her lover forth into the garden, wandering with him along winding paths where the larkspurs, hedges, and rose-trees grew so tall as to hide from view whoever passed between them. Behind the dreaming pair, at a discreet distance, followed a servant with a rake, whose duty it was to carefully obliterate the footprints of the lovers, and to leave the path as smooth and fair as though no human feet had ever touched it. This garden of the vanished steps was a place covering several acres, and sloping down from the château in a series of terraces, with marble fountains in the center of each throwing fantastic jets of water high into the air, and surrounded by rows of formal trees and beds of flowers as brilliant as jewels. Another lady is said to have dearly loved the moonlight, and to have given several exquisite entertainments in her gardens by its soft illumination. On one such occasion all the guests were asked to come in white raiment. The costumes were of white satin, cloth of silver, and embroidered silks, while the only 



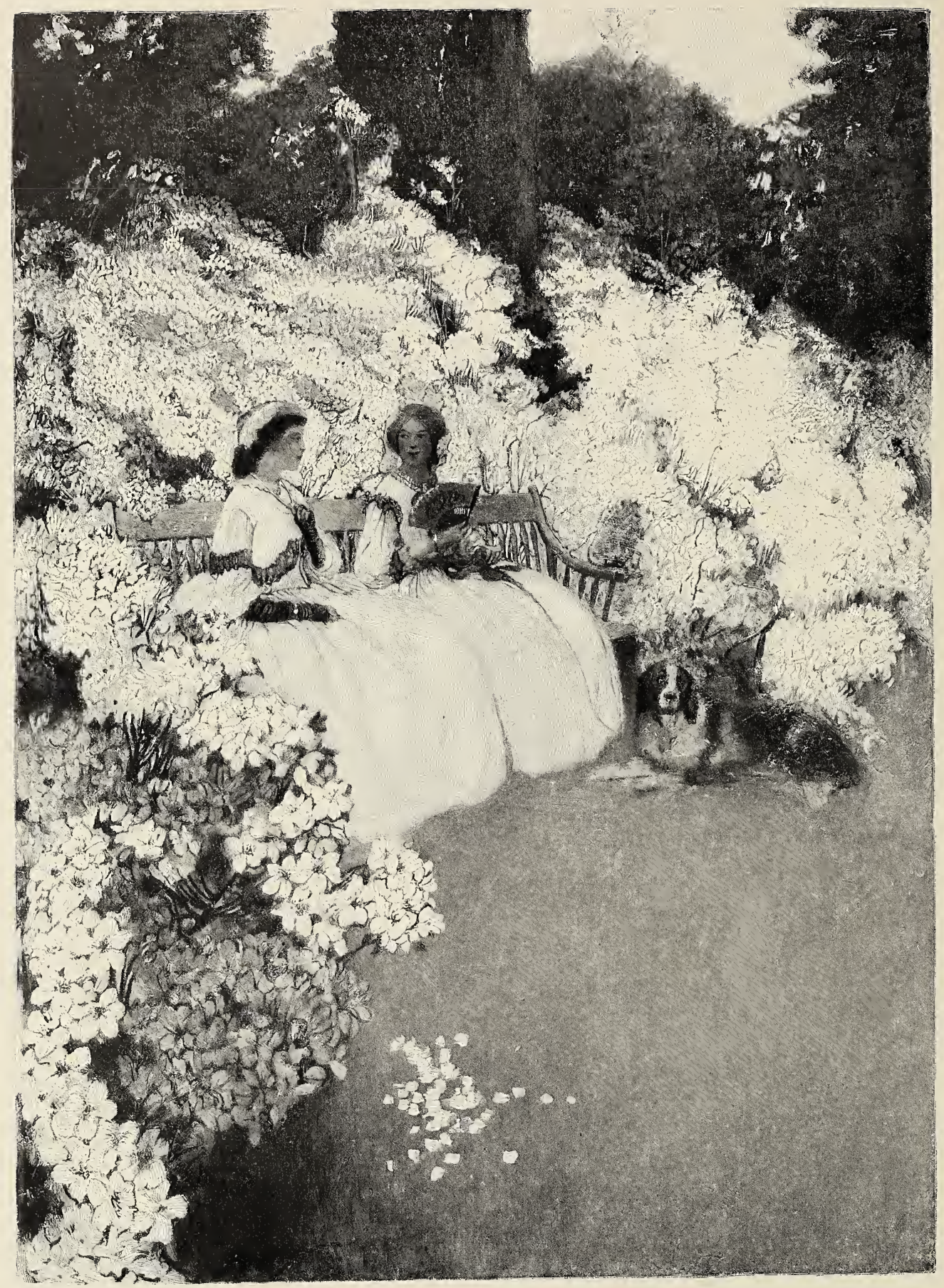

A VISIT ON THE LAWN IN THE OLDEN TIME 


\section{THE SOCIAL SIDE OF GARDENS}

ornaments worn were of pearl and diamond. Silver lamps were set upon the stone balustrades, and the night culminated in a dance representing Apollo and the nine Muses given on one of the terraces before a dark background of box and ilex.

The love of the out-of-doors as a place for social enjoyment was by no means confined to the rich or to the aristocracy. Hardly a village but had its treegrown common, where young and old met for the day's relaxation after working hours, the old to gossip, the young for trials of strength and dancing. May-day in an English village of the "spacious times" must have been a scene worth remembering. The May-pole, reared in the center of the green, was crowned with a garland of spring flowers and wreathed in greenery. From it radiated the long flower-trimmed ribbons to be held by the fairest maids of the country round as they went through the intricate paces of their dance, keeping time to ballads sung by the merry circle of young men in their best holiday dress, who, at a given moment, joined in the dance and swept their sweethearts away with garlands flung about their necks amid the laughter and rough jesting of the jolly crowd.

Following this came the wrestling matches, the single stick bouts, the foot-races, and jumping matches. Prizes of casks of ale, butts full of malmsey, fat pigs, silver pieces and horses bridled with silver bits were offered, and the interest in these events was so intense that the defeat of 


\section{THE LURE OF THE GARDEN}

a favorite was often the signal for a free fight. Then, as evening drew on, long tables were spread under the trees, loaded down with huge pasties and bowls of sack, great quartern loaves and roast suckling pigs.

The eighteenth century in England was not only the time of the drawing-room reunions of wits, blue-stockings, and literary folk of various degrees, but also of a somewhat ostentatious return to nature; a time when poet or playwright planted his own garden and walked therein or bid his friends to tea there, with a careful eye of honest approval upon the excellent sylvan figure he cut on his trim lawn among formal parterres and neat hedges. Nevertheless, these little parties must have been singularly pleasing. Pope's place at Twickenham witnessed gatherings of his friends, chosen from those with whom he was not at the moment quarreling, gatherings that for brilliancy of talk and variety of interest can hardly be matched in tea-table history. Hither came Gay, Swift, Lord Bolingbroke, Steele, Richardson, Walpole, with many another famous wit. The garden with its view of the Thames was charmingly secluded, with an arbor of rose and honeysuckle where Pope's mother kept her tea-table. "God forbid you should be as destitute of the social comforts of life, as I must when I lose my mother," Pope once wrote to Swift. A pretty picture it must have been, the old lady under the vinecovered trellises, bending over the handleless cups and huge teapot, the buttered scones and cakes, offering her 


\section{THE SOCIAL SIDE OF GARDENS}

son's hospitality to that brilliant group to whom conversation was an absolute necessity, and who perfected their phrases with all the fervor of an artist's devotion to his art. There sat Walpole, his bitter wit etching the absent for the laughter of the present; Gay, the dreamer, somehow slipped into the most comfortable chair; Swift, who has been commending Pope upon the subterranean passage from the house into the garden, berating Gay for laziness, Bolingbroke for levity, and man in general for existing. The long shadows stretch across the lawns that rise gently to the house, and every inch of the garden shows its master's personal care. Pope loved this place with real passion, spending much money and more time upon it; indeed, several of his friends in their letters bewail his becoming " a true country gentleman, and seen no more in town."

To-day, the use of the garden is far more generally understood abroad than here in America. England is perhaps preëminent in this direction, and it is beyond dispute that there is a charm and simplicity to countryhouse entertaining there which is attained nowhere else. Its careful carelessness is among the most delightful of modern achievements, the tact with which personal freedom is mingled with the social duty of hostess and guest touching upon perfection. It is the garden, rather than the house, that gives the key-note. The most charming part of the day is the tea hour on the terrace, or near the tennis-courts, when every 


\section{THE LURE OF THE GARDEN}

one is grouped about on rugs and in wicker chairs, or playing at bowls or croquet. When the neighborhood friends drop in on horseback, or in pony-chaise, hailing each other cheerily, coming and going with the utmost informality, lending a hand in the games, crowding to the tea-table. An M.P. just up from London, hastily changed to the flannels consecrated to the country, with a cup of tea in one hand and a racket in the other, stops to talk eagerly - not of politics, but of the new rose-bed he has set out, or a breed of dogs he is improving. Near by a group of women are discussing the suffragette situation with a couple of literary men, or a party on the river is being planned. The groups mingle, dissolve, form new combinations, wander away in pairs, or depart singly on various errands bent. An ease, an informality impossible within the walls of a house obtains in these gardens, gardens valued as highly as the old family portraits, dating back very often as far as the family history itself, and perfectly suited to the requirements of the people who love and live in them.

This feeling for the garden as a social factor undoubtedly exists in America, but in England it is general; hardly a cottage but has its little bit of flower and vine, its wall overgrown with ivy and sweet with wall-flowers, where the family may sit toward evening as undisturbed by outside intrusion as the people at the manor-house. In France and Italy, too, the poorer portion of the population have this love of gardens. Whenever possible 


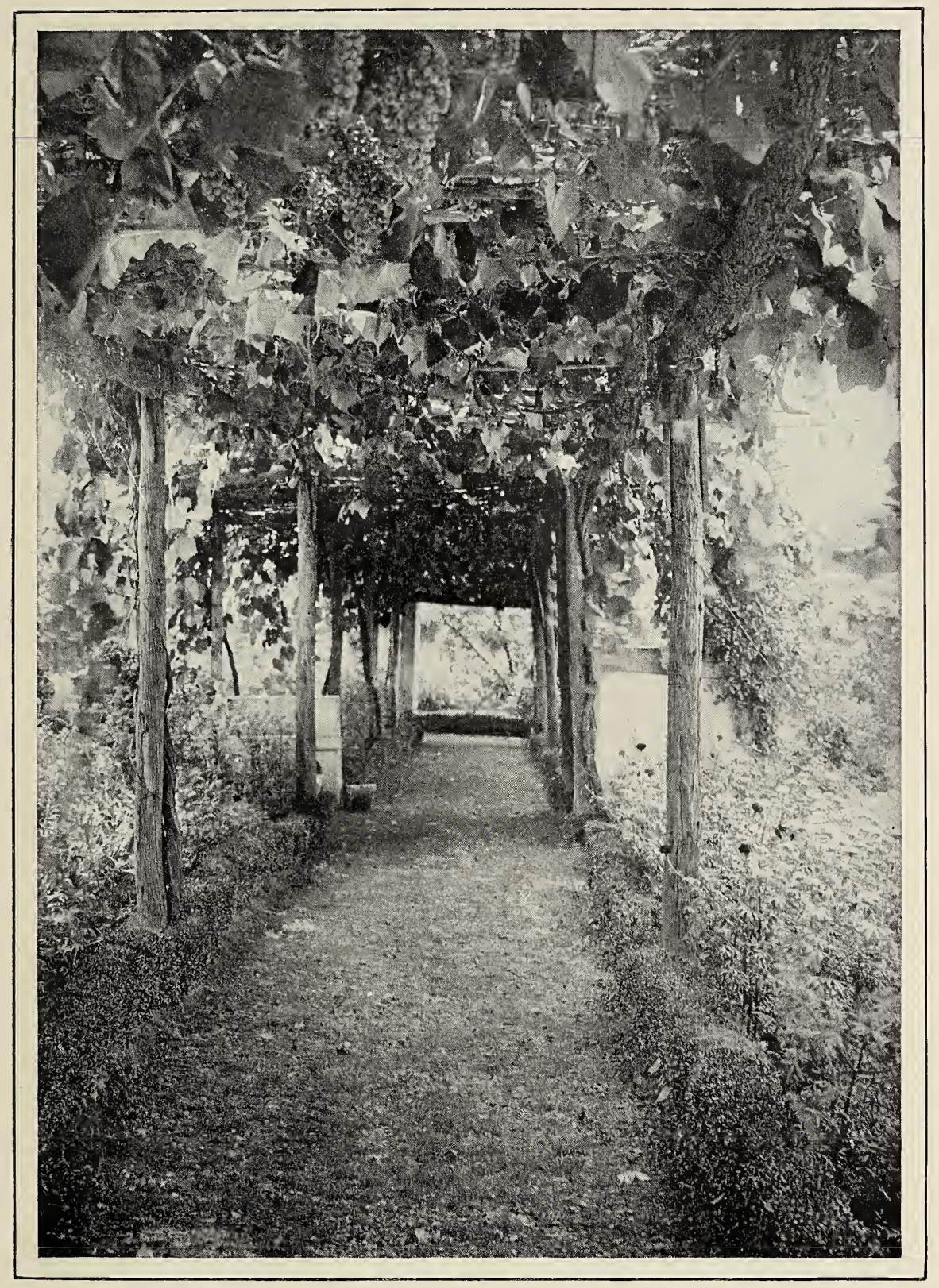

THROUGH GREEN ARBORS 



\section{THE SOCIAL SIDE OF GARDENS}

they live and eat in them, training vines to keep out the alien eye quite as much as for a protection against the sun.

There are, however, many exquisite gardens scattered all over the United States, in New England, in the South, in the West; gardens whose owners have discovered the precious uses to which they may be put and whose recollection is sweet to the guests privileged to enter them. I recall a summer afternoon in a Maine garden overlooking the shining reaches of a river. The great Colonial house merged through green arbors into the beds gay with corn-flowers and canterbury-bells, sweet with heliotrope and lily, separated each from each by grassy paths edged with box, and given seclusion by rose-hung wall and pergola. The small group sat idly enough among the fragrant smells and gentle sounds, flutterings of leaf and bird, trickle of fountain, sigh of pines. Tea was over, and the west was smoldering with intenser color. The half-dozen guests were all busy persons - an actress who is world-renowned, a playwright, an editor, a newspaper woman, a couple of artists. The desultory talk flowed from one to another, interspersed by utterly contented silences. The topics centered upon what and when to plant "things," the massing of colors in beds, the joy of a sun-dial, the vagaries of certain bulbs or slips; not one but hoped some day for a garden of his own. And altogether delightful as were the days and the amusements of that hospitable 


\section{THE LURE OF THE GARDEN}

week, it is the garden hour that lingers in the memory unforgetably, with its indefinable charm, its release of the spirit, its ease and irresponsibility. The garden was enough; no one need exert mind or body to provide entertainment or dispel ennui; with the result that everybody, throwing the social burden upon complaisant nature, became exquisitely his actual self, meeting his neighbor on a different, a more intimate basis than could have been possible elsewhere.

Such gardens and such hours are multiplying with us, and are a valuable indication of our increasing sanity of life, our developing taste and realization of what it is that is truly worth while, and that leisure and peace and seclusion are assets for which we should be willing to make some sacrifices. 
GARDENS AND GOSSIPS 


\section{IN MEMORY'S GARDEN}

BY THOMAS WALSH

There is a garden in the twilight lands

Of Memory, where troops of butterflies

Flutter adown the cypress paths, and bands

Of flowers mysterious droop their drowsy eyes.

There through the silken hush come footfalls faint

And hurried through the vague parterres; and sighs,

Whispering of rapture or of sweet content,

Like ceaseless parle of bees and butterflies.

And by one lonely pathway steal I soon

To find the flowerings of the old delight

Our hearts together knew-when lo, the moon

Turns all the cypress alleys into white. 



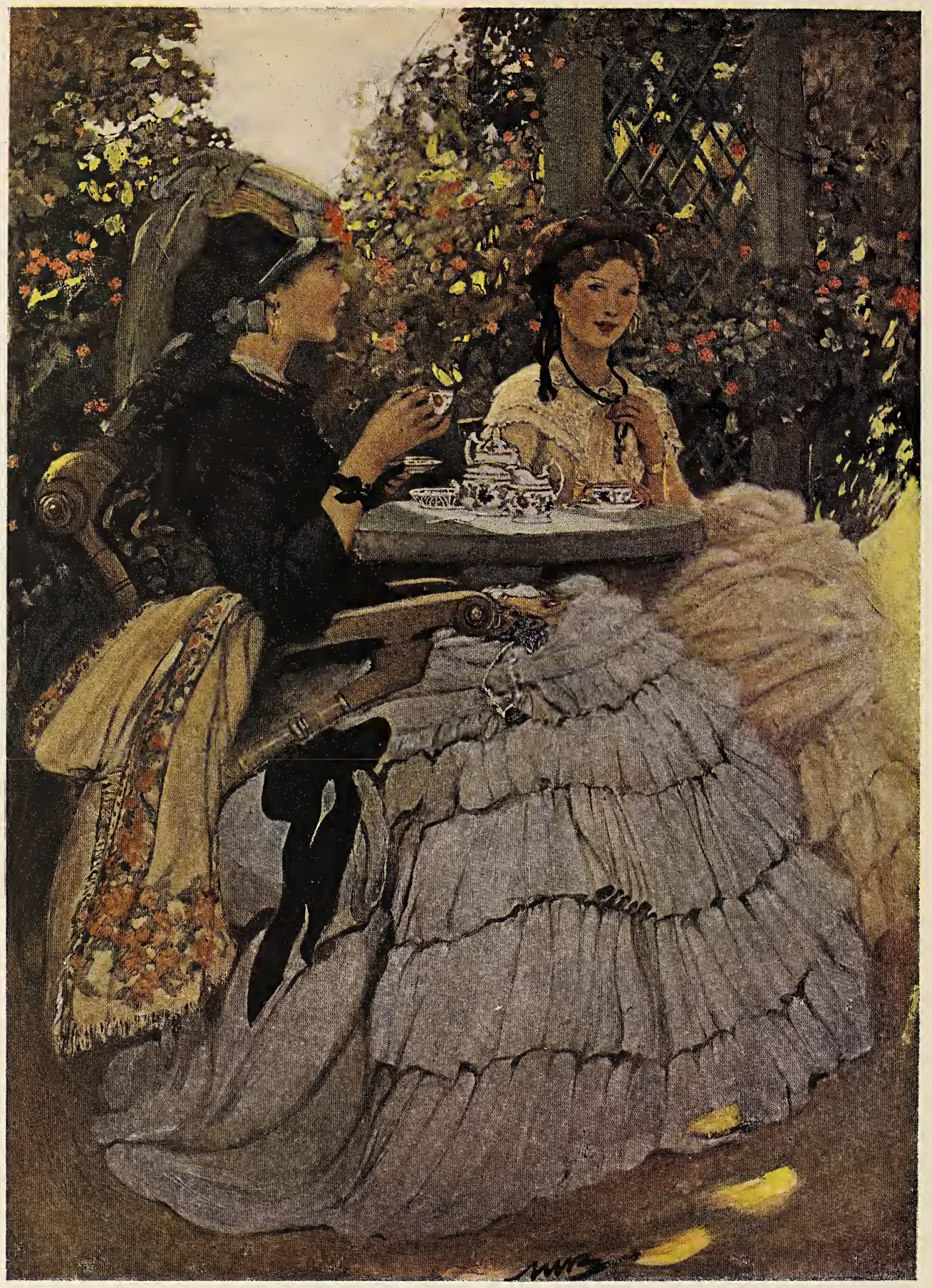




\section{Chin in in

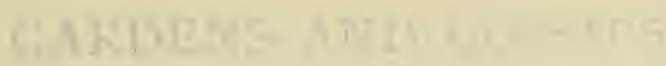

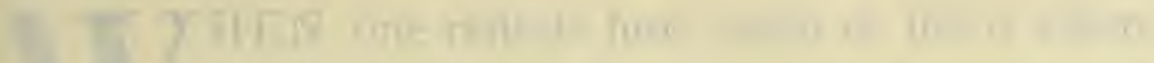

$$
\begin{aligned}
& 15 \text { in } 1 \text { : }
\end{aligned}
$$

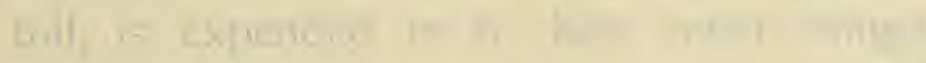

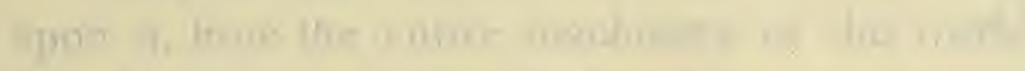

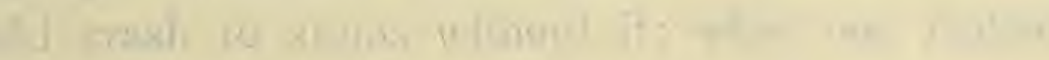

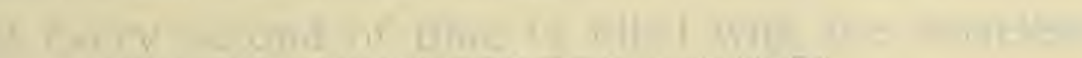

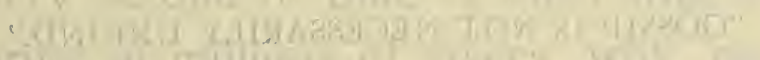

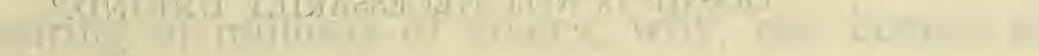

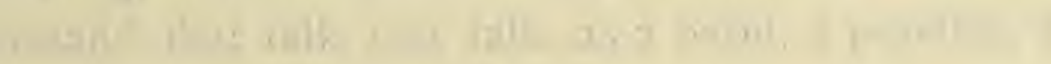

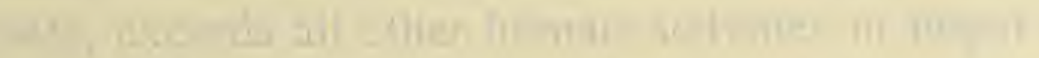

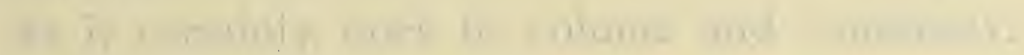

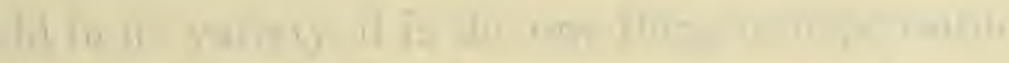

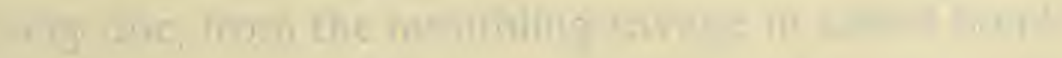

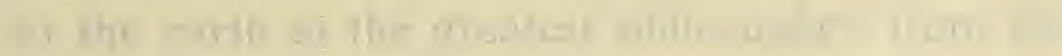

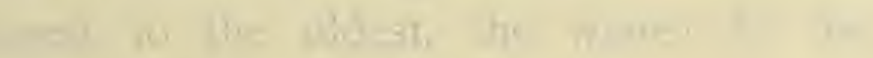

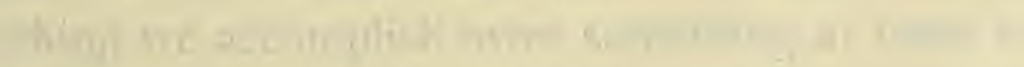

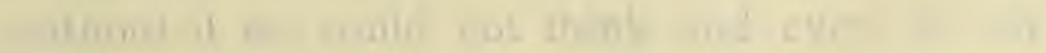

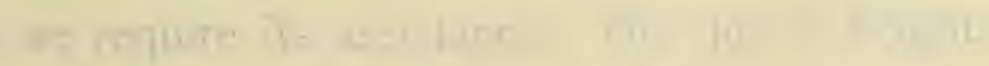

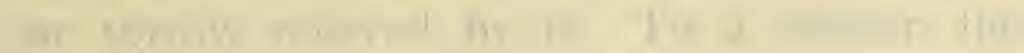

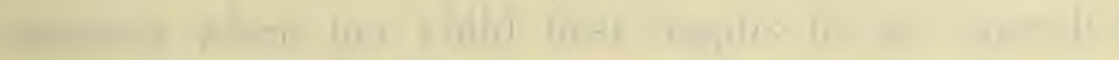
1.

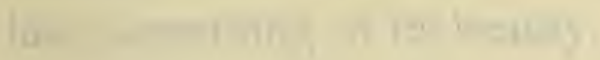


"GOSSIP IS NOT NECESSARILY UNKIND." 


\section{Chapter V}

\section{GARDENS AND GOSSIPS}

W

HEN one reflects how much of life is taken up by talk, what an amount of energy, of toil, is expended in it; how most things hang upon it, how the entire machinery of the world would crash to atoms without it; when one realizes that every second of time is filled with the ceaseless murmuring of millions of voices, why, one begins to understand that talk, just talk, as a habit, a practice, a necessity, exceeds all other human activities in importance, as it certainly does in volume and continuity. Manifold in its variety, it is the one thing indispensable to every one, from the mumbling savage in naked bondage to the earth to the greatest philosopher, from the youngest to the oldest, the wisest to the vainest. Everything we accomplish owes something at least to talk; without it we could not think, and even in our feelings we require its assistance. Our joy is heightened, our sorrow relieved by it. To a mother, the moment when her child first begins to use speech is unforgetable; and love itself, if it were dumb, would lose something of its beauty. 


\section{THE LURE OF THE GARDEN}

Contemplating, then, the stupendous force and preponderance of talk in human affairs, it seems not amiss to devote a few pages to the extolling of the garden's superior advantages as a place for conversation. Naturally there are forms of talk not suitable for the garden-public utterances, lectures, speeches, society small talk-but for gossip, for the confidences of two congenial souls on many topics, for the interchange of intimate reflections, and the musings of two persons content to shut out the rest of the world, for these the garden is emphatically the place, and for these it is constantly being employed.

Gossip is not necessarily unkind; it may be quite as harmless as it is delightful, and ever since there has been a bench behind a cottage in the shade of an arbor, there have been kindly gossips to sit upon it. Under the benign influence of the surroundings, both word and subject will tend to be gracious, and gossip in a garden prove one of the gentlest and most comforting of human exercises.

It begins in infancy-you can watch two youngsters at it, tucked close together in the shade of the ornamental cherry, where their tiny doll's table is set out with acorn-cups and seed-vessel cheeses and a finely fashioned mud-pie. The little mothers have forgotten their fairy feast, however. They are whispering and laughing, telling secrets, pretending all sorts of magic make-believe, giggling rapturously over the I 08 


\section{GARDENS AND GOSSIPS}

humor of life as observed from their own particular standpoint.

Later on, the young girls, back from school on summer holidays, have a world of information to impart to each other in the safe company of the flowers, where no one will intrude upon them. Down there in the arbor under the honeysuckle the two heads bend close together over confidences that are no doubt rather foolish, gaged by our standards, but which are very necessary to the adolescent heart. Not all foolish, either. Some of the talk of these young creatures is filled with fine ambitions and noble dedications. There will be a good deal of silly sentimentality on boys and parties and the pretty frippery of clothes, and why not? But there will also be discussions full of purpose and hope and dawning knowledge. Emerson will get quoted and pages be read aloud in which high matters are spoken of and great aims set. Possibly the tackle forged in these long, intimate chats between a couple of girls, these chains that are so securely to hitch the wagon to its star, will prove frail as silver paper in the coming stress of life. Never mind! The starshine was clear enough for a while, at least, and the two maidens will hardly be able to think, in after days, of the hours in the old arbor without a rush of tenderness. Reality may have turned out to be different from their shimmering forecasts, but they will never regret having made them, or having believed in them. 


\section{THE LURE OF THE GARDEN}

Later on, it is Love that unlatches the gate and betakes himself to the gossip's seat, where he is immediately very much at home. For of the many places where love belongs, a garden stands first and foremost. Lovers belong in gardens, and it is probably the instinctive recognition of this fact that fills the park benches, when his votaries have nothing better in the garden line to shelter in.

A garden in the moonlight, consecrated by the ineffable serenity of the still hour, and breathing an intenser fragrance in the cool freshness following upon a day of heat and sun, verily murmurs of love, so that even the lonely soul most dedicate to a solitary existence is conscious of the influence as he wanders through its mazes. And when it is two young people who find themselves caught in that silver mesh, hands meet and heads lean together as inevitably as a harebell sways on its stalk or a rose opens its crimson beauty at the appointed moment.

The words, the secrets lovers whisper each to each while the clambering moon-flowers pause to listen and the white moths flutter by on love business of their own, this speech of love can never be translated into the language of ordinary life. True enough that the words used are identical with those employed in commonplace affairs and between persons whose hearts are keeping the normal beat. But these same words are full of occult and esoteric meanings, when exchanged by lovers 


\section{GARDENS AND GOSSIPS}

in the silence of the garden's presence, and carry a message quite different from what they bear when upon every-day errands. If he murmurs that he has waited an eternity for this special moment of time, the phrase conveys a meaning not apparently inherent in the simple words themselves; he might address precisely the same remark to his office boy, for instance, and there would be no stirring of divinity in the circumambient air. The Chinese exemplify this peculiar quality in speech more clearly than the rest of the world, for they can say the same thing and give it any of half a dozen or half a hundred interpretations, according to intonation and inflection. Every lover is Chinese enough to be able to talk thus to his beloved in a language of his own, no matter how ordinary the words he uses.

So it is that the gossip of a pair of lovers will not bear repeating, even should it be overheard. It is the most wonderful of all the intimate talks that belong within garden walls, but it is practically unintelligible to every one else, as it is also apt to be entirely confined to the two who are talking, having little or no relation to any other human being or event, even when it wanders into the future and predicts the most exquisite miracles. However, though we cannot understand these whispers and the soft laughter that proceeds from the leafy arbor when lovers occupy the old bench, we ought none the less to be content that such agreeable sounds do occasionally proceed from it, without 


\section{THE LURE OF THE GARDEN}

inquiring too curiously as to their exact value; for at the worst they are apt to be as brief as they are strange.

After the lovers' transient occupancy is over, the seat will not stand empty long. Husband and wife come to it to discuss the manifold issues of their life, from the transplanting of a pansy bed to the building of a new home or the future of a child. Sitting thus, sipping their tea in the midst of the peaceful hush following so pleasantly upon the day's labors and the jarring contact of butcher-boys and wearisome callers, disputes with the "boss" and futile struggles against predatory millionaires, the two chat together, knitting up care's raveled sleave with serenity renewed.

"Mary says she 's going to leave," remarks Madam, alluding to the hardly attained cook. Elsewhere the statement might be tremulous with tragedy; but spoken comfortably from the garden chair, with its convenient arm upon which to set the tea-cup, the announcement is touched with a sense of humor. "What are mere cooks," it seems to intimate, "beside the comedy of their amazing tendency toward perpetual motion?"

As for him, he tells her that the office force is to be increased at last, and informs her that Bennet has a head like a pin, and could n't be trusted to turn a corner; but the remark carries no sense of bitterness. Whatever subject is discussed, only round, pleasant words are spoken; and though the gossiping of these 


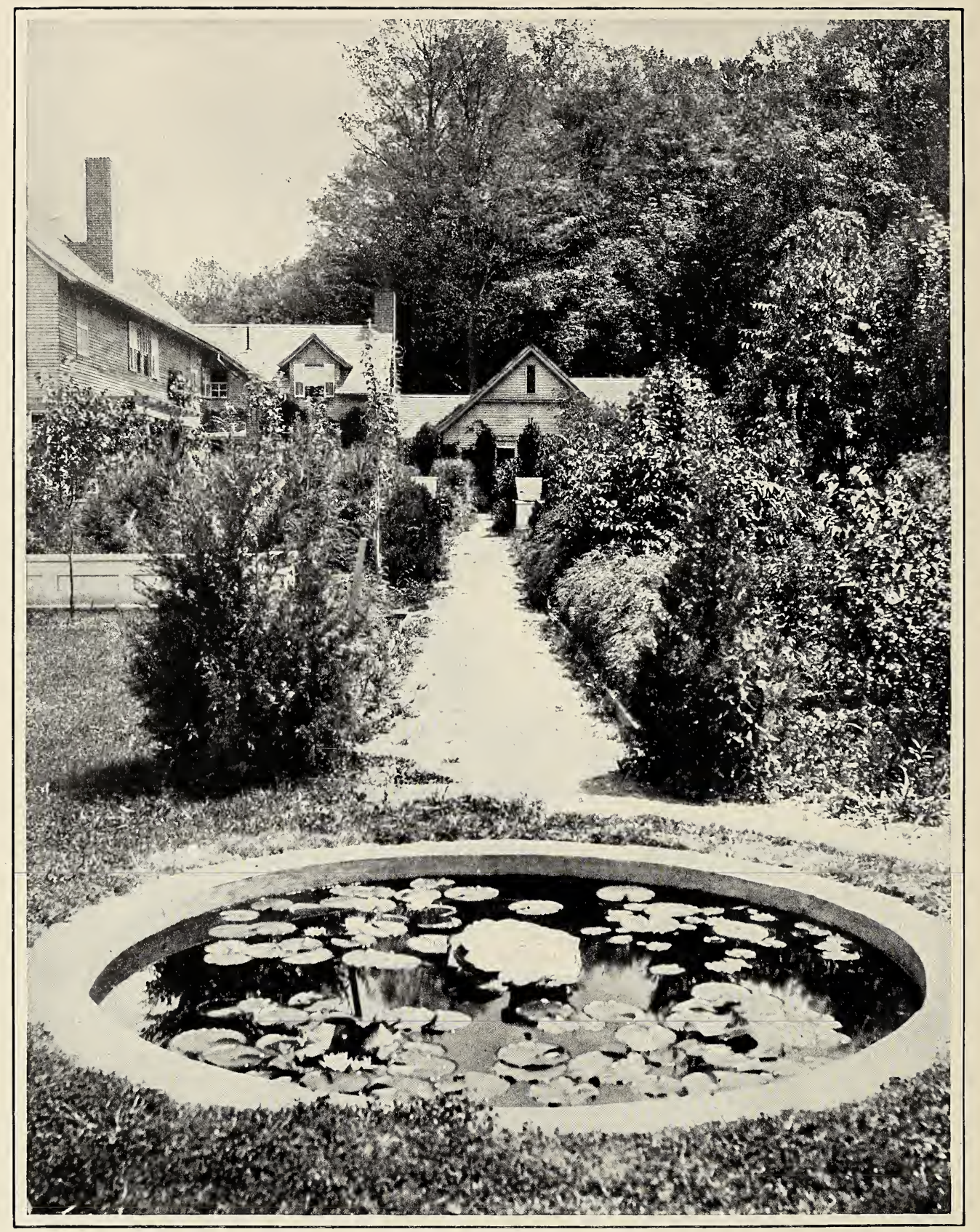

A GARDEN PATH 


\section{GARDENS AND GOSSIPS}

two may not much resemble the lovers' mystery of talk, may indeed confine itself to the most ordinary topics and be entirely understandable of the multitude, yet who shall deny it its own peculiar quality, its note of home? After all, the garden that listened so tenderly to the lovers, need not despise the conversation of this maturer couple, hobnobbing so quietly, and apparently only concerned with servant and office and bread-and-butter problems. Possibly an even deeper miracle lies within this matter-of-fact chatter than the lovers themselves were cognizant of.

But these are by no means all who come to exchange confidences in the shady nook. The whiteaproned nurse-maid and her friend sit here, watching their charges, the rich Irish flowing in an unbroken stream, with Peggy this and Norah that, and "Sure it 's a wonder Tom don't make his meanin' clear," or "' $\mathrm{T}$ is a pretty dress ye had on at mass, Annie, would ye be afther tellin' me where ye got the same?" "Will ye look at the childer, in the middle-midst of the nasturshuns, glory be to God!" Or it may be a hit at a mutual acquaintance: "What, old Mrs. Blake, that lives by the car-track? Well, well, one niver can say what nixt!"

Perhaps, of all the various forms of gossip overheard by the garden, the loveliest is that between a young and an old person who are friends. Real friendship between the generations is rare, but when it exists it is of 


\section{THE LURE OF THE GARDEN}

the finest. That youth is fortunate who can pour his perplexities into the ear of an older man or woman, and who knows a comradeship and an understanding exceeding in beauty the facile friendships created by like interests and common pursuits; and fortunate too the girl who is able to impart the emotions and ideas aroused in her by her early meetings with the world and life to some one old in experience but comprehendingly young in heart. Both of them will remember those hours long after the garden gate has closed behind their friend forever; as long, indeed, as they remember anything that went to the making of the best in them.

Besides all these, with whom the garden is so welcome as the fittest spot for converse, there is another type of gossip to whom the garden is preëminently suited, and that is the old. The old men and women love it; its sheltered sweetness renews their youth for them, and through its haze of green and gold the past shines luminously, warm and fair. There they sit, the two ancient cronies, rather toward the sunny end of the bench, recalling a life, or at least all those pretty acts and happy days that build up, in the memory, a glorified retrospect of life, in which the harsher lines and darker shadows have faded out. For the alchemy of time has the fortunate faculty of preserving what is radiant and happy rather than the reverse; so that the two old friends, preluding their remarks with, "Do you 


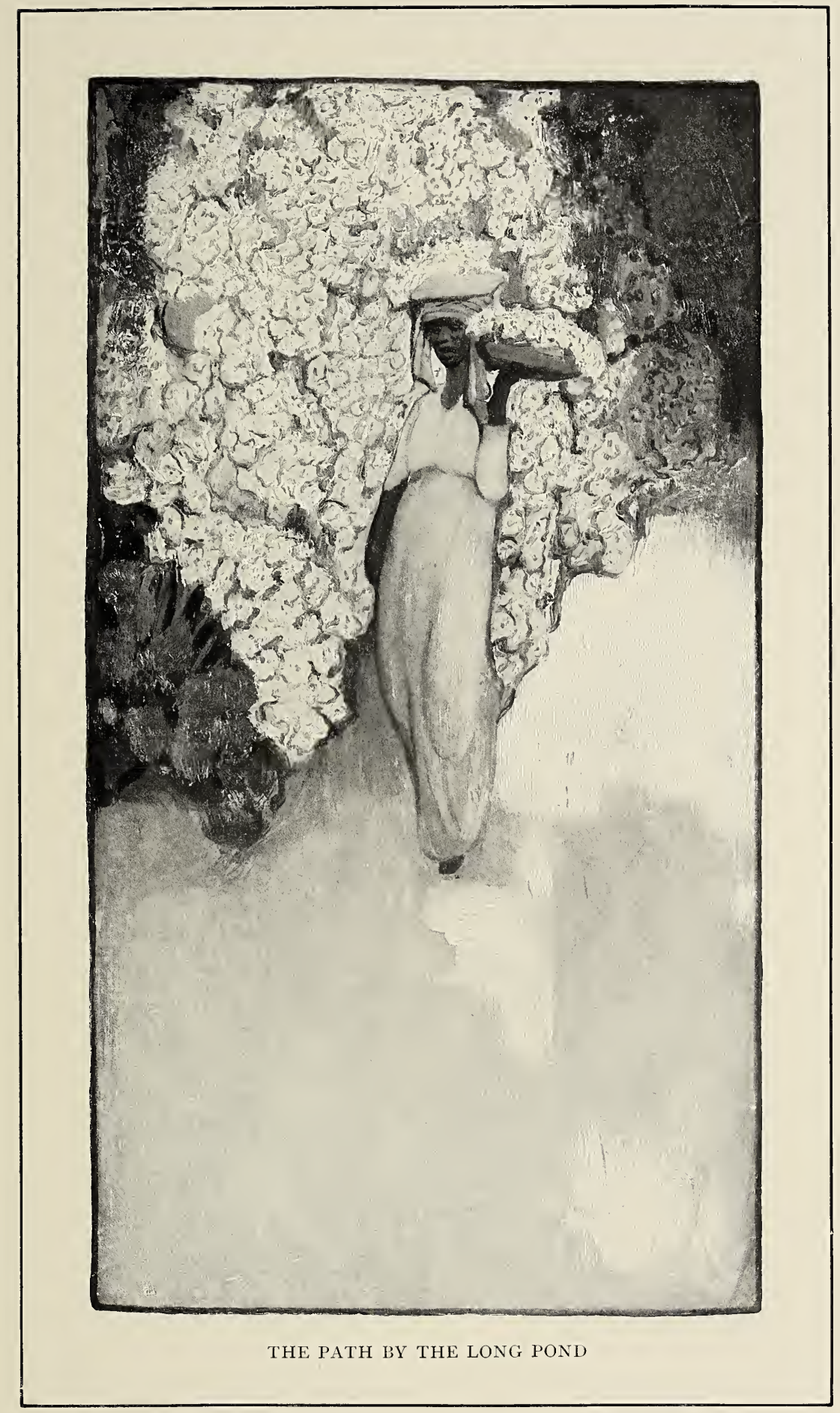





\section{GARDENS AND GOSSIPS}

remember?" will tend to the mention of old jokes, old sweethearts, old triumphs and gay boyish escapades, rather than the disappointments, losses, and regrets the vanished years have dealt them.

So it is that an old garden is full of confidences, and quite as sweet with human hopes and fancies as with the breath of flowers. Odd and tender memories drift about in it, and the thoughts of persons far away will often turn to it, joining the many gentle ghosts that haunt the paths and arbors when the moon is abroad. It is difficult to think of a better thing for a nice ghost to do, so long as it is careful not to disturb the new pair of lovers who have this moment pushed open the gate; a hint we also may do well to observe. 

GARDENS OF SOME WELL-KNOWN PEOPLE 


\section{IN HELENA'S GARDEN}

BY RICHARD WATSON GILDER

Through the garden sunset-window

Shines the sky of rose;

Deep the melting red, and deeper,

Lovelier it grows.

Musically falls the fountain;

Twilight voices chime;

Visibly upon the cloudlands

Tread the feet of Time.

Evening winds from down the valley

Stir the waters cool;

Break the dark, empurpled shadows

In the marble pool.

Rich against the high-walled grayness

The crimson lily glows,

And near, $\mathrm{O}$ near, one well-loved presence

Dream-like comes and goes. 



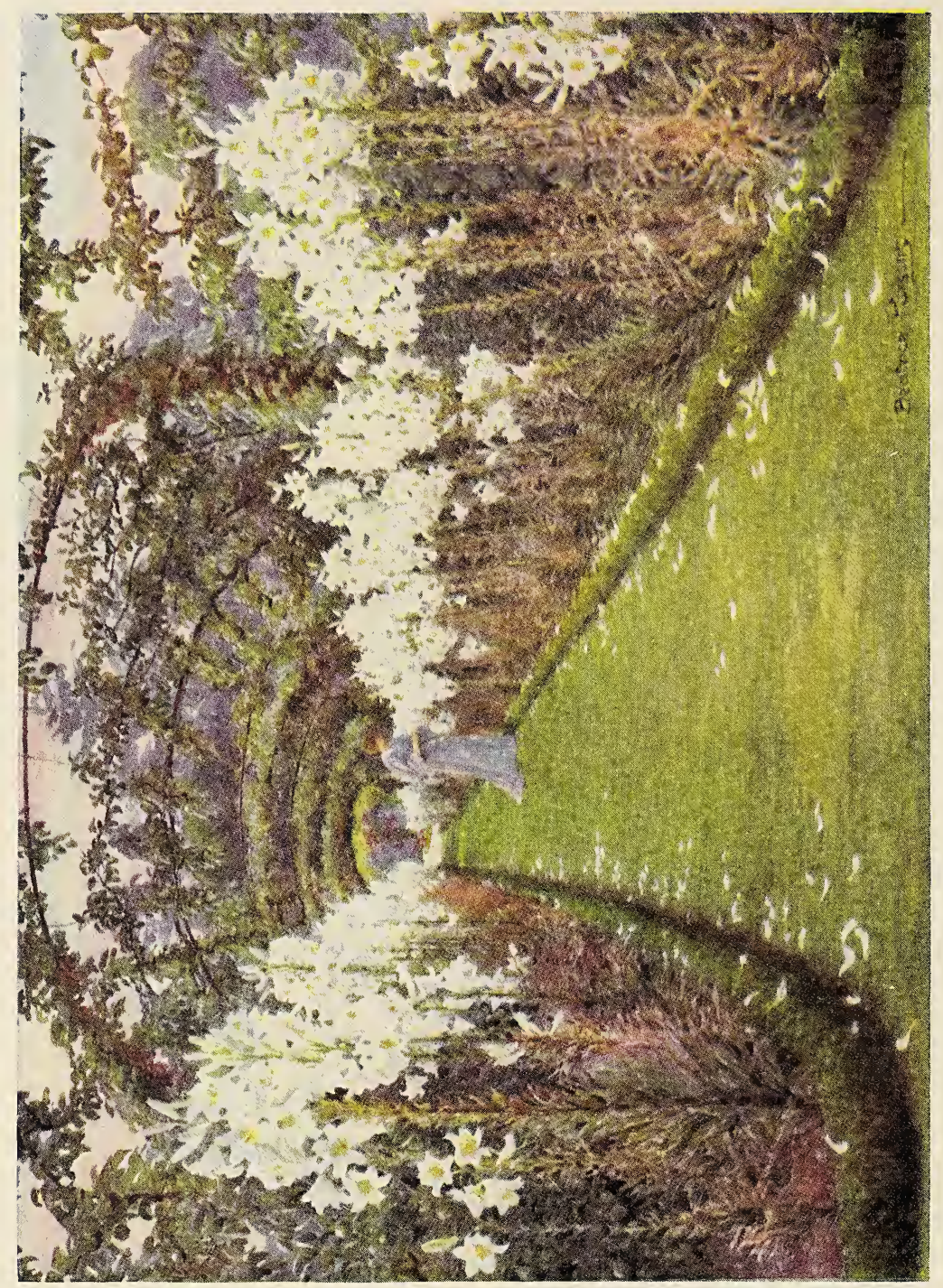




\section{Mininin:}

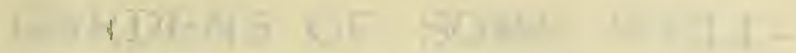 WIOWN plat I}

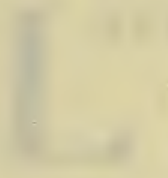

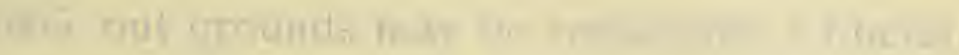

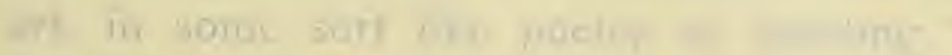

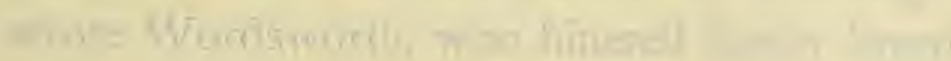

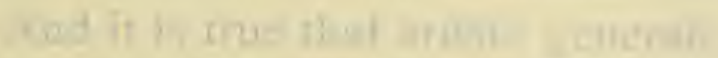

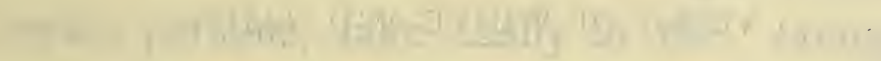

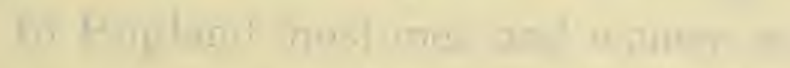

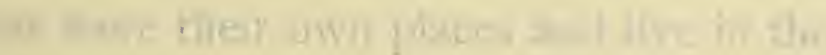

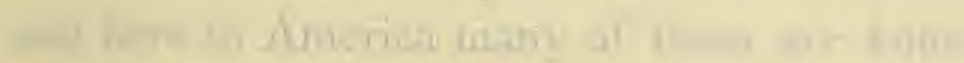

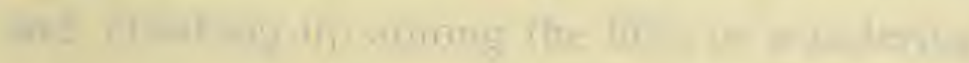

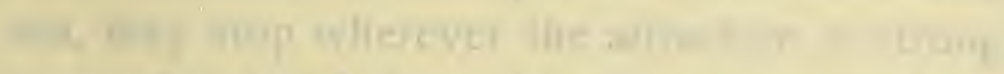

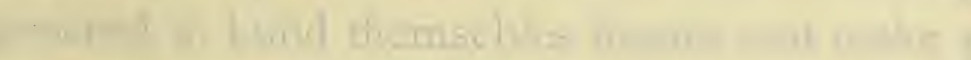

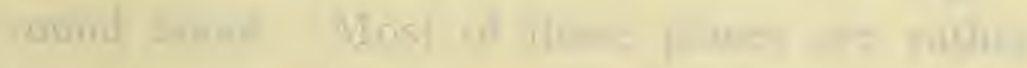

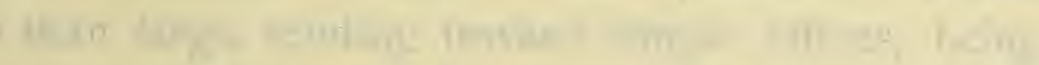

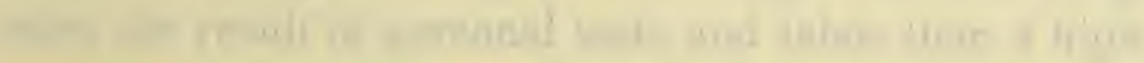

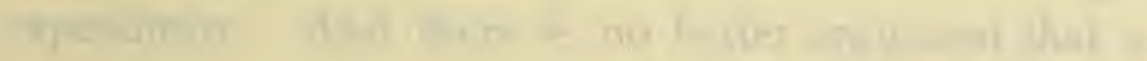

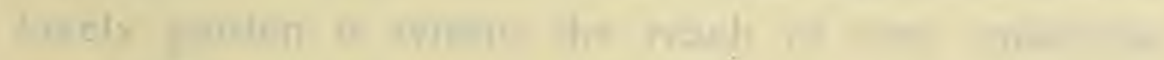
ne

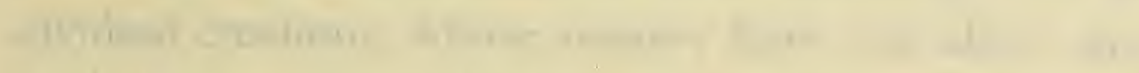

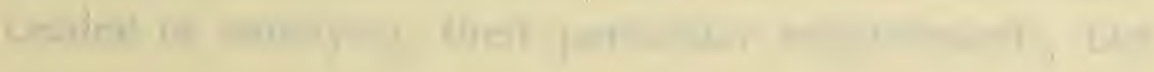
$1: 3=7$ 


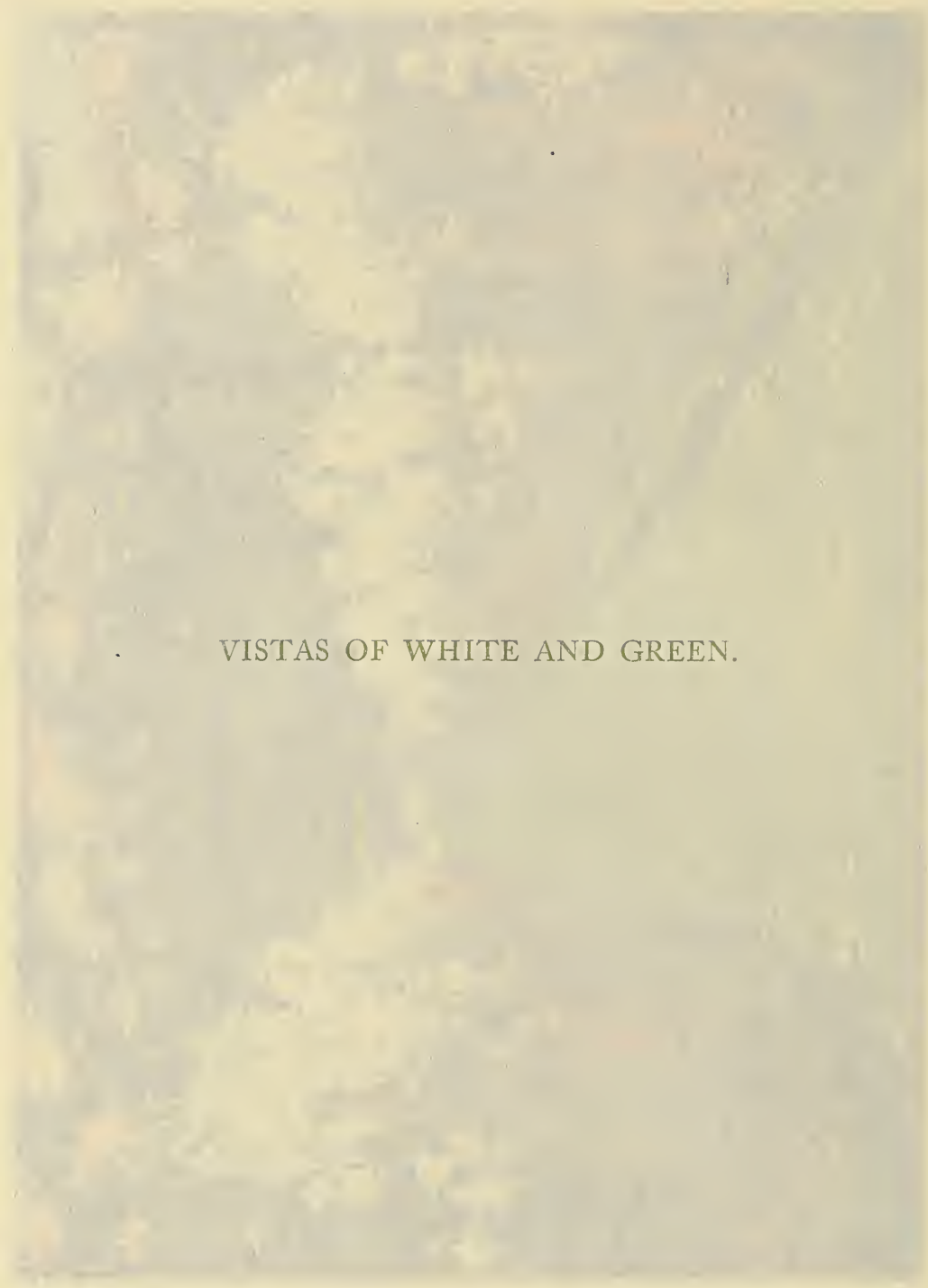




\section{Chapter VI}

\section{GARDENS OF SOME WELL- KNOWN PEOPLE}

“T AYING out grounds may be considered a liberal art, in some sort like poetry or painting," wrote Wordsworth, who himself dearly loved a garden. And it is true that artists generally, as well as literary persons, take easily to the "laying out of grounds." In England most men and women in these professions have their own places and live in the country; and here in America many of them are following suit, and, climbing up among the hills or wandering by the sea, they stop wherever the attraction is strongest, and proceed to build themselves homes and make gardens round about. Most of these places are rather small than large, tending toward simple effects, being more the result of personal taste and labor than a high expenditure. And there is no better argument that a lovely garden is within the reach of very moderate means than a visit to some of these charming and individual creations, whose owners have not alone succeeded in satisfying their particular requirements, but 


\section{THE LURE OF THE GARDEN}

have given excellent object-lessons in suiting house and grounds to each other and both to the surrounding country.

Personality in a garden is as unmistakable as it is in a human being, and as elusive. The garden that expresses personality is rarely the work of the professional landscape artist. It is a quality born only where the man or the woman who loves the place and means to live there plans and contrives and labors to fulfil an individual demand; a garden so constructed contains more than just the stones and green growth that meet the eye, in the same manner that a picture is more than its paint and canvas, or even the cunning workmanship that has skilfully placed the one upon the other. And this personality is precisely the peculiar characteristic of most of the gardens in the midst of which these writing and painting folk have set up their habitations.

Perhaps the best known of such places are those among the Cornish hills in New Hampshire, where a colony of professional people have been building and gardening for some five and twenty years, and have evolved a type of garden that combines something of the flavor of its wild setting with a distinct feeling of home, gardens that are American and at the same time intensely individual. Various they are, some scarcely larger than a tennis-court, and simple as a wild pink; others occupying a considerable space and 


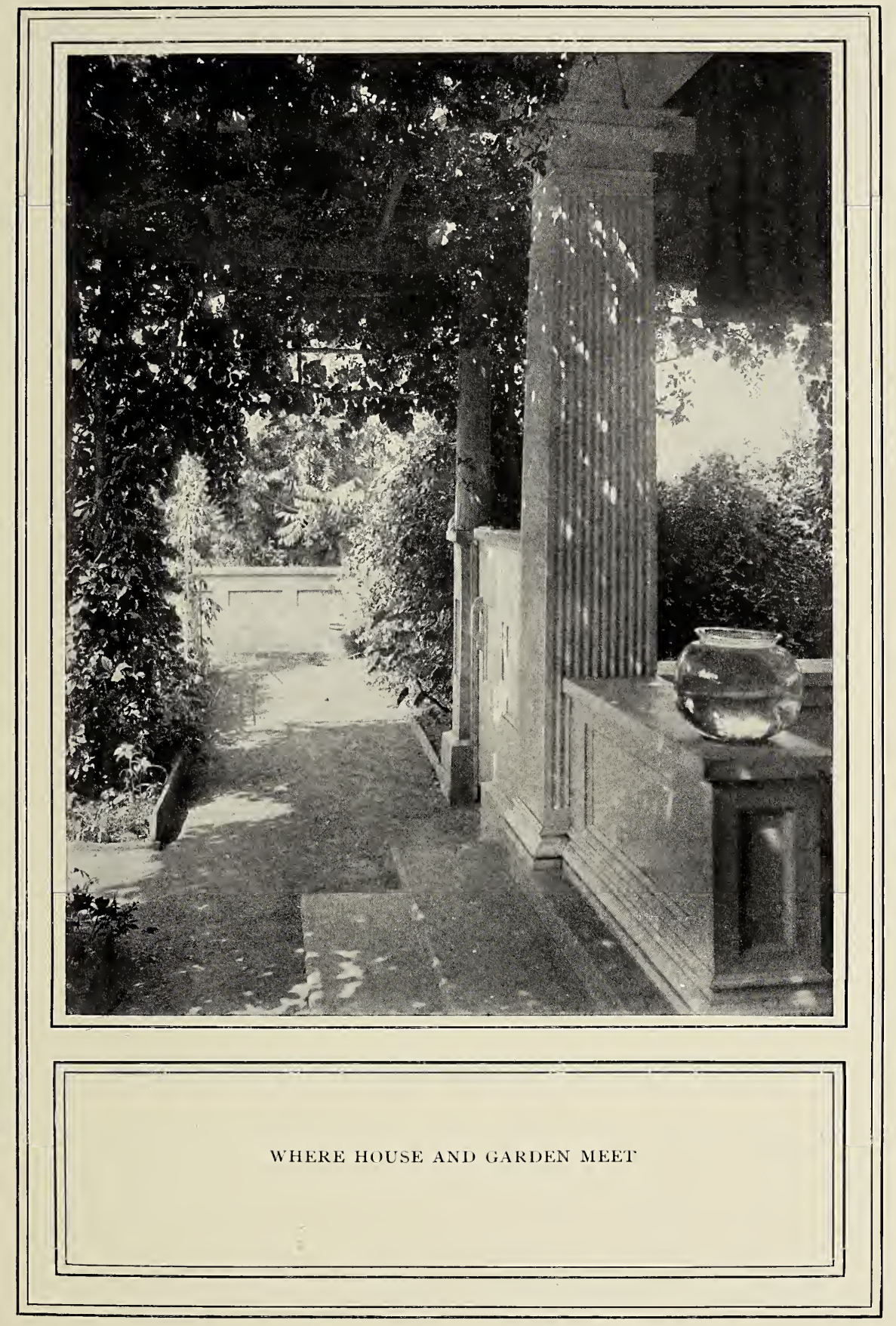





\section{GARDENS OF WELL-KNOWN PEOPLE}

stately with pergolas and marble pools; but none among them handed over to alien builders, any more than the houses were furnished by an interior decorator.

There is Maxfield Parrish's garden, partly inclosed in white walls and dominated by splendid oaks, a garden that is hardly more than a wide walk bordered by snowy spiræa and leading to the loggia, with a few vivid beds whose fragrance blows into the windows; a place more like a handful of exquisitely arranged flowers in a stone vase, augmenting the home feeling and home loveliness, than something apart and important in itself. The house is admirably suited to its situation and the placing of the trees and its hill view are true portions of its garden.

Rose Standish Nichols, on the other hand, has a garden complete in itself, separated from the house by a grass-grown terrace, and inclosed within a rough stone wall, low and broad. The paths cross each other symmetrically, meeting in the center at a clear circular pool, over which an apple-tree spreads its twisted boughs, an old tree dating before the "first resident" among all the artist colony. The beds are long, bordered with grass, and the color scheme is enchanting, changing with the changing seasons, but harmonious always, daring, too, as nature herself is daring. A certain careless, joyful effect in the planting, in the arrangement of the shrubs, the use of fruit-trees, and the irregularity of the gray old slabs that make the wall, mitigate what in 


\section{THE LURE OF THE GARDEN}

less beauty-wise hands might have proved too severe a plan. A great sense of peace pervades this garden, accentuated by the sky-reflecting pool with its encircling benches and sheltering tree.

In quite a different setting is the sea-shore place owned by Cecilia Beaux, at the farther end of Gloucester Point, some three or four miles from the ancient fishing town. The long yellow road that leads to it passes by many a row of drying-sheds where the white cod glisten in the sun, and then on by the radiant bay where children are playing in and out of the water, to where the voice of the almighty ocean sounds a mighty diapason beyond the line of dunes that meet the eye at the Point's extremity. The house is entirely hidden from the road by a tangled thicket of tupelo-trees, a small and somewhat fantastic tree indigenous to the country, whose branches, interlacing overhead, form a continuous canopy of green, under which narrow paths twist and cross, astir with moving shadows. A pool as full of mysterious reflections as a magic mirror lies at the intersection of several of these paths, and as you wander through the miniature forest you are forever conscious of the close companionship of a murmuring brook, continuously heard but only occasionally glimpsed. Wild flowers and birds of many species flourish here, apparently utterly unaware of human proximity; which, indeed, you doubt yourself until the sly path suddenly deposits you precisely at the open 


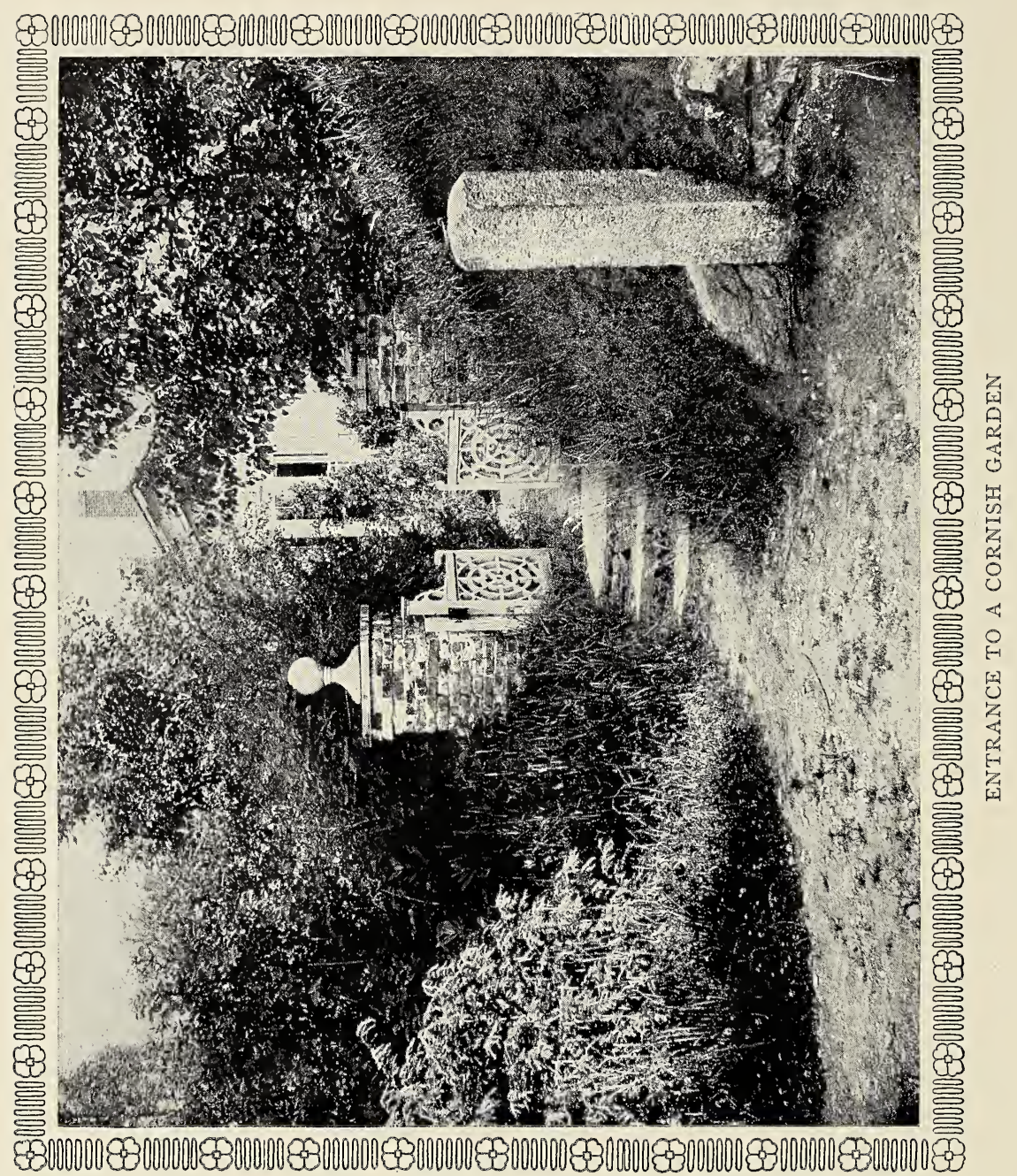




\section{GARDENS OF WELL-KNOWN PEOPLE}

door of a shell-colored cottage, and leaves you to return upon itself into the green shade.

Against the grayish-creamy cottage wall stand lordly hollyhocks, and vines clamber gaily toward the secondstory windows. Cloisters, many-arched, of brick whose pink glows through their whitewash, reach out into the garden; or, possibly, it is the garden that through them attains the house. Climbing roses and clematis outline these arches, while small, vivid blossoms crowd each other in the narrow beds close to the house. Toward the sea, from a terrace floored with brick and guarded by a low and very broad balustrade of stone slabs on short brick pillars, the view lies open to the sky. A lawn stretches down to a wattled fence, over which crimson roses tumble, while above it clumps of larkspur raise their tall spikes, vying with the intense blue of the bay. Where the dense tangle of the little wood ends, other garden flowers grow in a charming, untrammeled fashion, and an ancient carved marble bench or two from Italy wait in an immortal calm for some leisure-loving soul. Practically that is all there is to the garden, but it seems to be as big as the world, it is so entirely sufficient, so wild and yet so petted, so harmonious with the immensities of sea and sky that wrap it round, so intimately connected with the house to which it belongs. A flame of scarlet in the right spot, a tree of noble form, a sense of gentle peace and sure protection, the companionship of house and bosket, 


\section{THE LURE OF THE GARDEN}

lawn and running brook, the purple shadows under the arches contrasting with the green dusk of the wood; many a man has spent his thousands on a vast estate, and never compassed such beauty as this.

Another small garden that is yet great enough to lap the spirit in complete content is the one made by the late Richard Watson Gilder on his place in Tyringham Valley. The house, old, wide-spreading, infinitely homelike, is backed by the uprising hills clothed in pine and hardwood, and faces upon a meadow across the road, through which flows a wild brook bordered by willows. To the left, inclosed within high walls over which the vines hang down, hides the little, infinitely precious flower garden, separated from the rougher elements outside, kept safe as a jewel in a casket. You open the gate straight upon a path that leads to an oblong marble basin brimming with water so clear as to be almost invisible, were it not for the rose leaves afloat upon it. The flower beds are set in a frame of grass, and the walls thick-hung with climbers of many varieties, against which tall, spiky flowers stand primly. The garden is a happy arrangement of straight lines softened by the growth of the plants and the harmony of colors. At one side a charming tea-house shelters a table and a few inviting chairs, a wonderful spot in which to dream away a summer afternoon or to sit in idle conversation with a congenial spirit. When the moon comes into this garden and sets the shadows of 


\section{GARDENS OF WELL-KNOWN PEOPLE}

its encircling trees to weaving curious patterns, it affects you like the conjured marvel of an Arabian tale. A strange hush falls upon it, the hidden blossoms spill out their most potent fragrance, and within the high walls the cup of beauty overflows.

A garden of a different type is the one belonging to Mrs. Wharton, lying nearer to Lenox. Her place commands a magnificent view of the nearer and farther hills for miles, with half a dozen lakes flashing to the sun. The house itself, adapted from an English model that drew from the Italian, dominates a hilltop, and is attained by sweeping drives and surrounded by downdropping lawns shaded by fine trees. On one side there is a rock garden of great beauty, and the shrubbery, curving like an approaching wave, edges the lawns nobly. But it is the double sunken gardens, set down into the hill, that are the distinction of the place. Each has its central fountain, surrounded by geometrically shaped beds separated by narrow gravel paths and planted with brilliant flowers of contrasted hues. At their lower edge stand marble walls in the Italian style, with openings that permit exquisite glimpses of the view, and, at the same time, form a lovely background for a few of the taller flowers and some choice rose-trees.

Looking down upon these two gardens, separated from each other by the terraced lawns, as you stand on the broad veranda of the villa, the glory of their 


\section{THE LURE OF THE GARDEN}

coloring actually vibrates in the sunlight; yet, framed as they are in spacious green, they do not clash with the distant prospect. A sensation of space, even of magnificence, is the controlling factor of the impression produced; but the place lacks the intimate charm of the Gilders' garden, or the one belonging to Miss Beaux, the sense of personal and loving supervision notable in them and in the Cornish places.

This special spiritual quality, however, so difficult to define and yet so essential to the true garden, is by no means restricted to the small estates. Mrs. Gardiner's place at Brookline is redolent of it, large as it is. Her Italian garden, inclosed within rose-hung walls of old brick and stucco, with its vine-grown pergola, its antique statues, and the flaming splendor of its long beds, breathes this intimate charm, as does the spring garden, sheltered behind its high, cool hedges of evergreen, into whose fairy ring April and May bring all their fragrant wealth. And not only these sequestered spots, but the wide-spreading lawns, the treehonored drives, the great banks of rhododendron and sheets of iris, hold fast this garden soul, captured somehow and unmistakable, like music rendered by a great player, where feeling transcends technique while remaining firm-based upon it.

The contrast between the gardens I have been describing and others of their kind with the usual suburban abortion merits consideration. The difference is 


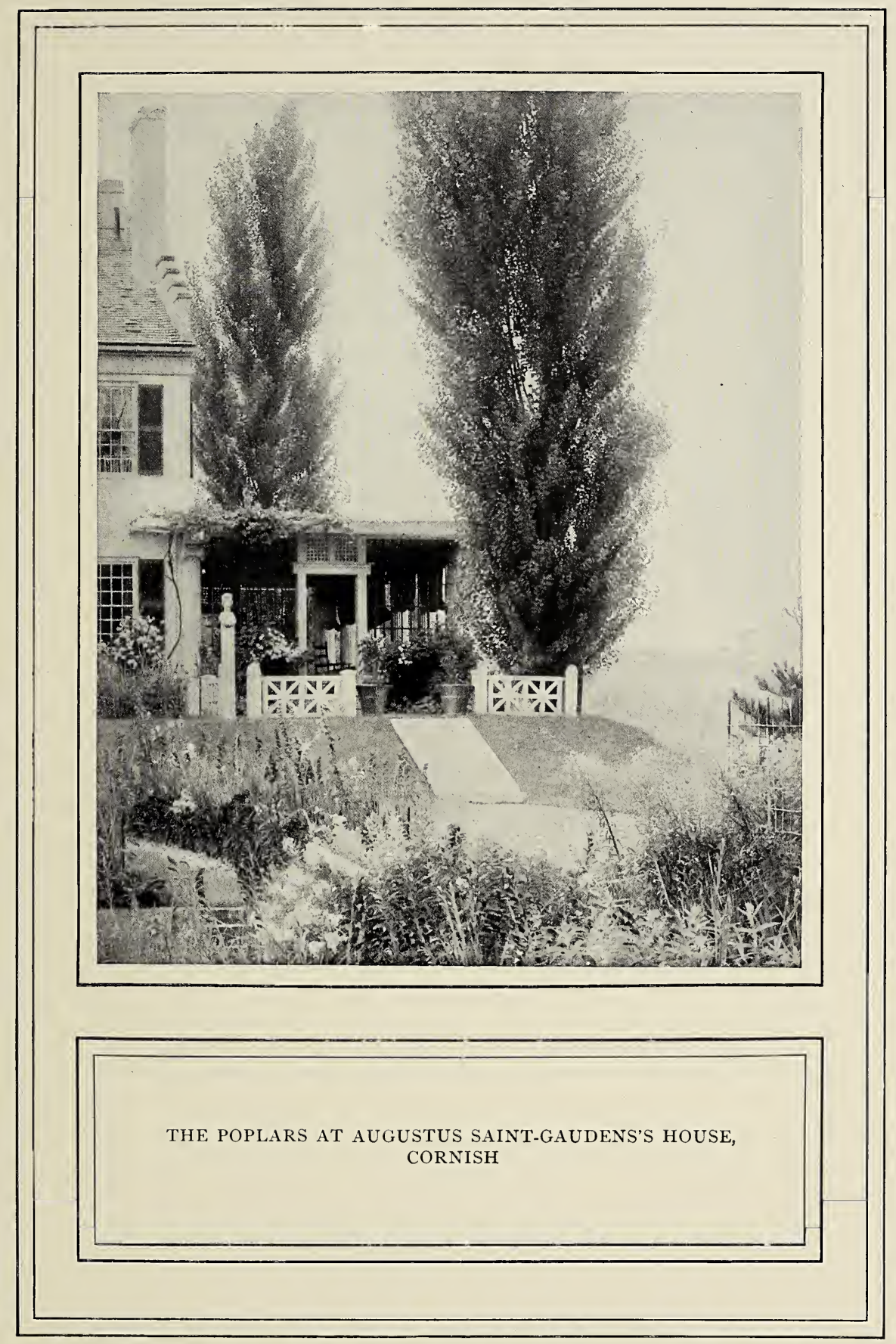





\section{GARDENS OF WELL-KNOWN PEOPLE}

not one of expense. It is not with numberless acres nor an unlimited bank-account that a garden is to be made. Perhaps the only real gardens are those that first took shape in the mind of some one who loved them, and found his joy in realizing them by the actual labor of his hands. At all events, Cornish and Green Alley teach a valuable lesson as well as a lovely one, a lesson good to ponder over and comfortable to learn. 

SOME GARDEN VICES 


\section{THE ROSE}

BY WILLIAM BROWNE OF TAVISTOCK

A Rose, as fair as ever saw the North, Grew in a little garden all alone;

A sweeter flower did Nature ne'er put forth, Nor fairer garden yet was never known:

The maidens danced about it morn and noon,

And learnèd bards of it their ditties made;

The nimble fairies by the pale-faced moon

Watered the root and kiss'd her pretty shade.

But well-a-day! - the gardener careless grew;

The maids and fairies both were kept away, And in a drought the caterpillars threw

Themselves upon the bud and every spray.

God shield the stock! If heaven send no supplies, The fairest blossom of the garden dies. 



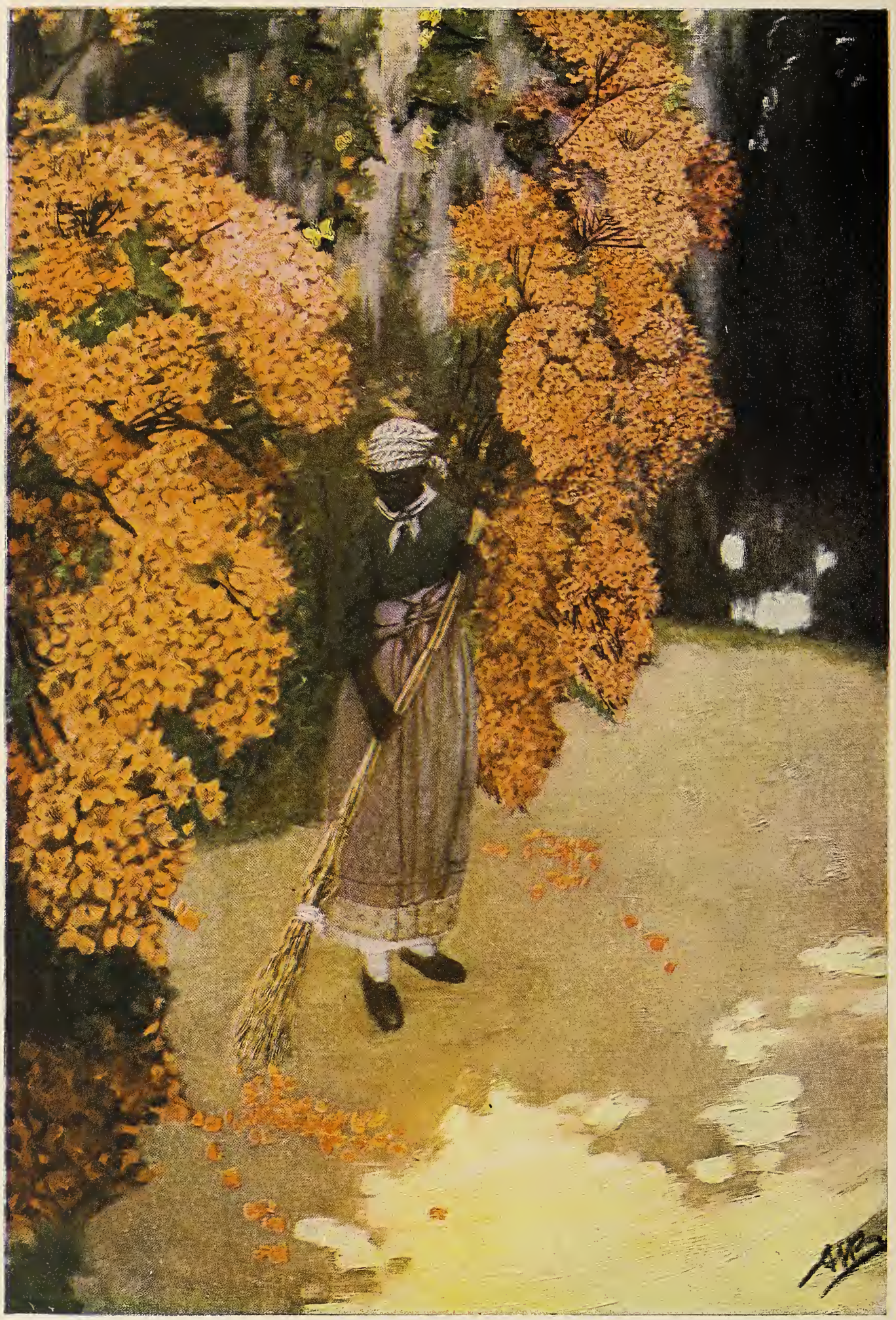


Cins + in

St1MT: int 1,1,

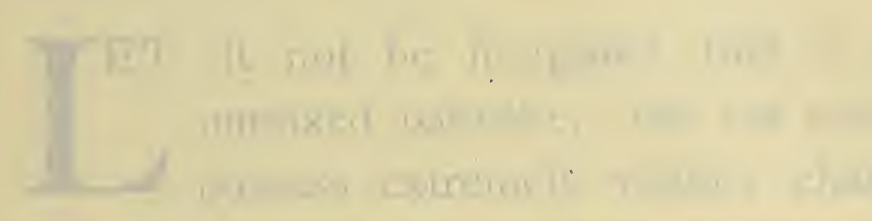

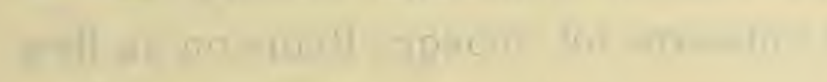

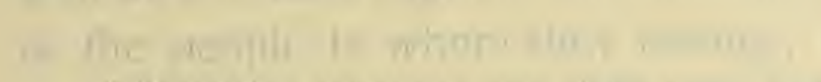

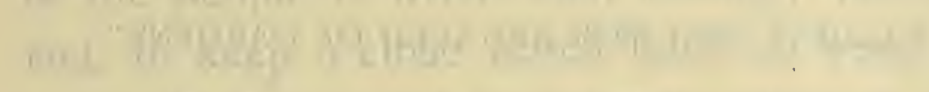

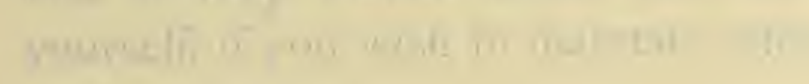

in. (fics, in

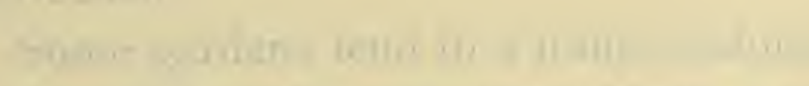

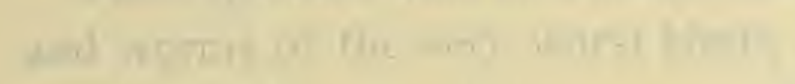

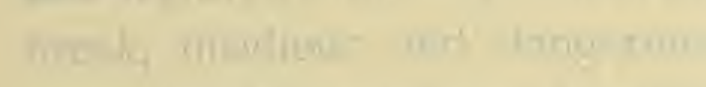

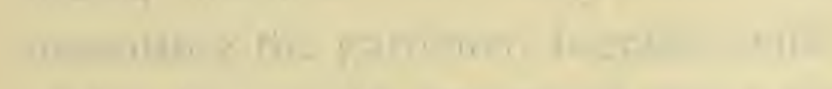

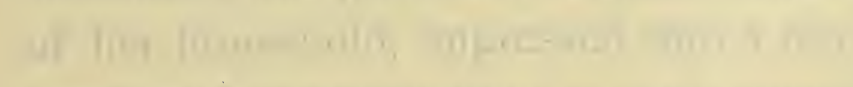

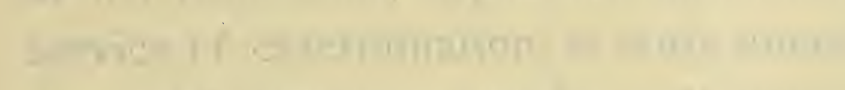

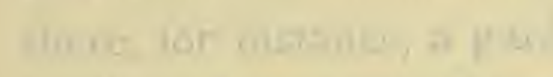

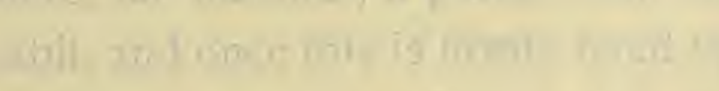

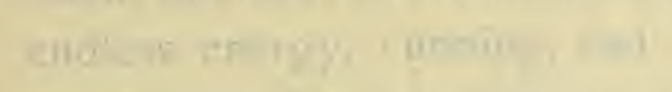

apterna; ine I. $=1, \min$

กิำ $1 \div \frac{1}{4}$

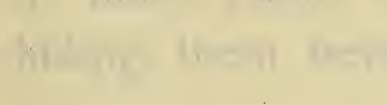


"THE MILDEST AND BEST-BEHAVED OF GARDENS." 


\section{Chapter VII}

\section{SOME GARDEN VICES}

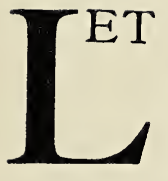

it not be imagined that a garden is an unmixed paradise. On the contrary, gardens possess extremely vicious characteristics, as well as no small capacity for arousing unpleasing traits in the people to whom they belong; you will need, in fact, to keep a close watch both on your garden and yourself, if you wish to maintain either in approximate perfection.

Some gardens tend to a frantic indulgence in insects and worms of the very worst kinds, a habit difficult to break, insidious and dangerous. Their capacity for outwitting the gardener, together with all the members of his household, impressed into a too-often unwilling service of extermination, is truly amazing. Here and there, for instance, a garden will acquire the cutworm habit, and once this is firmly fixed upon it it will display endless energy, cunning, and devotion in finding and pampering these noxious creatures, yielding to them its finest plants and fairest blossoms, sheltering and hiding them beyond your utmost skill to discover, 


\section{THE LURE OF THE GARDEN}

guiding them past your traps and poisons, and in and out of the tin collars with which you have desperately sought to protect your best beloved seedlings. You may be up early and down late, but the garden, working with a feverish frenzy in the service of its enemy, obsessed like a drug fiend with the passion for its own extermination, is more than apt to win in its suicidal intent, and to leave its beds and borders bare of some of its loveliest possessions.

If, however, you do succeed in tracking down and slaying the last of those fat pirates, do not dream that you have conquered your garden's predilections toward evil behavior. It has untold resources of wickedness, and once it has set foot upon the broad pathway of destruction, marches merrily along, undeterred by warnings and examples.

One of the mischievous delights of a thoroughly corrupt garden is to fill all its roses with a horrid yellow and greenish beetle, so that, should you bend to smell or to pluck one of these queen flowers, crimson, yellow, or white, a mass of scrabbling, long-legged, and hardshelled insects begin to agitate themselves, crawling out upon your nose or hands, while the half-blown petals tumble shamefully to earth, corroded and gnawed beyond recognition.

Lacking these, there are myriads of infinitesimal but hateful creatures which a garden, smiling deceitfully from its multicolored faces, will diligently hang on twig 


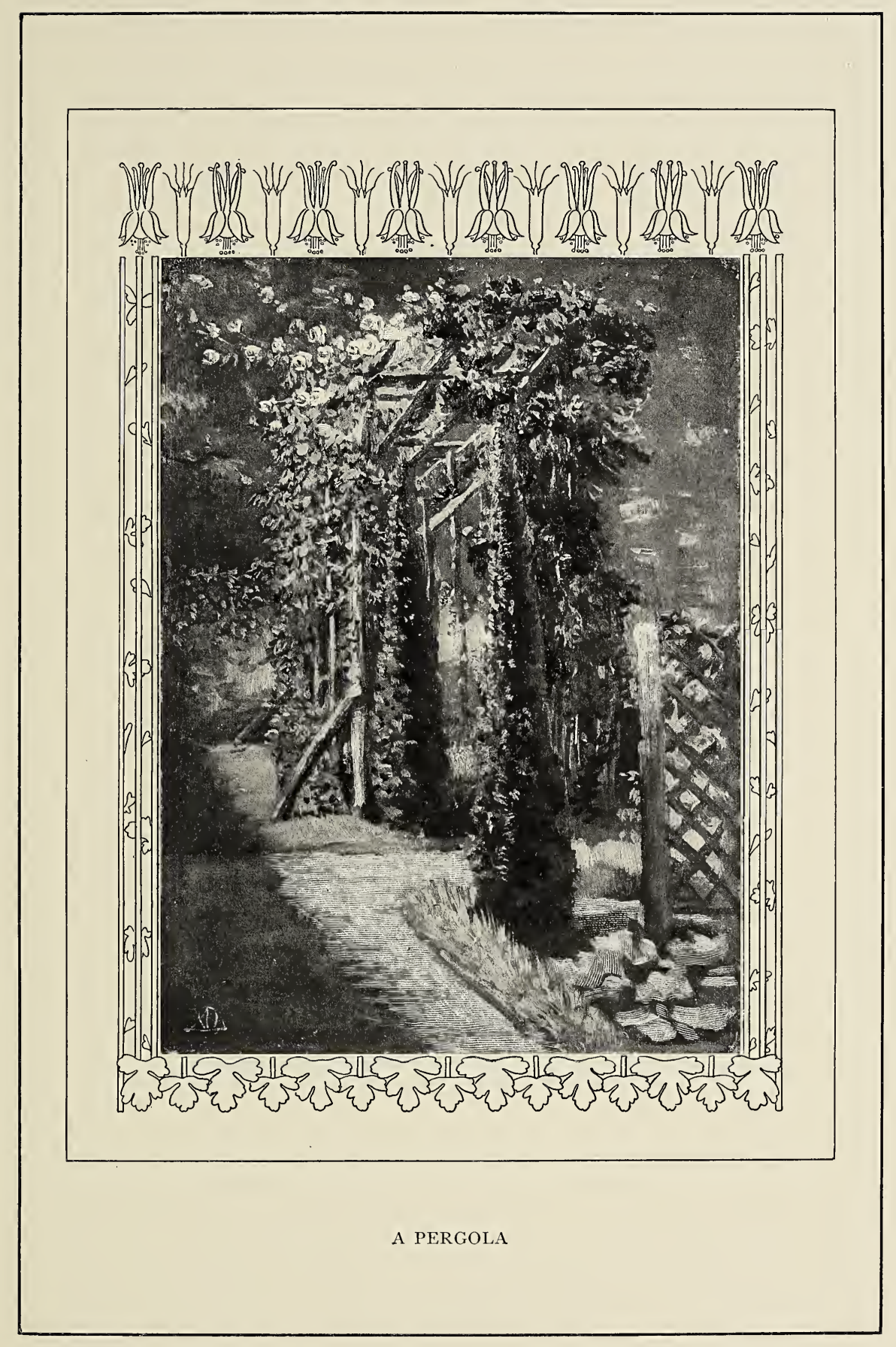





\section{SOME GARDEN VICES}

and stalk, staining the insects a harmonizing green or brown, so that they are not to be distinguished until, seizing the stem of a sweet-pea or a poppy, your hand makes a smeary mess of myriads, each of which has been sucking the life juice from the plant it helps to encumber. Even the mildest and best-behaved of gardens is liable to sudden lapses, to hideous indulgences. Sometimes you are tempted to believe that only the gardener is ever aware of the power and the omnipresence of evil. Some gardens simply turn lazy. Encourage them, prod them, feed them, and water them as you will, they retain an obstinate inertness. They grow nothing, they do nothing, they gape shamelessly in your face throughout the radiant summer. Or else they turn to weeds. Weeds are, of course, a constant temptation to gardens, even those of the strongest character and finest manners. Hardly any garden but will devote twice the time and trouble to raising some particularly ugly weed than it can be induced to bestow on the up-bringing of your loveliest annuals or most carefully cherished perennials. Human mothers are said often to prefer their misformed or wayward children to the good and beautiful ones. Gardens reveal this trait to a dismaying extent. The pity and love shown to its ugliest weed by the average garden is touching, if it were not so infuriating. It will spare no pains to convey to this voracious plant all the delicately prepared food destined for your lilies or your 


\section{THE LURE OF THE GARDEN}

phlox, will discover the utmost art in draining its water toward the thick roots of its favorite, give it sun and shadow, sweat and labor for it. If you snatch the hateful progeny from its arms, leave only the slightest portion of root behind, and that patient, devoted garden will nurse the battered and wounded thing back again to life and health, to flaunt triumphantly in bed and border.

Foiled of its propensities for bugs and weeds, a garden has other ways of annoying you. Sometimes it manifests what looks like the healthiest interest in developing whatsoever plants you give it to the lustiest growth imaginable; but it confines this growth to leaf and branch, allowing not so much as one tiny floweret to appear. At other times it turns its attention to frustrating your color schemes, changing everything magenta, or bursting out in screaming yellow where you had planned a heavenly harmony of blues. Again, refusing to grow grass in the circle around the sun-dial, it assiduously struggles to bring it up in clumps and patches in the paths. Occasionally, a garden will become addicted to a spindly habit. Plant what you will, everything shoots up on long, sickly stems, with wads of leaf and pale flowers high in the air. Or possibly it will take a contrary direction, and shrubs that ought to bear up bravely will lie lankly on the ground, while even sunflowers and hollyhocks show short and squat of limb. 



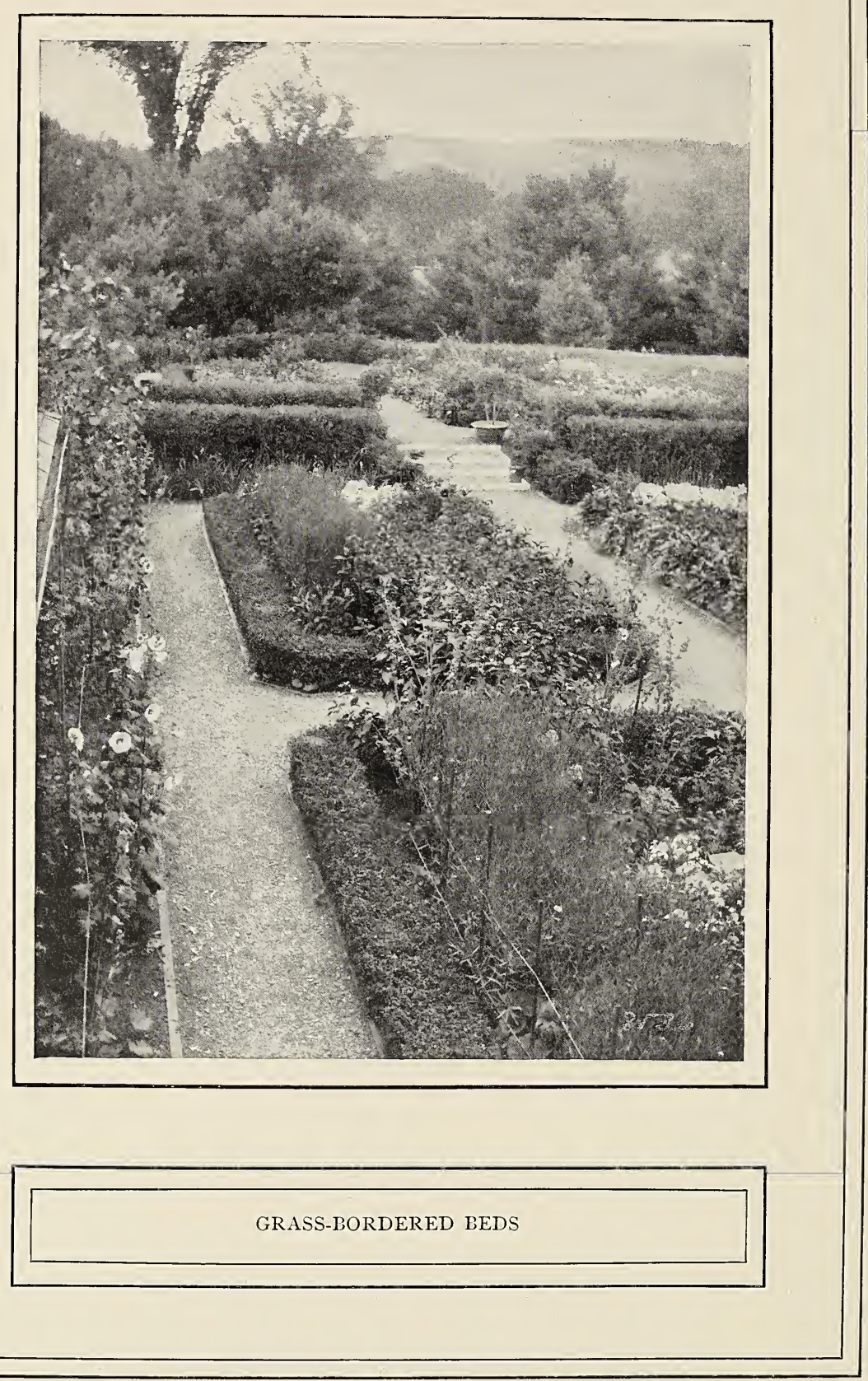




\section{SOME GARDEN VICES}

But not only the garden is delivered over to a multitude of sins. The gardener is by no means exempt. There are gardeners that are among the most trying specimens of humanity, crammed with cantankerous ways and a heavy cross to those with whom they come into constant contact. The grumpy and short-tempered gardener is one of the fixed characters of fiction, the gnarled old man, despotic within his hedges, treating the most legitimate intruder into his domain like a thief or a murderer, and regarding the wishes or the commands of his employer as beneath contempt.

But beside this complete specimen of garden depravity, there are acquired vices that seize upon the most amiable, undermining and wrecking the noblest. Chief among these is the garden annual, or nursery and seed-catalogue habit. Persons have been known to develop this pernicious vice to such an extent that no other literature is allowed in their house, and the discussion of any other subject tabooed. The arrival of a new bunch of these highly colored and disingenuous publications is feverishly awaited, and, once in hand, a slave to this habit cannot be lured away from their perusal. Business, domestic ties, and the sweet uses of society, all fall before the tyrant. Hour after hour the victim is to be seen bent over the pages, marking them up with occult signs, turning down corners, cutting out segments, and writing dozens upon dozens of letters concerning the items thus distinguished. 


\section{THE LURE OF THE GARDEN}

Should one of these miserable catalogues be mislaid, the entire household is turned upside down. Unkind accusations and violent reproaches are poured out on the various members of the unhappy family; the lost catalogue, it appears, contained data of the highest importance, priceless scribblings on the margins, information and observation worth their weight in gold. Despair and suspicion reign until the thing is found; and the difficulty of finding a lost magazine or catalogue is one of the awe-inspiring, unexplainable facts of existence. There is no spot too small for it to crawl into, no place so obvious but it can lie there unobserved. If there is a fire within reach, it is certain to have betaken itself into the hottest portion, and to have spared no pains in getting its important parts burned. If there is an old closet to be found that has not been opened for years, it is invariably discovered to be jammed with such lost publications, though naturally such discovery is not made until the time of its usefulness is past.

Another peril in the seed-annual habit lies in the depression itsindulgence is sure to bring about. No amount of experience teaches their victim that they are pure fiction, based on a perverted imagination, of lying and unstable character. The pictures they contain, like the text that babbles rapturously through them, have no relation to the actual product of root and seed as they are planted in earthly gardens. Yet, season after season, their 
. 


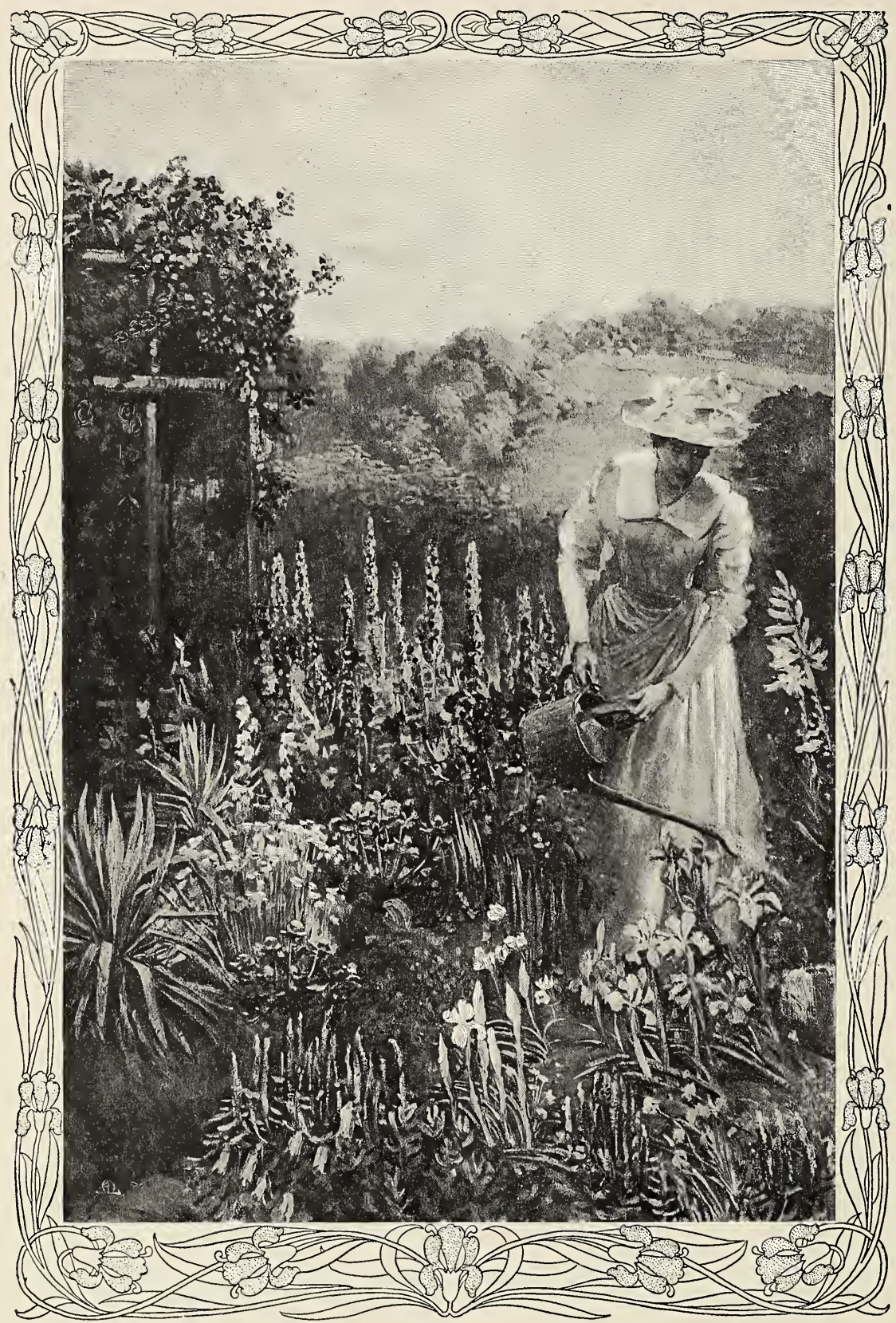

A JULY EVENING 


\section{SOME GARDEN VICES}

hypnotized purchaser, lured on and befuddled by his obsession, buys and sows, plants and digs, and waits in tremulous anticipation for the consummation so confidently predicted in his favorite quarterly. And season after season the unashamed truth looks up at him from his carefully tended beds, beautiful in its own way, doubtless, but what a different way! Where is the gaudy glory promised by the shiny page? Where the immense spread and height of leaf and flower, the dahlias reaching to the dining-room windows, the moon-flower covering the entire wall of the house, the solid bank of yellow poppies, the foot-long spires of mignonette?

Woe upon printed deceit! Instead of the lush growth of branch and many-tinted flower, a shy, conservative bloom rewards your expectations. Many of the dahlias have elected to open in a one-sided manner, as though reluctant to leave the bud for the full ear; the moonflower has devoted most of its length to the ground, refusing the proffered assistance of wire netting to lift it skyward-and so with the rest, for, oh! the difference between nature and art.

There are other failings to which the amiable among garden folk are subject, different small vices, harmless enough, it may be, but capable of arousing extreme bitterness of soul in those who must endure their consequences. Their name, indeed, is legion, and it were an impossible task to enumerate them all. But a few stand out with a certain salience and merit mention, not 


\section{THE LURE OF THE GARDEN}

so much with the hope of their being avoided, for they are usually incurable, but simply as more or less interesting phases of human weakness or depravity.

There is the man who believes every one else to be as hipped as he himself over the immature processes of his garden, and who routs out his luckless guest in the dim, damp hours of dawn to show him a series of utterly uninteresting squares of soil, while the dew, as he expresses it, "is still pearling each leaf and flower." This admiration of dew is a disagreeable trait found in many otherwise reasonable gardeners, and is capable of leading them into the worst excesses of early rising, with a consequent moving forward of the breakfast hour that necessitates every one being dressed for the day by half-past six at the latest.

This type of man will drag you out through the wet grass, and balance you on narrow, slippery paths while he points out minute bits of green, designating them by Latin names that you do not understand. If you inadvertently set a heel on some absurd two-leafed driblet of a plant, he bounds to the assistance of the flattened seedling with a shriek of dismay, shouldering you into a puddle with a vicious twist of the shoulder. Of course you apologize, and he receives the apology; but at breakfast he is gloomy, and when your hostess inquires whether you did n't find the garden looking very promising, he replies, with a palpably forced hilarity, "Sam 's a great gardener, he is. Managed to flatten out an 


\section{SOME GARDEN VICES}

entire row of my finest delphiniums with one stamp of his foot-gad, what a foot!"

There is another garden criminal whose special prey is his own kind. This is the habitual borrower, the man who is forever coming to get something that he has either lost, neglected to buy, or broken. Persons with this vice have been known actually to snatch the lawn-mower, the spade, or the hose from your very grasp, carting them over to their own place with a mumbled ejaculation that they will return it in "no time." Evidently this division of time never arrives; at least, if you want your tool, you must go for it-to find it lying out in the sun and rain, rusty, forgotten. This sort of man will sit on your back porch and study your catalogues, and growl because you don't subscribe to more. He will ask for slips and plants, hint that his pinks and snapdragons have disappointed him, and demand a bunch of yours- "you always have such luck." Neither walls nor hedges will keep this pest out, nor any amount of denial discourage him. Early and late you may hear his "I wonder if you could let me have -," resounding through the violated peace of a garden you can no longer call your own.

The selfish gardener, he or she who will not pick any of the lovely inhabitants of their beds, is rarer, is few and far between, but does exist. These go along their paths with snub-nosed scissors that clip the dead blossoms but never the living ones. They gloat over 


\section{THE LURE OF THE GARDEN}

the perfect blooms; but no pleading eyes or outstretched hands will persuade them to the sacrifice of a single flower. And their garden, howsoever riotous of color and sweet odor, has a shadow upon it, a chill at its heart that all the sunshine in the world cannot quite dispel.

But, really, most garden vices are absurd, even attractive failings, at which you can afford to smile however you may suffer by them. Gardeners are usually gentle folk, a little queer, possibly, a bit given to unusual hours and odd enthusiasms, and rather careless of more important matters-such as Wall Street and ocean travel-but harmless after all, and even in their worst moments easy to placate with a package of seeds or a few roots. Their most obsessing sin, perhaps, is proselyting, and a narrowness of view that divides the world, for them, into simply two classes, the gardening and the non-gardening. But, with all their faults, they are a lovable class, and they are inveterately happy. 
GARDENS IN LITERATURE 


\section{AN ENGLISH GARDEN}

BY SIR WILLIAM MASON (I 772 )

But swift, with willing aid, her glittering green Shall England's Laurel bring; swift shall she spread Her broad-leafed shade, and float it fair, and wide, Proud to be called an inmate of the soil. . . . Nor are the plants which England calls her own Few, or unlovely, that, with Laurel joined, And kindred foliage of perennial green, Will form a close-knit curtain. Shrubs there are Of bolder growth, that, at the Spring's first call, Burst forth in blossomed fragrance. Lilacs robed In snow-white innocence or purple pride, The sweet Syringa, yielding but in scent To the rich Orange, or the Woodbine wild That loves to hang on barren boughs remote Her wreaths of flowery perfume. These beside Myriads, that here the Muse neglects to name, Will add a vernal lustre to the veil. 



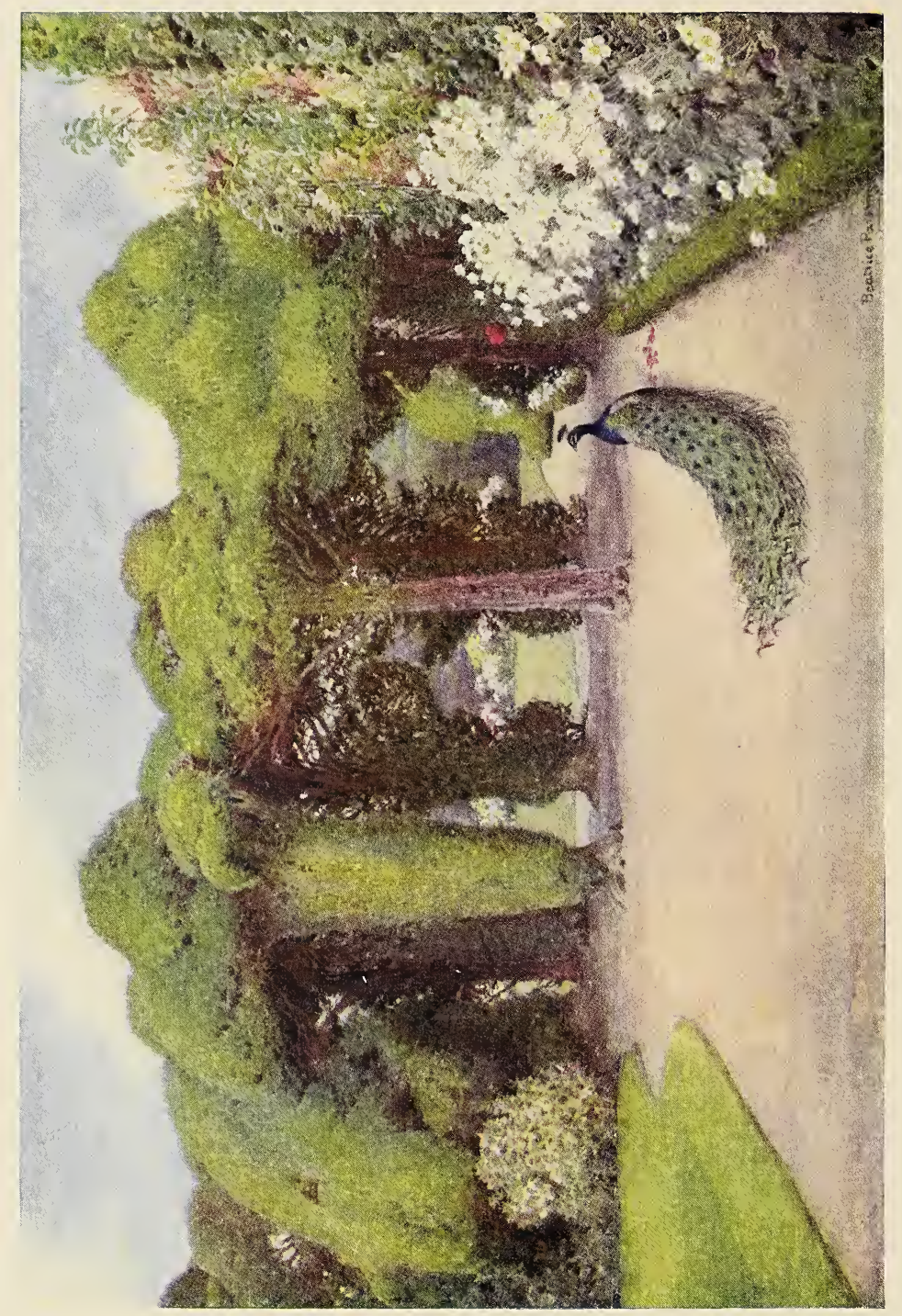




\section{$x^{2}+2+2+1$

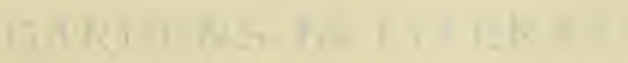

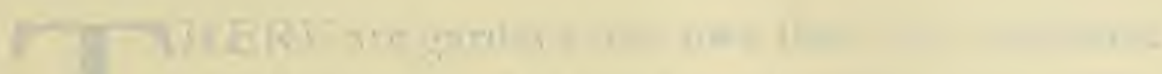

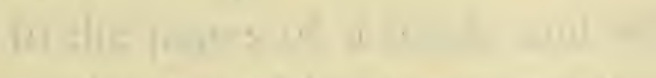

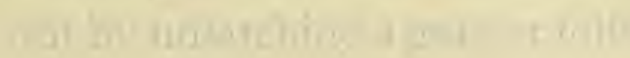

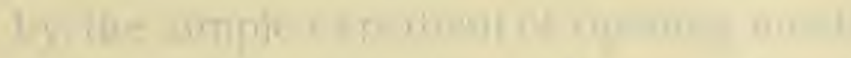

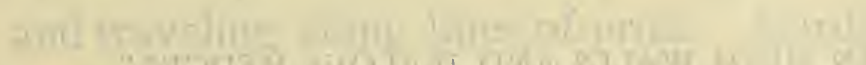

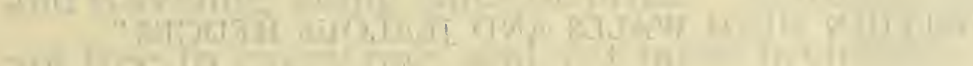

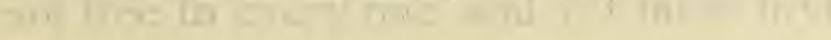

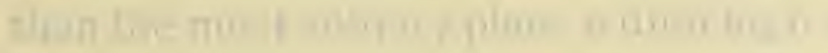

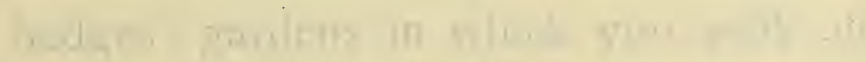

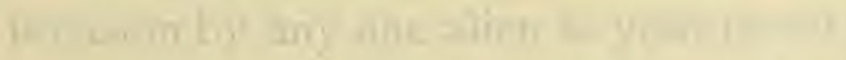

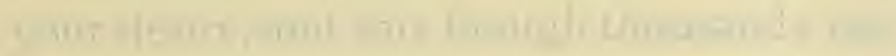

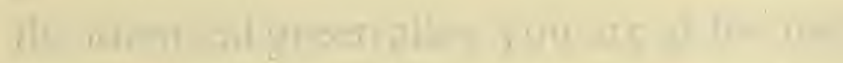

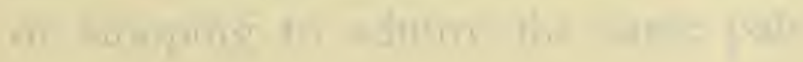
promy

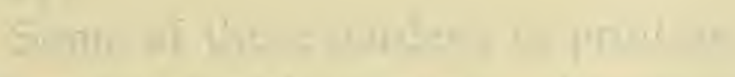

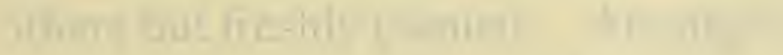

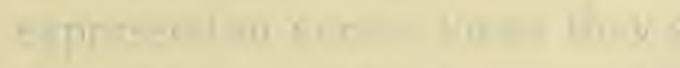

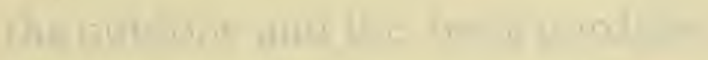

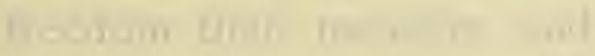
35.

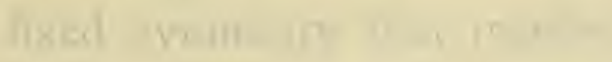





\section{Chapter VIII}

\section{GARDENS IN LITERATURE}

$7 \mathrm{HERE}$ are gardens that owe their sole existence to the pages of a book, and which you enter,

1 not by unlatching a gate or following a path, but by the simple expedient of opening an attractive volume and traveling along lines of print. Gardens, these, that are free to every one, and yet more inviolably secluded than the most solitary place within high walls and jealous hedges; gardens in which you walk alone, safe from invasion by any one alien to your mood or unknown to your desire, and this though thousands may be treading the identical green alley you are at the moment following, or stooping to admire the same pale rose or glowing poppy.

Some of these gardens in print are very old indeed, others but freshly planted. Among the oldest many are expressed in verse; for as they grow more modern both the outdoor and the book gardens tend toward a greater freedom than measure and rhyme allow, the former assuming a more natural habit and departing from a fixed symmetry that insisted on doubling every path,

$$
\text { I } 65
$$




\section{THE LURE OF THE GARDEN}

grotto, flower-knot, and fountain, and the latter making use of the vernacular with all the liberty of a man at his ease.

Bacon is among the first who presents us with a prose garden, setting forth his ideas on the subject with that precision and careful squaring of corners, that attention to detail so dear to his heart, both the garden and himself being decidedly formal. For even in the wilderness, or desert, as he calls it, which he includes, to be sure, being a man of too great a spirit not to realize both its charm and its value, one is conscious of a severe control. He begins by stating the planting of a garden to be the purest of human pleasures and the final product of civilization, and he says furthermore:-

"I do hold it, in the royal ordering of gardens, there ought to be a garden for all the months of the year; in which, severally, things of beauty may be there in season." After enumerating many shrubs and flowers fit to plant in such a garden, where, "if you will, you may have the Golden Age again, and a spring all the year long," and discoursing delightfully of fragrant blossoms - "because the breath of flowers is far sweeter in the air (where it comes and goes like the warbling of music) than in the hand," he shapes his garden for you to see.

"The garden is best to be square, encompassed on all four sides with a stately arched hedge . . . this hedge I intend to be set upon a bank, not steep, but gently slope, of some six foot, set all with flowers . . . I would also 


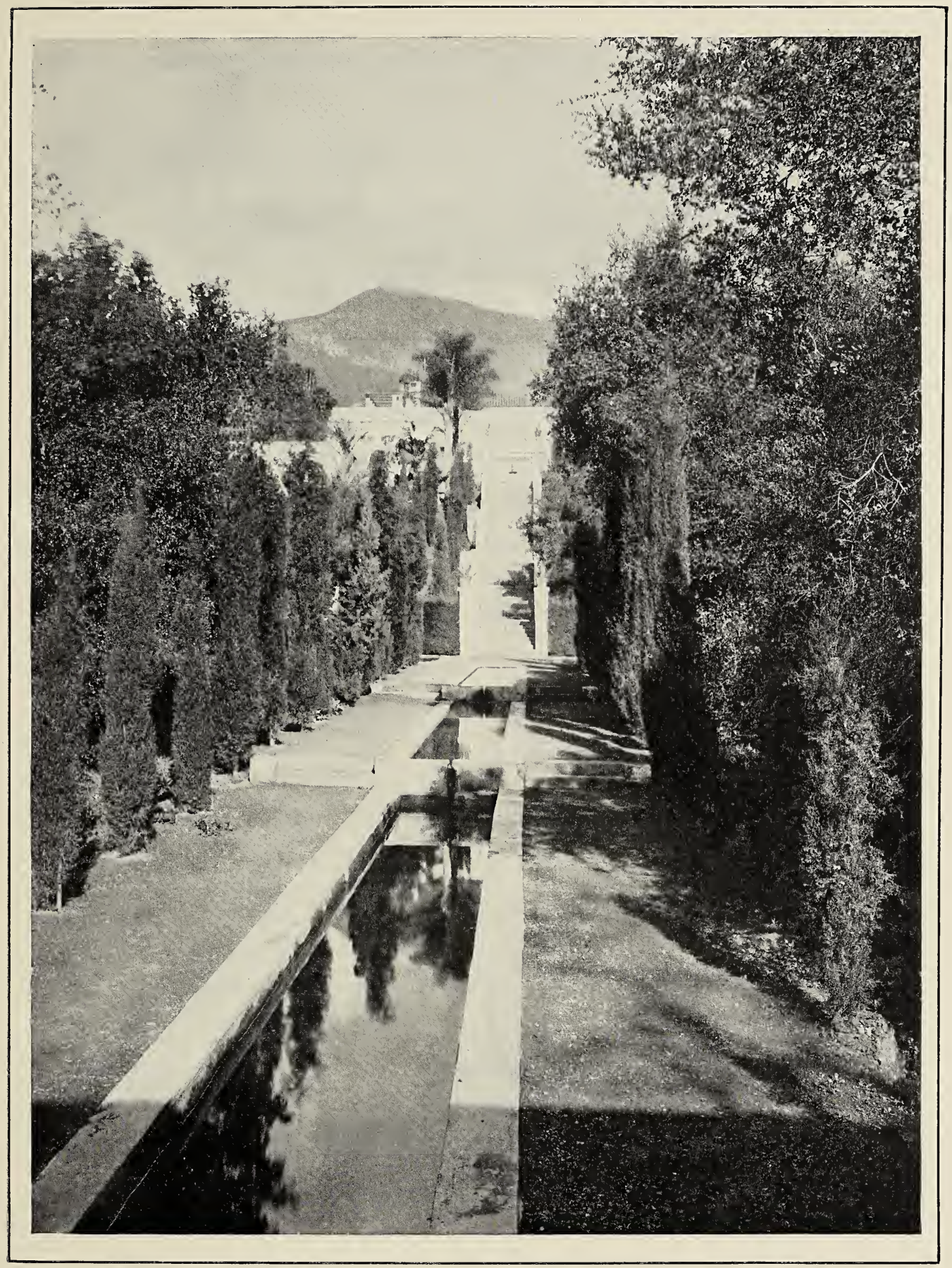

TERRACES AND POOLS IN A PERSIAN GARDEN 



\section{GARDENS IN LITERATURE}

have the alleys spacious and fair. . . . I wish also, in the very middle, a fair mount, with three ascents and alleys, enough for four to walk abreast. . . . For fountains, they are a great beauty and refreshment; but pools mar all, and make the garden unwholesome, and full of flies and frogs."

This garden was to be divided into three portions, "a green in the entrance, a heath, or desert, in the going forth, and the main garden in the midst, besides alleys on both sides." Nothing, he tells us, is more pleasant to the eye than green grass kept finely shorn. And as for the heath, he would wish that "framed, as much as may be, to a natural wildness. Trees, I would have none in it, but some thickets made only of sweet-briar and honeysuckle and some wild vine amongst; and the ground set with violets, strawberries, and primroses, for these are sweet and prosper in the shade."

A sweet place enough, stately and spacious, full of English posies and safeguarded from inroad by those tall arched hedges, all bespeaking an Elizabethan magnificence.

Some fifty years later Sir William Temple wrote his delightful book on the gardens of Epicurus, as well as many others, all over the then known world. But it is when he comes home again that he gives his most charming picture, and falls into his chiefest rhapsody.

"But after much Ramble into Ancient Times and Remote Places, to return Home and consider the Way 


\section{THE LURE OF THE GARDEN}

and Humour of our Gardening in England, which seem to have grown into some Vogue, and to have been so mightily improved in Three or Four and Twenty Years of His Majesty's reign, that perhaps few countries are before us; either in the elegance of our Gardens or the number of our Plants. . . . The most perfect Figure of a Garden that ever I saw either at Home or Abroad was that of Moon-Park in Hertfordshire; it was made by the Countess of Bedford, esteemed among the greatest Wits of her time and celebrated by Doctor Donne." His Majesty was William III, with whom Temple was on the most friendly terms; and the doctor is the poet whose tuneful numbers have beautifully expressed both his admiration for the countess and her garden. Sir William continues his praise of the latter as follows:-

"Because I take the Garden I have named to have been in all kinds the most beautiful and perfect, at least in the Figure and Disposition, that I have ever seen, I will describe it. . . . It lies upon the side of a Hill, but not very steep. The length of the House, where the best Rooms, and of most use and pleasure are, lies upon the breadth of the Garden, and the great Parlour opens upon the middle of a Terras Gravel-walk that lies even with it, and which may be as I remember about three hundred Paces long, and broad in Proportion, the Border set with Standard Laurels, and at great distances, which have the Beauty of Orange-Trees out of Flower and Fruit; from this 


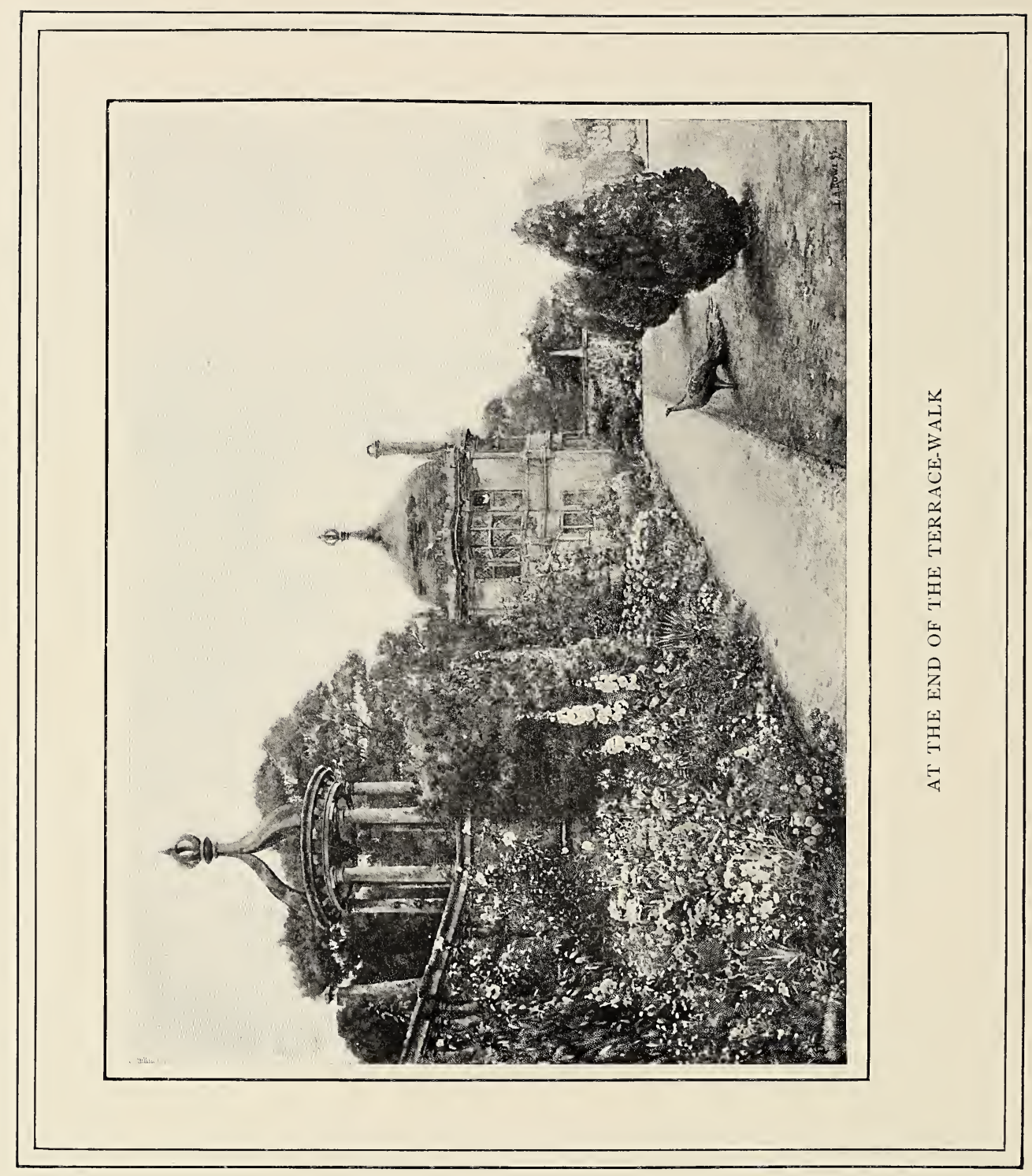




\section{GARDENS IN LITERATURE}

Walk are three Descents by many stone Steps in the middle, and at each end, into a very large Parterre. This is divided into Quarters by Gravel-walks, and adorned by two Fountains and eight Statues; at the end of the Terras-walk are two Summer-Houses, and the sides of the Parterres are ranged with two large Cloisters, open to the Garden, upon Arches of Stone .. paved with Stone, and designed for Walks of Shade, there being none other . . . from the middle of this Parterre is a Descent of many Steps flying on each side of a Grotto that lies between them, into the lower Garden, which is all Fruit-Trees ranged about the several Quarters of a Wilderness which is very shady; the Walks here are all green, the Grotto embellished with Figures of Shell-Rockwork, Fountains, and Water-works ... very wild, shady, and adorned. . . . The sweetest Place, I think, that I have seen in all my Life . . the remembrance of what it is too pleasant ever to forget. . . ."

There is more in the same vein; of terraces floored with lead and stone, and other odd contrivances, little fitting with our conception of a garden, but very alluring and delightful as the old baronet speaks of them. A hundred years later we get a totally different impression, when Hazlitt bursts forth in praise of certain TeaGardens in Walworth, the which he knew in childhood:

"I see the beds of larkspur with purple eyes," he cries, "tall hollyhocks, red and yellow; the broad sun- 


\section{THE LURE OF THE GARDEN}

flowers caked in gold, with bees buzzing round them; a wilderness of pinks and hot-glowing peonies; poppies run to seed, the sugared lily, and faint mignonette. ..."

And before Hazlitt comes Horace Walpole, upholding a "Natural Taste in Gardens," and ridiculing the geometrical designs that had so inspired the admiration of Temple. "The compass and square," he says, "were of more use in plantation than the nurseryman. The measured walk, the quincunx, and the étoile imposed their unsatisfying sceneries on our royal and noble gardens. Trees were headed, and their sides pared away; many French groves seem green chests set upon poles. Seats of marble, arbours, and summer-houses terminated every vista, and symmetry, even where the space was too large to permit its being remarked at one view, was an essential ... knots of flowers were more defensible, subjected to the same regularity. 'Leisure,' as Milton expressed it,-

$$
\text { ... In trim Gardens took his pleasure! }
$$

In the gardens of Marshal de Biron at Paris, consisting of fourteen acres, every walk is buttoned on each side with flower pots, which succeed in their seasons. When I saw it, there were nine thousand pots of Asters. . . ."

Looked at through print, those measured walks buttoned by flower-pots, the trim hedges and green chests 


\section{GARDENS IN LITERATURE}

set on poles, and knots of flowers in regular display, seem quaintly attractive and most fitting with the dress and manners of their day; just as the conscious wildwood tangle of the eighteenth-century garden suited the sentimental artificiality and Rousseausimplicity that masqueraded in a silk and satin homespun.

In our own day, or but little removed from it, a garden now only to be seen in the pages of a book is that described in E. V. B.'s "Days and Hours in a Garden." The foundation of this place was sufficiently ancient, having been known to Evelyn, in whose writings it finds an appreciative mention, but when the Boyles came into possession, all that was left of the old garden were "two symmetrically planted groups of elms in the park field .. a square lawn laid out in flower beds ... a broad terrace walk, old pink walls with stone balls on the corners, two or three wrought-iron gates in the wrong places . . . with a few pleasant trees."

Month by month we see the garden change, increase in beauty: "Close-trimmed yew hedges eight feet six inches high and three feet through ... yews cut in pyramids and buttresses against the walls, and yews in every stage of natural growth . . . borders filled with the dearest old-fashioned plants. . . . Instead of the stable-yard turf and straight walks and a sun-dial and a parterre... green walks between 


\section{THE LURE OF THE GARDEN}

yew hedges, and flower borders. Beech hedges, and a long green tunnel ... nooks and corners and a grand, well-shaded tennis lawn, and, crown of all, the 'Fantaisie,' ... . where all my favorite flowers grow in wild profusion. . . ."

Through the changing seasons we are led along the green paths and by the borders of this gracious garden, and watch each fresh addition and new blooming plant -a place of continual enjoyment, secure of sunshine through even the wildest of winter nights.

There are other gardens in literature, built up entirely from fantasy and dream. Such an one is that where Rappaccini's Daughter breathes in the subtle poisons with which she is so fatally charged. Of this garden we are told: "There was the ruin of a marble fountain in the center, sculptured with rare art, but so wofully shattered that it was impossible to trace the original design from the chaos of remaining fragments. The water, however, continued to gush and sparkle in the sunshine as cheerfully as ever . . . all about the pool into which the water subsided grew various plants, that seemed to require a plentiful supply of moisture for the nourishment of gigantic leaves, and, in some instances, of flowers gorgeously magnificent. There was one shrub in particular, set in a marble vase in the midst of the pool, that bore a profusion of purple blossoms, each of which had the lustre and richness of a gem; and the whole together made a show so resplendant that it seemed enough to I 76 


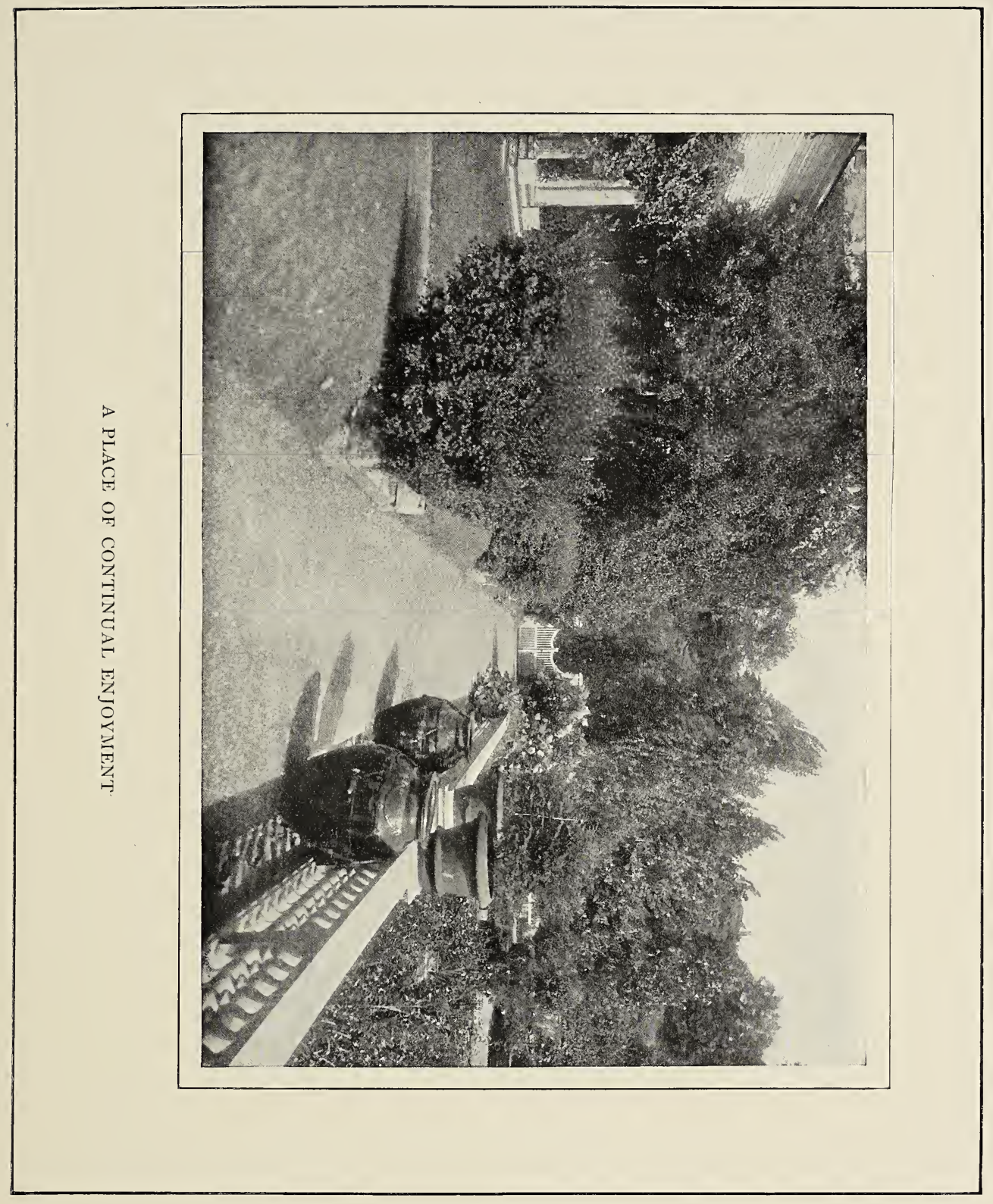





\section{GARDENS IN LITERATURE}

illuminate the garden, even had there been no sunshine. Every portion of the soil was peopled with plants and herbs, which, if less beautiful, still bore tokens of assiduous care . . . some were placed in urns, rich with old carving, and others in common garden pots. Some crept serpent-like along the ground or climbed on high, using whatever means of ascent was offered them. One plant had wreathed itself round a statue of Vertumnus, which was thus quite veiled and shrouded with a drapery of hanging foliage, so happily arranged that it might have served a sculptor for a study.'

A garden of death, nevertheless, this gorgeous consummation of color and poison, as poor Beatrice was to discover.

In "Sesame and Lilies," a garden blows that is, of course, no garden, having nothing to do with "hot-glowing peony" or "faint mignonette," nor with green alley or fountain; but one reads the essay on "Queen's Gardens " with much the same quality of refreshment as is derived from the actual thing; for it is a spiritual garden of which Ruskin writes, and every true garden appeals to the spirit even more than to the senses:

"The perfect loveliness of a woman's countenance can only consist in that majestic peace, which is founded in the memory of happy and useful years,- full of sweet records; and with the joining of this with that yet more majestic childishness, which is still full of change and promise;-opening always - modest at once and 


\section{THE LURE OF THE GARDEN}

bright, with the hope of better things to be won, and to be bestowed. There is no old age where there is still that promise - it is eternal youth."

And the following:-

"She grows as a flower grows, - she will wither without sun; she will decay in her sheath as the hyacinth does, if you do not give her air enough; she may fall, and defile her head in dust if you leave her without help at some moments of her life; but you cannot fetter her; she must take her own fair form and way, if she take any . . . to be, within her gates, the center of order, the balm of distress, the mirror of beauty. . . ."

Gardens and gardening, in all their manifestations, have from time immemorable aroused the philosophic mind to pertinent musings, resembling in this the effect of a softly glowing woodfire ; and it might be interesting to trace the varieties of reverie excited by these different means, as well as the relative value of the conclusions attained by their aid.

"My Summer in a Garden," by Charles Dudley Warner, sums up a number of moralizings concerning men and things, including woman, for most of which the garden is responsible; nor are they any the less wise for being steeped in his warm humor, as were his beans and squashes in the warm ardor of the sun. Among other matters he decides that "perhaps, after all, it is not what you get out of a garden, but what you put into it that is the most remunerative. What is a man? A question I 8 o 


\section{GARDENS IN LITERATURE}

frequently asked, and never, so far as I know, satisfactorily answered. He commonly spends his seventy years, if so many are given him, in getting ready to enjoy himself. How many hours, how many minutes, does one get of that pure content which is happiness? I do not mean laziness, which is always discontent; but that serene enjoyment, in which all the natural senses have easy play, and the unnatural ones have a holiday. There is probably nothing which has so tranquilizing an effect, and leads into such content, as gardening. By gardening I do not mean that insane desire to raise vegetables which some have, but the philosophical occupation of contact with the earth, and companionship with gently growing things and patient processes; that exercise which soothes the spirit and developes the deltoid muscles. . . . In half an hour I can hoe myself right away from this world, as we commonly see it, into a large place. . . the mind broods like a hen on eggs... I begin to know what the joy of the grapevine is in running up the trellis, which is like the joy of a squirrel in running up a tree... we all have something in our nature that requires contact with the earth."

A good deal of healthy philosophy was developed in that German garden planted by Elizabeth in a couple of volumes that bear a lot of visiting, rather a salty and vigorous philosophy, but well soaked in fun. And there are countless other records of the wisdom found in the cultivation or observation of growing things in ordered ways, 


\section{THE LURE OF THE GARDEN}

from Omar's Persian "Look to the blowing Rose about us . . ." to the sage reflections of a "Commuter's Wife."

Unlike any other garden in any other book is the one told of in Barrie's "Little White Bird," where one finds not only such astonishing things as the "Hump" and the "Baby's Palace," and the wonderful map with Round Pond in the center, but one's own childhood, miraculously alive and merry, hardly a stranger and more beautiful than one would have believed. Other magic gardens there are, in Arabian tales and fairy stories, all of them joyful places to know and to visit; but the last garden we will enter is a compromise between magic and reality, being that one made by Count Anteonion the edge of the Sahara, where Domine went to live with her child after her love story was finished, as is told in "The Garden of Allah."

"She stood on a great expanse of newly raked smooth sand, rising in a very gentle slope to a gigantic hedge of carefully trimmed evergreens, which projected at the top, forming a roof and casting a pleasant shade upon the ground. At intervals white benches were placed under this hedge . . there were masses of trees to the left, where a little raised sand-path with flattened, sloping sides wound away into a maze of shadows diapered with gold . . . behind the evergreen hedge she heard the liquid bubbling of a hidden water-fall, and when she had left the untempered sunshine behind her this murmur grew louder. It seemed as if the green gloom in which 



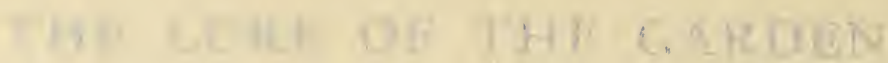

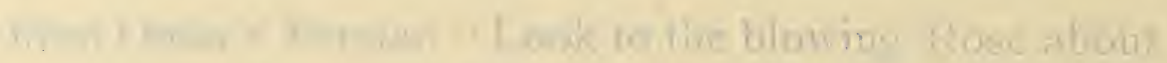

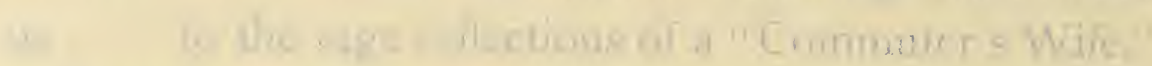

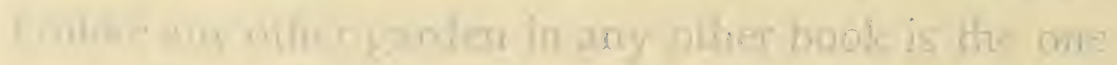

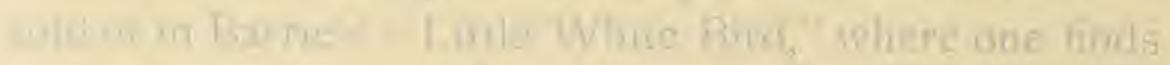

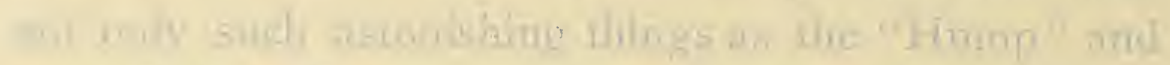

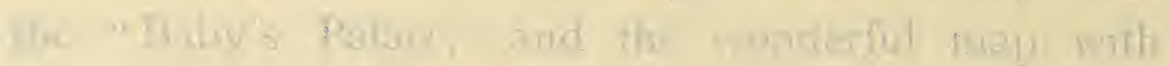

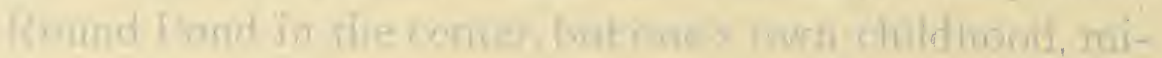

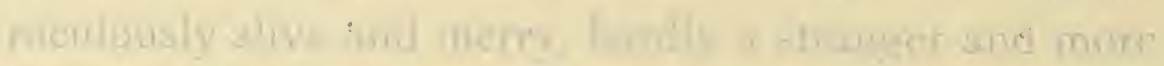

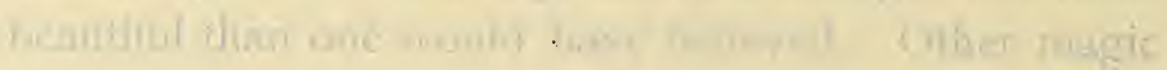

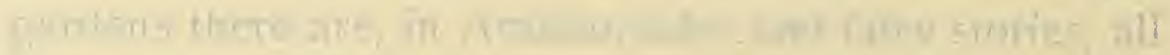

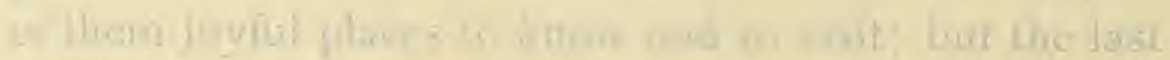

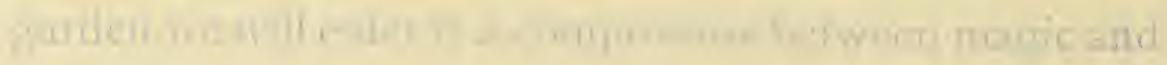

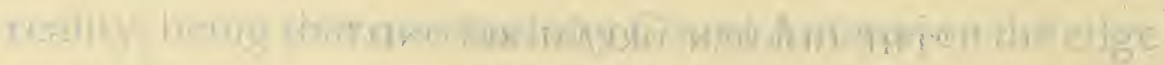

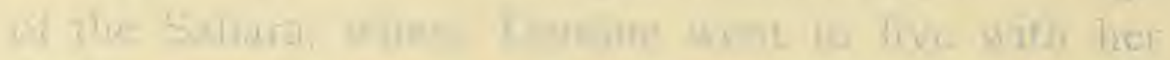

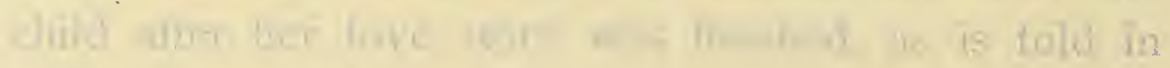
"the limenter of Mylit"

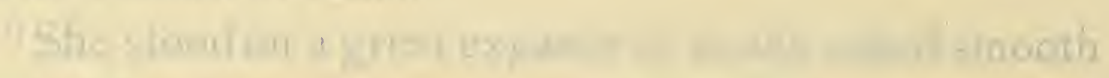

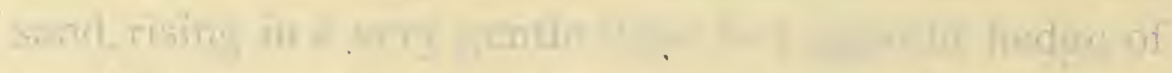

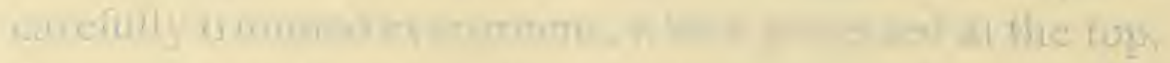

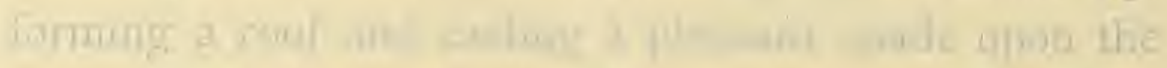

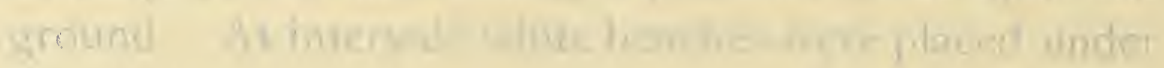

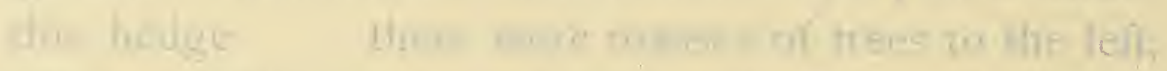

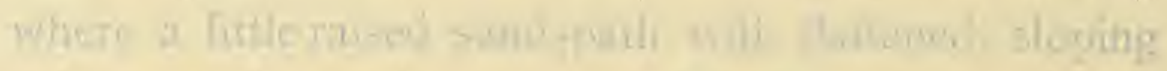

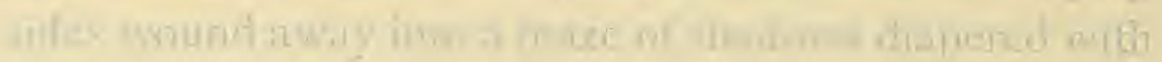

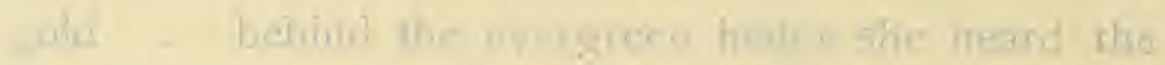

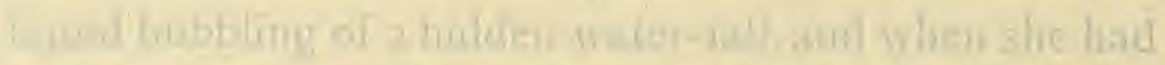

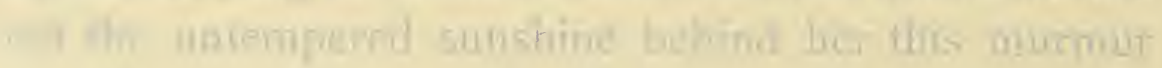

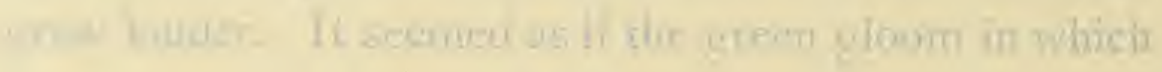
182 


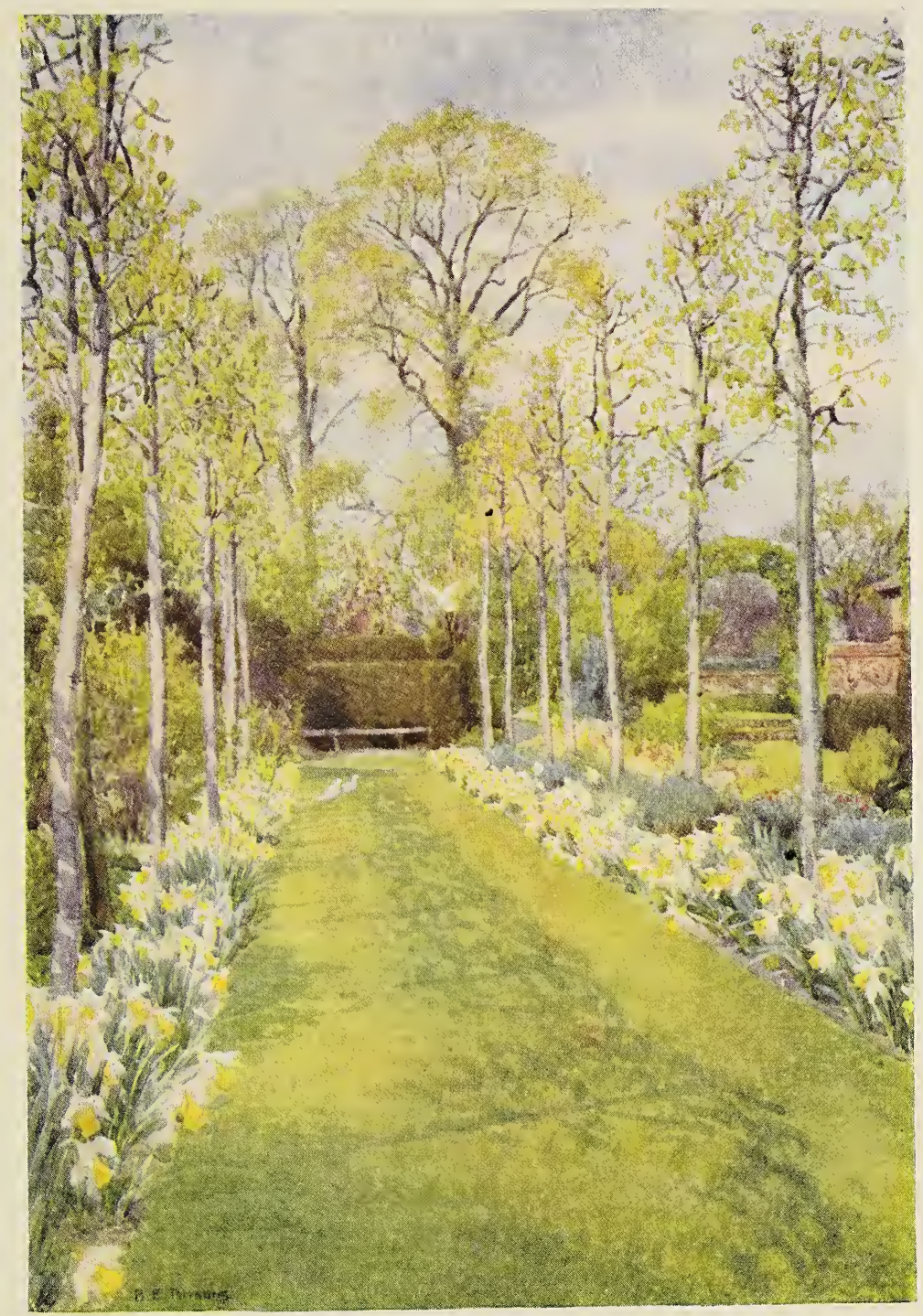





\section{GARDENS IN LITERATURE}

she walked acted as a sounding board to this delicious voice. The little path wound on and on between two running rills of water, which slipped incessantly away under the broad and yellow-tipped leaves of dwarf palms, making a music so faint that it was more like a remembered sound in the mind than one which slid upon the ear. On either hand towered a jungle of trees brought to this home in the desert from all parts of the world... thickets of scarlet geranium flamed in the twilight. The hybiscus lifted languidly its frail and rosy cup, and the red-gold oranges gleamed amid leaves that looked as if they had been polished by an attentive fairy. . . . Under the trees the sand was yellow, of a shade so voluptuously beautiful that she longed to touch it with her bare feet. . . Never before had she fully understood the enchantment of green . . . rough, furry green of geranium leaves, silver green of olives, black green of distant palms from which the sun held aloof, faded green of the eucalyptus, rich, emerald green of fan-shaped, sunlit palms, hot sultry green of bamboos, dull, drowsy green of mulberrytrees and brooding chestnuts. It was a choir of colours in one colour, like a choir of boys all with treble voices singing in the sun.

"Gold flickered everywhere, weaving patterns of enchantment, quivering, vital patterns of burning beauty. Down the narrow branching paths that led to inner mysteries the light ran in and out, peeping between the divided leaves of plants, gliding over the slippery edges

$$
\text { I } 85
$$




\section{THE , LURE OF THE GARDEN}

of the palm branches, trembling airily where the papyrus bent its antique head, dancing among the big blades of sturdy grass that sprouted in tufts here and there, resting languidly upon the glistening magnolias that were besieged by somnolent bees. All the greens and all the golds of Creation were surely met together in this profound retreat to prove the perfect harmony of earth with sun. . . The dream of this garden was quick with a vague and yet fierce stirring of realities. There was the murmuring of many small and distant voices, like the voices of innumerabletiny things following restless activities in a deep forest ... a brown butterfly flitted forward and vanished into the golden dream beyond. ..." 


\section{GARDEN GATES}


FROM

THE ROMAUNT OF THE ROSE (CHAUCER)

And whan I had a whyle goon, I saugh a Gardin right anoon, Ful long and brood, and everydel Enclos it was, and walled wel, With high walles embattailed . . .

Square was the wall, and high somdel; Enclosed, and y-barred wel, In stede of hegge, was that Gardin;

Com never shepherde therin. . . .

Tho gan I go a ful gret pas

Envyroning even in compas

The closing of the square wal, Til that I found a wiket smal So shet, that I ne mighte in goon, And other entree was ther noon ... Upon this dore I gan to smyte, That was so fetys and so lyte; Til that the dore of thilke entree A mayden curteys opened me. And forth, without wordes mo, In at the wiket went I tho. . . . 



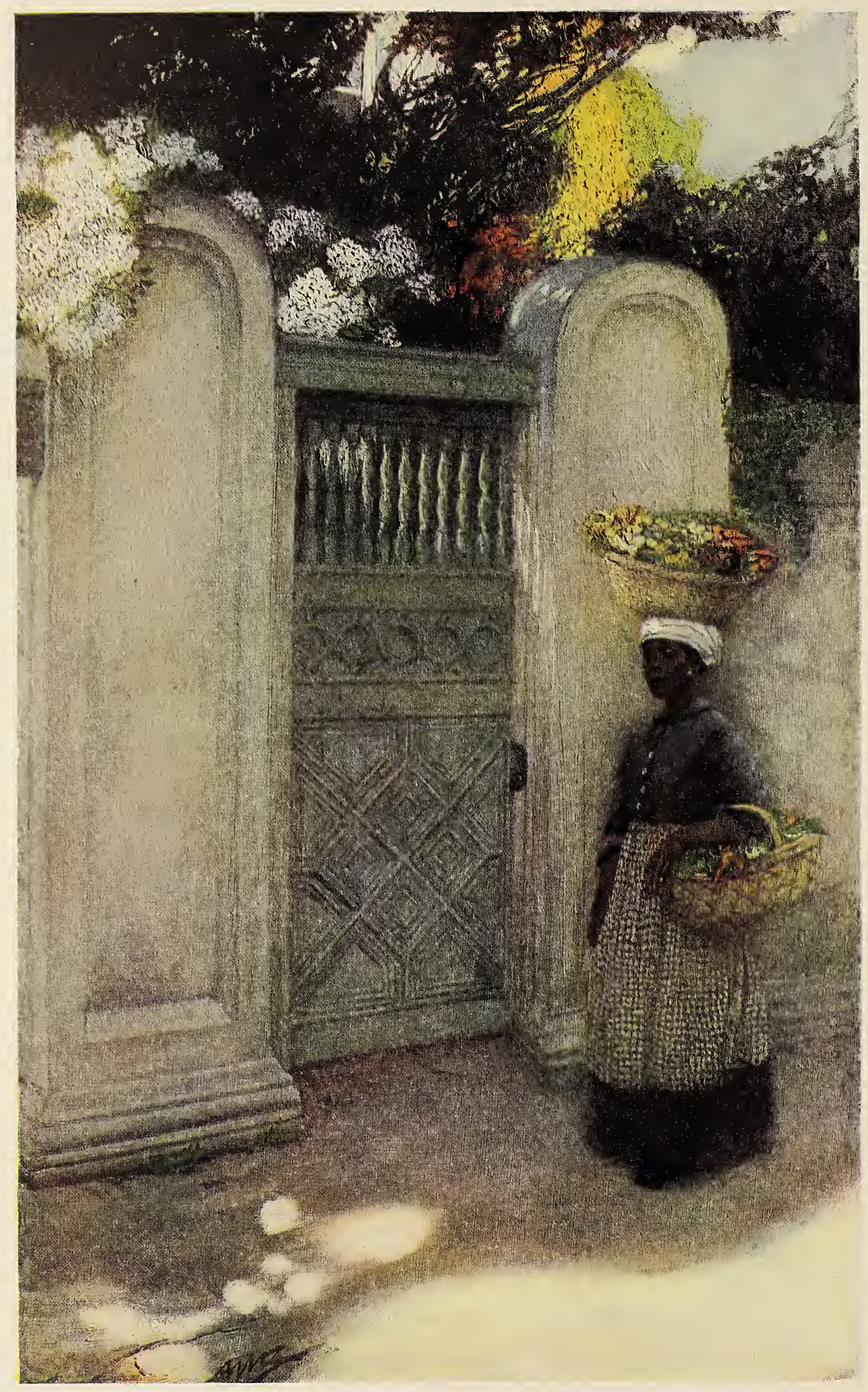




\section{CHATाTि $8 \mathrm{X}$ \\ GNRDEN GA7 HES}

TOHN WORLIDGE, writing lie 'h mat 7975

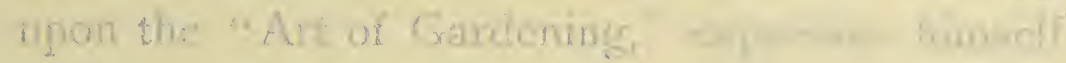
in this wise as negrats watk:--

"When you have diswoverel the Ir a I anil. doul

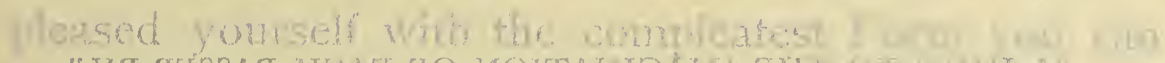

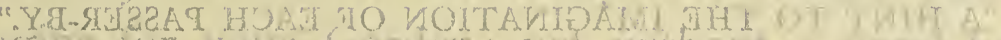

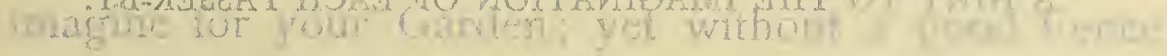
to preserve it from several evilts that wowilly athong is your labor is but lost."

He enes on to say that the Fience may is vinie or pariety of materials, but that of all the we. aif livitu

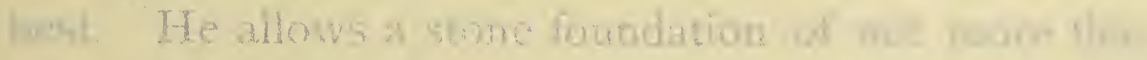

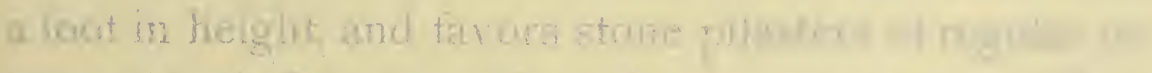

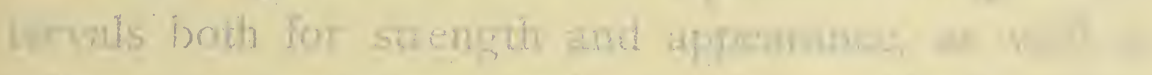

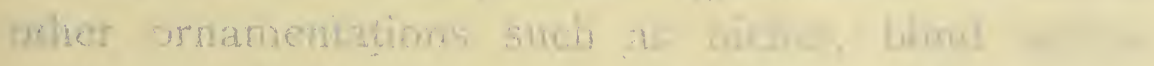

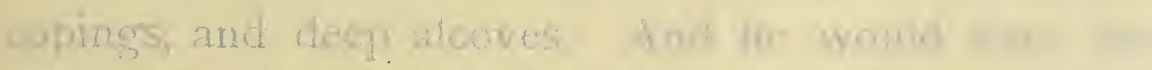

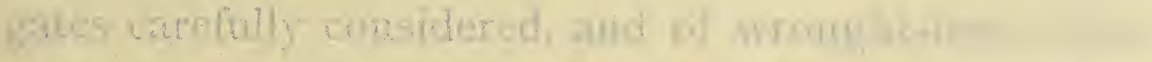

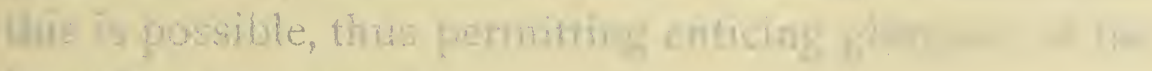
beauties they grard.

Many of Einglanil's inest places y sh | |

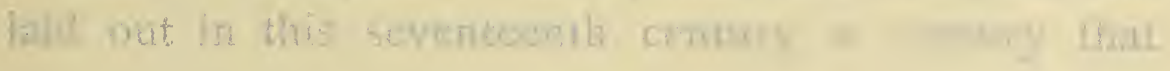





\section{Chapter IX}

\section{GARDEN GATES}

TOHN WORLIDGE, writing in the year 1675 upon the "Art of Gardening," expresses himself in this wise as regards walls:-

"When you have discovered the best Land, and pleased yourself with the compleatest Form you can imagine for your Garden; yet without a good Fence to preserve it from several evils that usually annoy it your labor is but lost."

He goes on to say that the Fence may be made of a variety of materials, but that of all the use of brick is best. He allows a stone foundation of not more than a foot in height, and favors stone pilasters at regular intervals both for strength and appearance, as well as other ornamentations such as niches, blind arches, copings, and deep alcoves. And he would have the gates carefully considered, and of wrought-iron where this is possible, thus permitting enticing glimpses of the beauties they guard.

Many of England's finest places were designed and laid out in this seventeenth century, a century that 


\section{THE LURE OF THE GARDEN}

gave birth to Inigo Jones and to Le Notre. Jones designed many of the splendid gates in wrought-iron that first came into use in the time of the Stuarts, besides the cottages and summer-houses, the pavilions and terraces with their flights of steps that remain a joy to this day. Le Notre's influence on English gardens of this period is marked, and it is supposed that he accepted Charles II's invitation to come to London, though there is no direct proof of this.

Such places as Hampton Court, Hatfield, Packwood, and Kew are full of fine examples of the best seventeenth-century taste. The famous flower-pot gates at Hampton Court make one of the most magnificent entrances to a great place that can be imagined. The high brick walls with their stone copings curve up to the immense sculptured stone pillars, surmounted by cupids holding carved baskets overflowing with fruit and flowers; between these are the great wooden doors studded with iron, and over the wall hang many varieties of vines, now completely hiding it, now revealing the pink bricks or gray-white pilasters. Another beautiful gate belonging to the same place is of wrought-iron in a design full of grace and strength, attained by a semi-circular flight of stone steps and hung between two brick pillars topped with stone balls. Even more perfect is Drayton, with its pleached alleys, its brick walls infinitely varied and yet harmonious, its grills and gates of wrought-iron, its niches, busts, 
. 


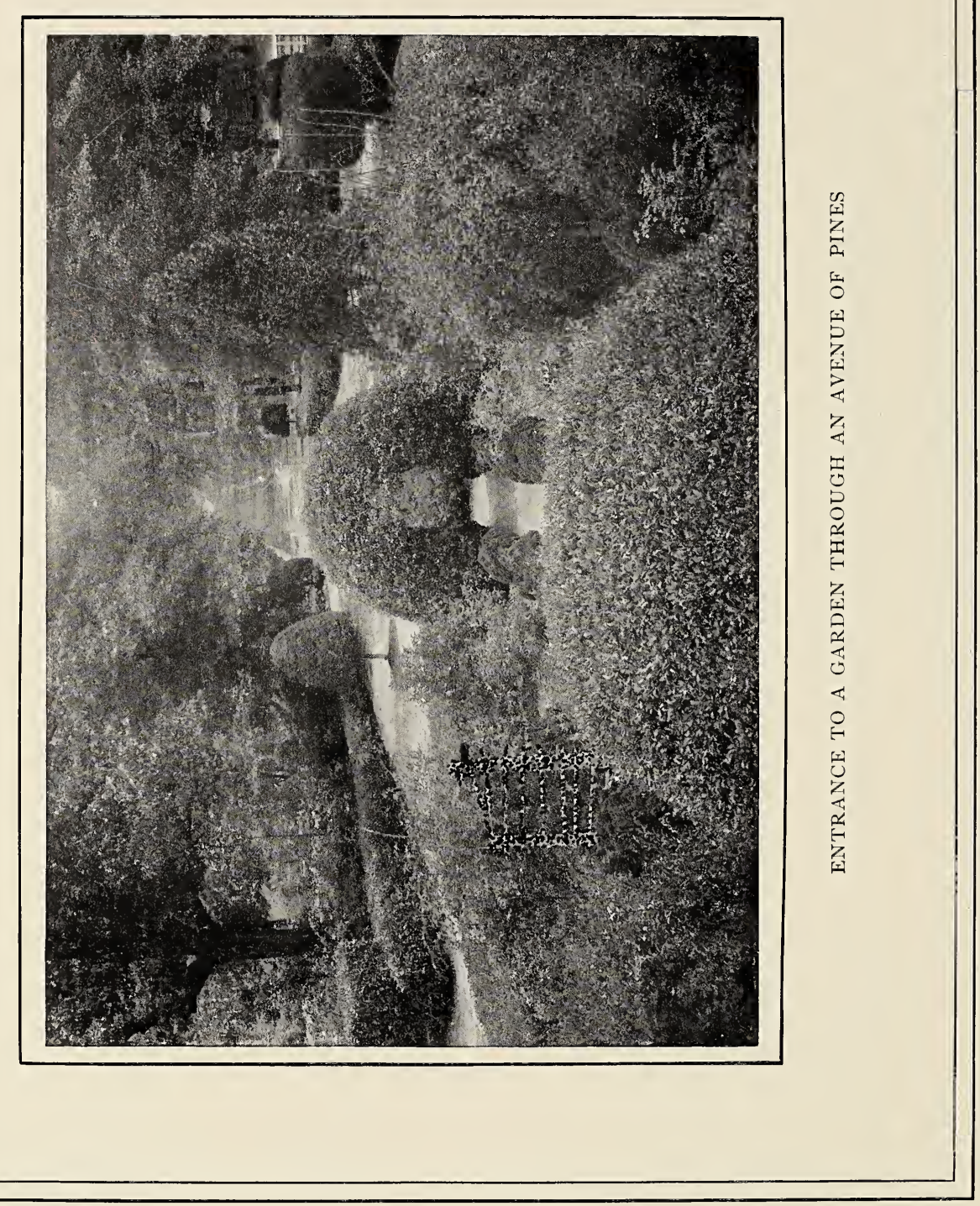




\section{GARDEN GATES}

and pilasters, its clipped trees rising above the copings in balls and obelisks, its amazing yew hedges fifty and sixty feet high, one behind another, arch behind arch, the arches topped by balls and points, with pediments over some.

Somewhat different is the wall and entrance at Montecute, in Somersetshire, stone being employed here as a solid foundation upon which is superimposed a very exquisite balustrade of marble. The gates are of heavy iron bars, very tall and severe, between huge stone posts topped by hollow circles. The vines, twining in and out of the columns, wreathe themselves in adorable festoons, and form a marvelous harmony of color with the ancient gray stone.

Brockenhurst, among many fine features, has a notable entrance. Behind a wrought-iron gate hung on brick pillars of noble shape, topped by marble urns, a wide path between clipped yews leads straight to a second gate whose sturdy pillars as well as the large balls that crown them, are completely covered by ivy. Four steps mount to this second entrance, and some ten feet beyond it a tall smooth hedge blocks further view. Against the somber darkness of this hedge, in a slight niche, is set a bust upon a slender column. Nothing more dignified nor more charming than this double entrance, with its hint of mystery, its color harmony of white and green and old brick, its straight lines and sense of space, can be thought of; it com- 


\section{THE LURE OF THE GARDEN}

pletely satisfies the demand for beauty, ${ }_{\text {i }}$ without revealing anything of the garden itself.

The variety of beauty attained both in England and Scotland by modifications of these brick and stone walls with wrought-iron gates is truly wonderful. Sometimes the family arms are sculptured on the pillars or the arch, or perhaps an ancient quotation or battle-cry. Sometimes a Gothic touch is given by strange animals that peer down upon the visitor, or by a gate-house whose architecture harmonizes with that of the main building. A French writer in the early years of the nineteenth century insists particularly upon this point, asserting that the chief entrance to the grounds should correspond to the house to which it belongs, should promise it, as it were. Let the gate to a princely place be princely, he says, immense and heavy, or springing into airy arches according as it is a castle or a palace to whose grounds you are being admitted; but to a simple cottage garden the gate should be simple too; a swinging lattice, a pierced door painted green, or a turnstile between white posts.

The English castles and abbeys built before the Stuart reigns possessed no such gardens as distinguish the later places. But they owned their closes and trim parterres, within their massive walls and behind great battlemented gate-houses, ivy-buried, turreted, and pierced by low arches. Dunster Castle, built under Henry II, has such an entrance, a fine building of 


\section{GARDEN GATES}

gray stone some forty-five feet in height, with four turrets and a broad arch between which hang the same doors of massive oak bound by iron bands and studded with spikes that have swung on their gigantic hinges since the castle was young. Above tower mighty trees, and the ivy hangs thick over the old pile; no better gateway to the grim barony could have been designed. So, too, at Warwick. There the way lies through a portcullised door and over a moat, the arch at once heavy and fine.

Beaulieu Abbey admits you through a lofty and beautiful archway closed by wooden doors of an unbelievable solidity, the whole built into the great gray wall that rises above clothed in its evergreen robe of clambering vine. The cloisters are a series of exquisite arches that give upon the garden within.

Then there is the Abbey of Battle, founded by William the Conqueror as a thanksgiving for some one of his victories. Here, too, the entrance is by a huge battlemented arch with sturdy turrets and a grim gate-house meant for defense as much as or more than for welcome.

In Italy, as in France and the British Isles, wroughtiron gates and high walls are the rule for the outer boundary. The Italian villas usually have several gardens, each with its particular and appropriate entrance. Thus the Villa Lanti has many a charming entrance within its main great gates. Some lead you 


\section{THE LURE OF THE GARDEN}

by gently sloping ramps between green hedges, under arches cut in the greenery and marked by obelisks of stone or huge jars of terra-cotta. Or perhaps you follow a curving flight of steps against a great stone wall that partly surrounds a fountain full of broken reflections, up to a terrace crowded with roses, stepping into a sudden glory of light and color from the cool shadow, with the sound of falling water in your ears.

The Villa Danti, with its magnificent view over the hills of Vallambrosa, is approached through lofty iron gates behind which are two carved stone flanges standing at either side of a long straight drive bordered by splendid cypresses, black against the sky. After passing through their stern shadow and slim formality, the garden, in its clipped and fantastic loveliness and the riot of its color, bursts deliciously on the view.

The Villa Palmieri has many gardens, each with its studied entrance. The coping of the high outer wall is finished in graceful curves, each rise topped with an urn. A massive entrance under a heavy arch makes the main gateway. Within are others manifold, some mere openings in the hedges marked by stone pines or a few steps, some proceeding through long pergolas floored with tiles and adorned by old busts and statues.

The Italians loved flights of steps that curved out of sight, and walls of varying heights, usually built of stone with niches for statues, and long seats. Fountains often fall down these walls. They loved long green alleys 


\section{GARDEN GATES}

too, and tall, slender pillars, cypresses, or pines to mark the gateway.

On the island of Corfu the Empress Elizabeth of Austria built a great palace where she spent much of her time. It has a wonderful outlook over the purple Grecian sea and tawny islands, and behind it lie the gardens, a floor higher than the front of the building. These are attained from within through the main hall of the palace, or from without by a flight of marble steps with a balustrade of beautifully carved pillars, at whose turnings stand statues. Beyond the topmost steps a serpentine path adorned by columns wreathed in creepers winds and winds until it achieves an airy colonnade from which the gardens drop away in three terraces. This colonnade extends on two sides, with statues at regular intervals before it, looking out into the garden; a formal garden of date- and sagopalms and flaming beds, ordered paths and rhythmic fountains, where marble steps and temples and statues play a great part, white against a myriad tones of green, for the vines have flourished everywhere.

In Spain the gardens are usually inclosed on three sides by the house to which they belong, while the open side has a wrought-iron fence with an arch or triple arch of stucco surmounted by small cupolas for the entrance; such, for instance, as obtain in the garden of the Alcazar at Seville. In Mexico we see the same characteristics; while often the only entrance is through the house, as in the old Borda gardens. Here 


\section{THE LURE OF THE GARDEN}

the plain, rather desolate hall opens on a colonnade in whose graceful arches hang baskets of flowers alternating with bird-cages where brilliant parrakeets or singing-birds disport themselves, according to the way of birds. A mass of roses blooms beyond, through which a red-tiled broad path descends by slow degrees toward the main portion of the garden, thickly bowered in trees and ending in an artificial lake of great beauty. This kind of entrance makes a sort of frame through which the garden gleams and shimmers, and is very effective; but it is only possible where it is private, where the garden is more of an inner court appertaining to the house and not exposed to the public gaze. Gardens like this are common in Persia, the flower-planted space, the pool, the tesselated pavements and alleys of slender trees all visible from the house through high arches on slim columns, but entirely guarded from outside view by the building itself or a high, forbidding wall. In India, too, the wall and gate are usually designed with the idea of entirely hiding the garden behind. The wall is commonly pierced with a high, beautifully decorated arch, and closely shut with thick wooden doors; these might open into a desert for all the hint of green growth they permit of escaping.

The Japanese fashion is utterly different, however. Here the garden is meant to be looked at; it is a glory to be shared with a world that loves it, and which, passing by happily, looks but never intrudes, experiencing 


\section{GARDEN GATES}

simply a hushed joy over the quaint and careful beauty. The walls therefor are low, the gates of wattled bamboo or interlaced wood, bold in form, hung between high, straight poles and topped by transverse beams inclining upward at the ends. Old stone or bronze lanterns sometimes mark these gates, and bright-flowering trees are planted beside them. Often the entrance is over a bridge, and at times the garden is on a slight hill with flights of steps, spanned occasionally by arches, leading up to it. Now and then pagodas are built at the entrance to a large garden, or the gate takes the form of a thatched cottage, or is oddly carved, fantastic, or brilliantly lacquered.

In America there is still much to do as regards both wall and gate. One charming development of the wooden fence occasionally met with, is the shingled wall left to weather, with a latticed gate between higher posts topped by balls or short spires and left gray or painted red or white or green, according to the prevailing color of the house. A fence of this sort is a complete protection from alien observation, while the gate allows just the glimpse that gives so pretty a bit of information regarding the hidden Eden, demurring delightfully against any accusation of selfishness which might be hurled at the wall. Vines grow well on these shingled fences, and the top can be treated in a variety of ways, all good.

Several New England gardens have very high, wattled fences that are simple and picturesque and form an excellent support for every kind of creeper. Wooden 


\section{THE LURE OF THE GARDEN}

gates are the best in these, and are especially lovely under light arches twined with rose or honeysuckle, or opening into arbors. A pretty gateway of this sort in an old Long Island town has a double-trellised arch overgrown with clematis, with a low, white-and-green gate and two seats just inside. Three stone steps lead up beyond these seats to a box-bordered path.

A garden gate is different from a house door, and though opposing itself to undesired intrusion, it should nevertheless allow something of what it guards to be seen; a flash of color, a curving pathway, a vista of well-planted trees or sweep of lawn; a hint to the imagination of each passer-by, in fact, a gift of beauty. For since nature is largely responsible for a garden, a little of the generosity of her rains and sunlight and secret forces should emanate from every true garden. And where more aptly than through the gate, built as it is to let the favored into all the cherished mysteries, should this gift come? Build your walls to keep the world away, to insure you peace and seclusion. But let your gates mitigate this necessary severity. Make them beautiful as well as appropriate; and whether they are princely or humble, be content to allow some of your garden's loveliness to escape through them to augment the general delight in what is lovely;-if it be no more than two pots of geranium or begonia set upon the posts, as is the fashion in some French villages, or a flowering shrub in the archway. 


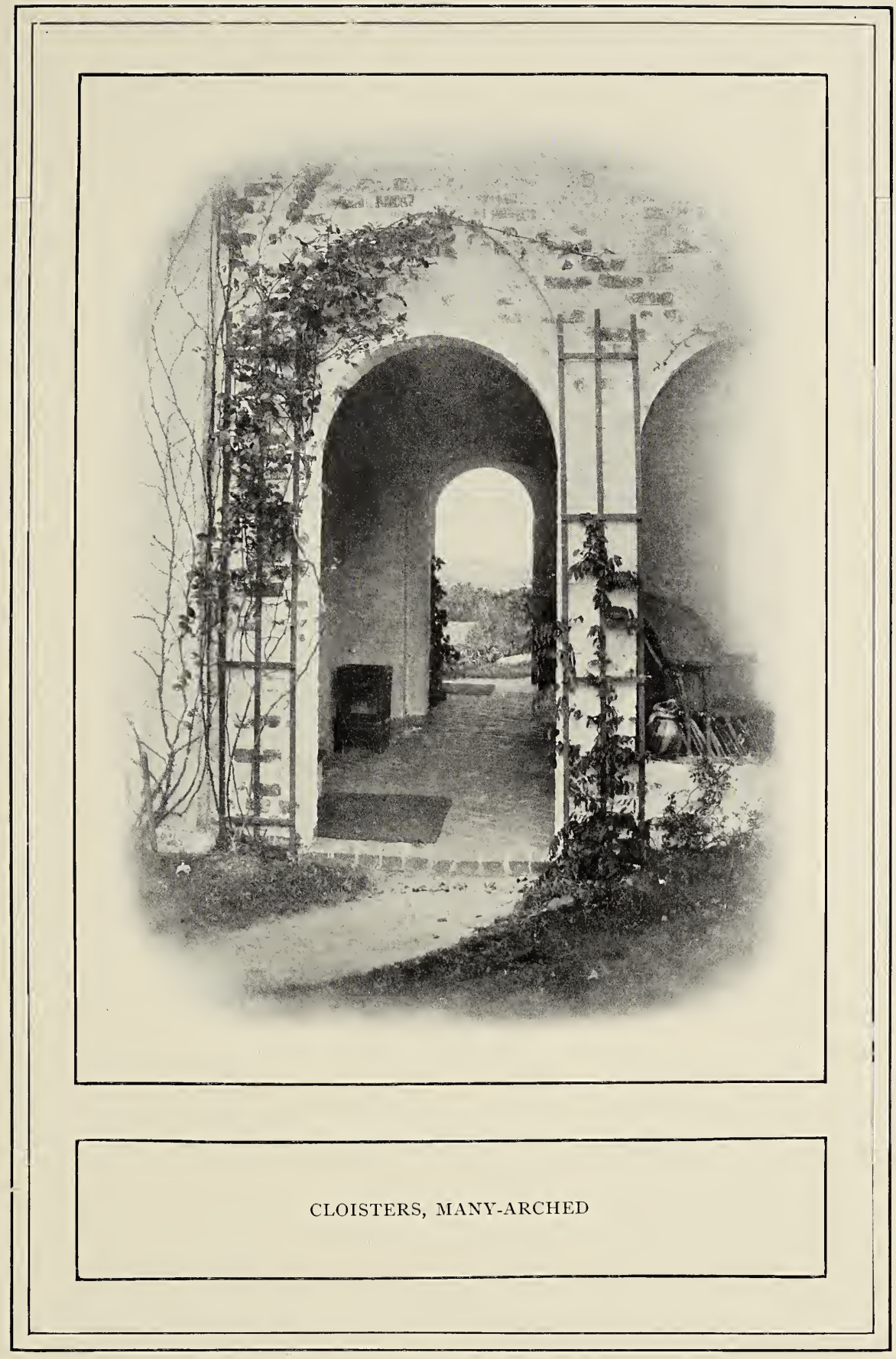





\section{GARDEN GATES}

Think that the first impression is given by your gate. It is both a warning and a promise, an index to your taste, a revelation of character. At once yielding and withholding, it stands between you and the outer world, obedient to your desires. You should treat it with consideration, sparing no pains to make it fit and fine. 

GARDENS PUBLIC AND BOTANICAL 


\section{KEW GARDENS}

\section{ANONYMOUS}

So sits, enthroned in vegetable pride, Imperial Kew, by Thames's glittering side :

Obedient sails from realms unfurrowed bring For her the unnamed progeny of Spring.

Delighted Thames through tropic umbrage glides, And, flowers Antarctic bending o'er his tides, Drinks the new tints, the sweets unknown inhales, And calls the sons of science to his vales. In one bright point admiring Nature eyes The fruits and foliage of discordant skies, Twines the gay flow'ret with the fragrant bough, And binds the wreath round George's regal brow.

Sometimes, retiring from the public weal, One tranquil hour the Royal Partners steal, Through glades exotic pass with step sublime, Or mark the growth of Britain's happier clime. 


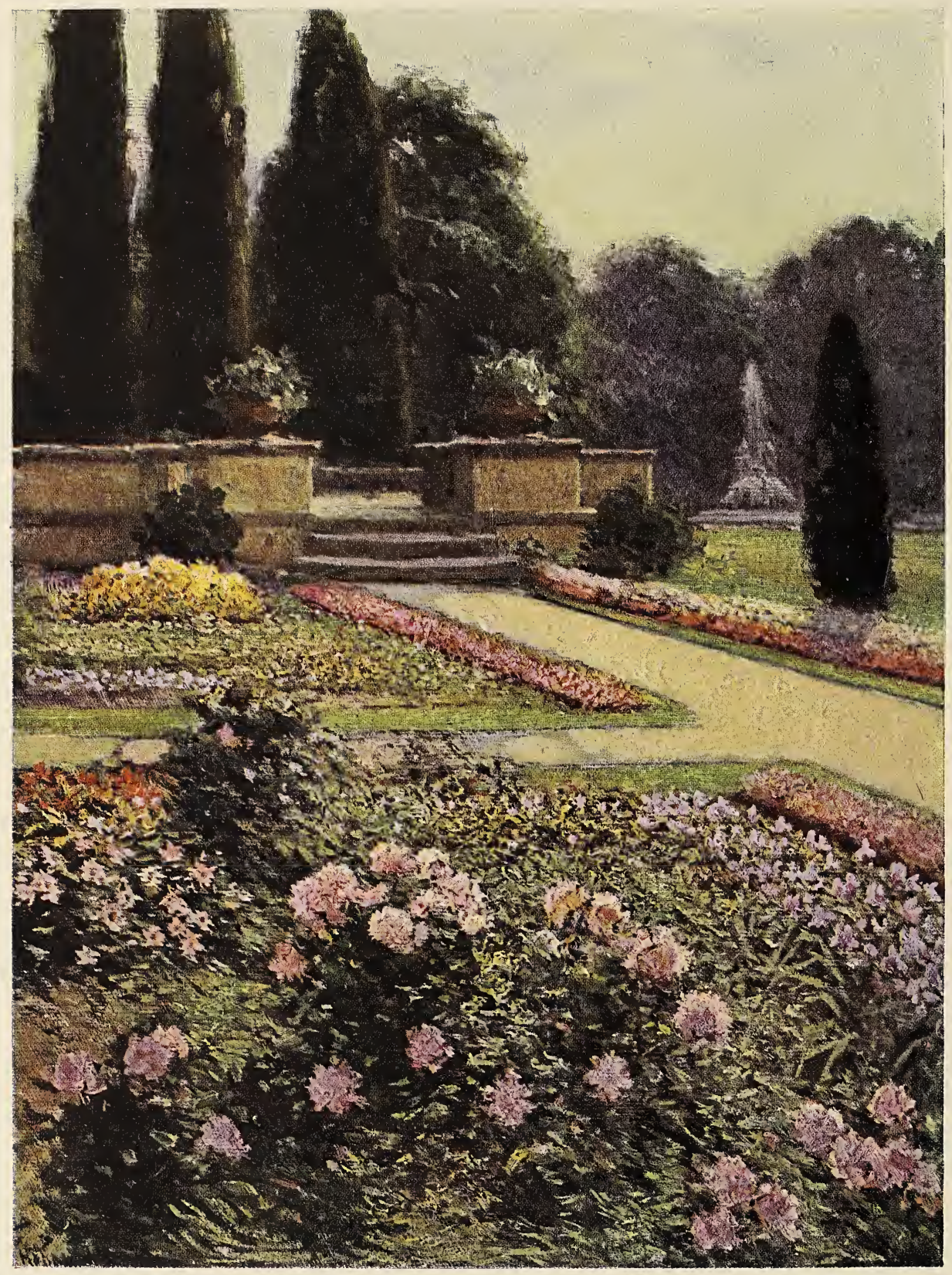




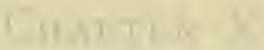

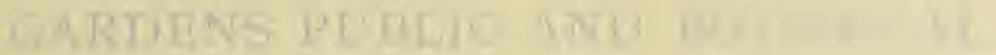

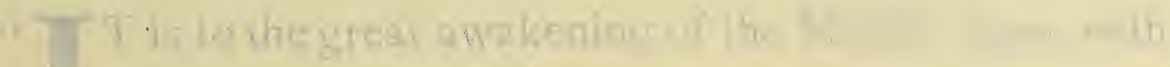

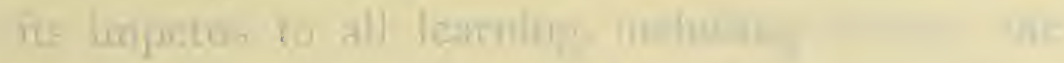

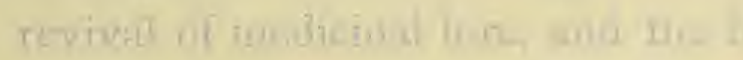

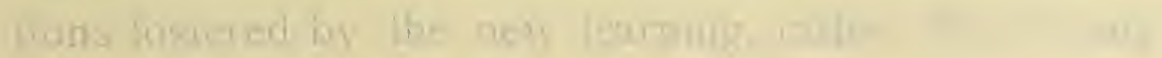

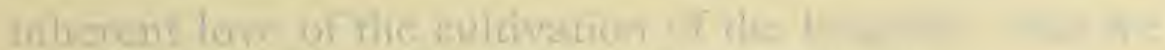

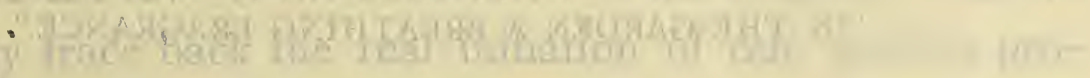
fictency in the arv od sarteming

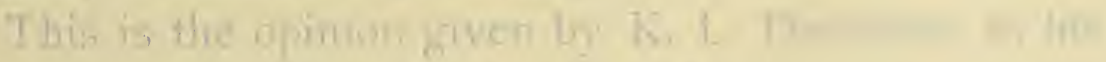

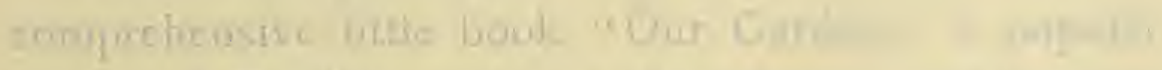

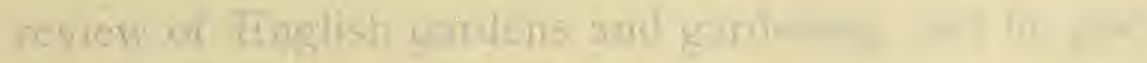

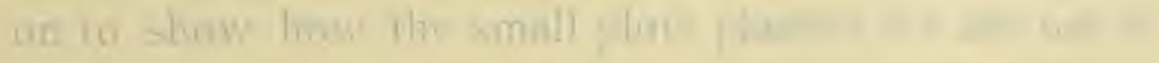

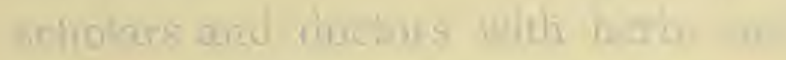

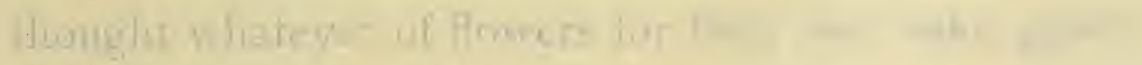

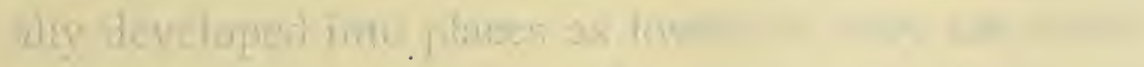

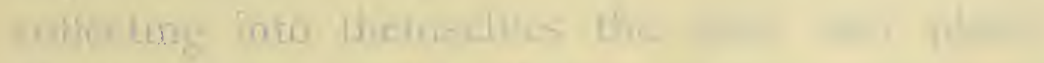

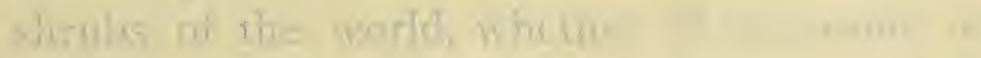
salise, no extectimenting siln พ.เ

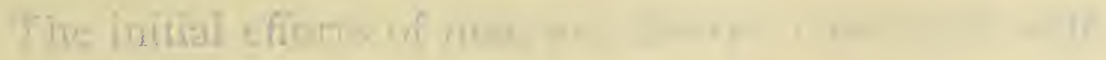

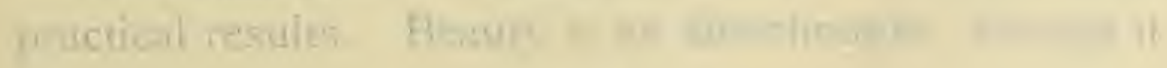





\section{Chapter $\mathrm{X}$}

\section{GARDENS PUBLIC AND BOTANICAL}

I

$\mathrm{T}$ is to the great awakening of the Middle Ages, with its impetus to all learning, including botany, the revival of medicinal lore, and the botanical collections fostered by the new learning, rather than to any inherent love of the cultivation of the beautiful, that we may trace back the real initiation of our modern proficiency in the art of gardening."

This is the opinion given by K. L. Davidson, in his comprehensive little book, "Our Gardens," a popular review of English gardens and gardening, and he goes on to show how the small plots planted for the use of scholars and doctors with herbs and simples, with no thought whatever of flowers for their own sake, gradually developed into places as lovely as they are useful, collecting into themselves the trees and plants and shrubs of the world, whether of economic or esthetic value, and experimenting along many lines of use and beauty.

The initial efforts of man are always concerned with practical results. Beauty is an afterthought, though it 


\section{THE LURE OF THE GARDEN}

may become a preponderating one; and it is interesting to look back through the centuries upon these elementary plantations that time has caused to blossom so wonderfully, these beds of "weeds" that have turned to lilies and roses.

The earliest public "physick gardens" are discoverable during the sixteenth century in various parts of Europe, the first being that established at Padua in I545, for the benefit of students at the university. Others soon followed in different Italian and French towns, all devoted to the cultivation of plants thought to be potent either as medicine or poison.

English scholars of that time complained bitterly that they were forced to travel so far to study even the elements of botany; for it was not until close upon a hundred years later that the first English public physic garden was made possible, by the gift, in 1632 , from the Earl of Danby, of a tract of land to the University of Oxford. This prospective garden contained some five acres, much of it low and marshy, lying between the water walks of Magdalene College and Christ Church, close to the bridge over the Clerkwell. It was even then historic ground, being the site of an ancient Jewish burial-ground, and it had long lain neglected.

Scholars and noblemen interested themselves in this garden, much labor was expended upon it, and it received many donations of plants and specimens, as well as valuable volumes for its library. It soon be- 


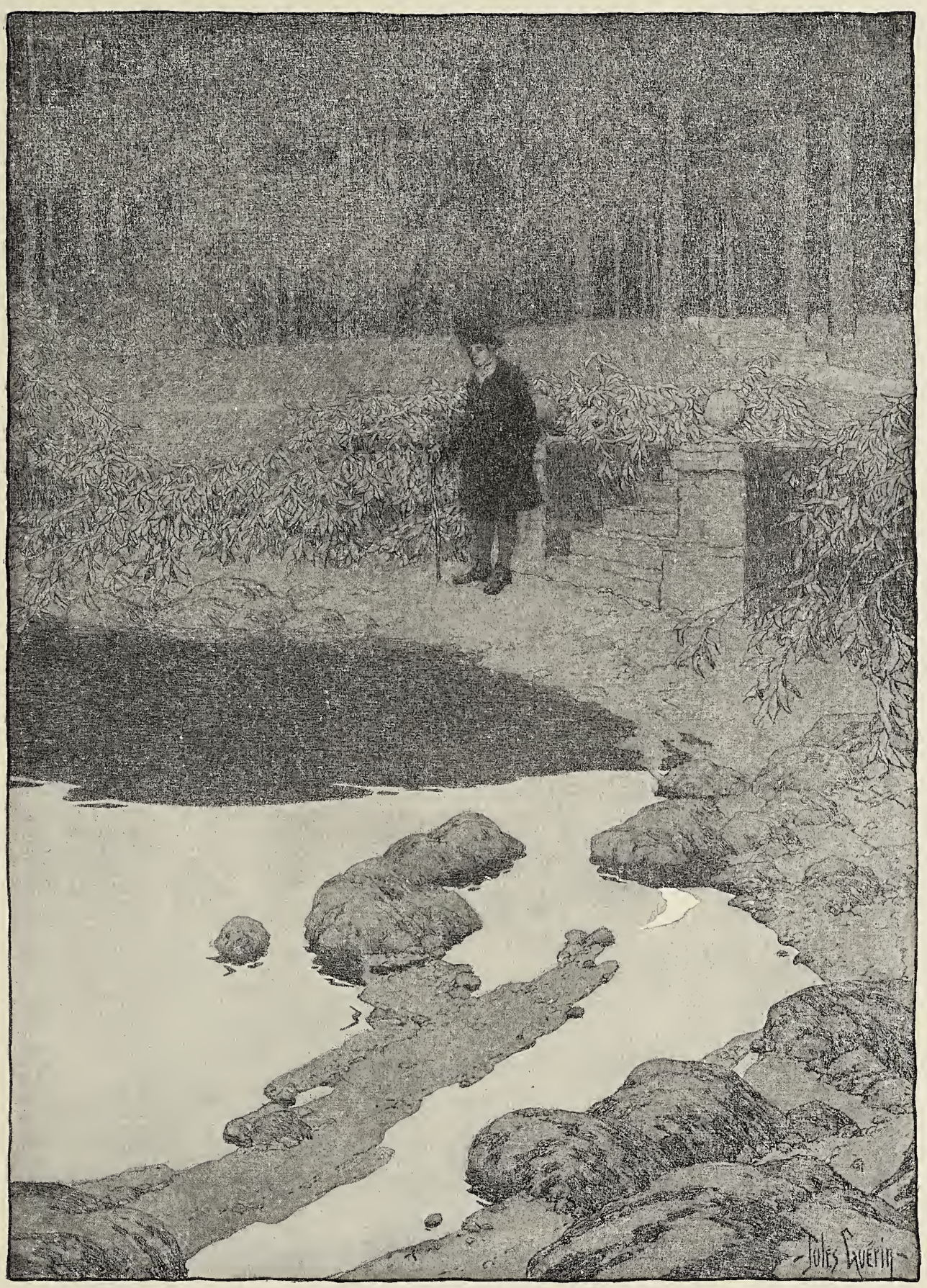

POOLS AND SILENCES 



\section{GARDENS PUBLIC AND BOTANICAL}

came renowned, and was visited by botanists from distant parts, among them the Swede Linnæus, then at the beginning of his fame.

The place remains, to this day, little altered. The time-honored yews, once clipped into the shape of guardian giants, still watch at the gate. Many a plant brought ages since from alien climes has become acclimated, and gradually wandered from the borders to find congenial support in the crevices of the old walls, or, farther still, abroad in the country. Such has been the way of the Oxford ragwort, now common in the neighborhood.

It is a subject of congratulation, says Mr. Davidson, that "the first English physic garden has been permitted to remain with all its old-world associations so far unobliterated." A green and fragrant spot, it continues to abide within the shelter of the university, seemingly quite as immortal as the gray and ivy-hung walls of the buildings that surround it.

There were, nevertheless, at least two private physic gardens before this one at Oxford. The first dates back to before I596, when John Gerarde, "the father of English herbalism," published his famous "Herball " and catalogue of the plants in the garden adjoining his house in Holborn. There is an amusing story told of a certain Thomas Johnson, who brought out an "Herball" of his own, in which he derided Gerarde's work, and proclaimed interesting discoveries made by himself, 


\section{THE LURE OF THE GARDEN}

among them the finding of a rare "peionie" growing wild in Kent. This discovery aroused considerable excitement, until it was proved that the too-zealous botanist had himself planted what later he was to discover.

Of a different stamp from Johnson was Tradescant, who brought out a revised edition of Gerarde's "Herball" and who made what seems to have been the second private physic garden known to England in the year 1630. He was a man of fine mind and intense application. His collection of natural history specimens went to Oxford after his death. As for the garden, that was continued for a while by his son, but in I749, Sir William Watson notes that it had fallen to ruin.

Following these came the famous Chelsea Gardens, which share with that of Oxford the distinction of being maintained to this day. These gardens were made by the Society of Apothecaries, but just when they took form is not known. The first official mention of them in the minutes of the society is in 1774 , when certain members proposed building a wall about them at their own expense. They had, however, been in existence long before this. Evelyn notes the fact of a "Botanick Garden" in Westminster as early as 1658 , and twenty years later this garden. was leased by the society, probably as an addition to their own. And in I69I, there is a description by the president of the 


\section{GARDENS PUBLIC AND BOTANICAL}

society to this effect: "Chelsea Physick Garden has great variety of plants both in and out of greenhouses: their perennial green hedges, and rows of different coloured herbs are very pretty; so are the banks set with shades of herbs in Irish stitch-way."

In I820, Henry Field, a member of the society, published a delightful account of them. They continue in excellent condition, and are the only gardens belonging to a society that have been kept up for so long a space of time.

The finest botanical gardens in the world are those at Kew. Their history is not uninteresting. They first come into notice about the middle of the seventeenth century as the property of a Mr. Bennett, whose daughter married a Lord Capet, taking the estates with her. Later on, the astronomer Molyneux married Elizabeth Capet, and the place passed to him. He was secretary to the Prince of Wales, later George II, whose son, Frederick, father of George III, took a great fancy to Kew, finally leasing it from the Capet family for a long period. He immediately began to improve the grounds, which contained some two hundred and seventy acres of a charmingly diversified character. After his death his widow, Princess Augusta, continued this work with enthusiasm, commissioning Sir William Chambers to build temples, summerhouses, and gates that still delight the eye. She also commenced the exotic department, to which donations 


\section{THE LURE OF THE GARDEN}

were made by many persons, chief among them that Duke of Argyle called the "Tree-monger" by Horace Walpole on account of his passion for fine trees. He sent the queen a large number of rare and foreign trees for the gardens.

In I759, Aiton, a pupil of the celebrated Philip Miller of Chelsea Gardens, was made director. "A gentleman," says an old record, " no less distinguished for his private virtues than his knowledge of plants, and great skill in cultivating them." What he did with his private virtues we are not informed, but his professional abilities "quickly secured him the notice of the late Sir Joseph Banks, and a friendship commenced which subsisted between them for life."

It was this same Sir Joseph who made a voyage round the world, and sent many valuable plants and seeds to Kew.

George III finally purchased the estate, continuing to improve it. He tore down Kew House, and removed its furniture to a quaint red brick mansion of a far older date, which had once been owned by a Sir Hugh Portman, "the rich gentleman who was knighted by Queen Elizabeth." This house was afterward known as Kew Palace, and it was here that Queen Charlotte died. Kew now became the favorite royal suburban residence, and daily grew more beautiful.

It remained a possession of the crown's, being maintained by funds supplied by "The Board of Green 



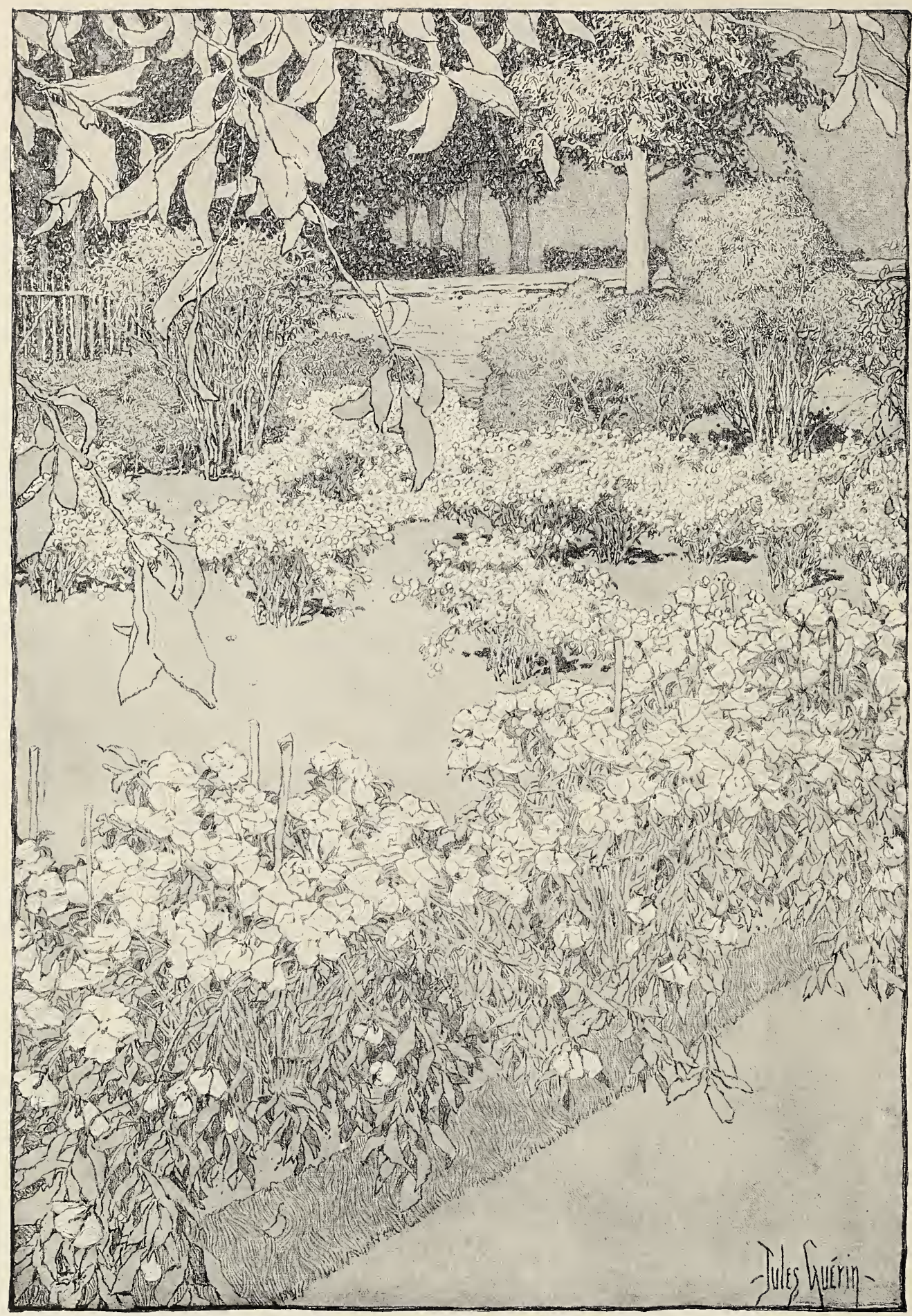

WHERE THE SHRUBBERY REACHES HIGH 


\section{GARDENS PUBLIG AND BOTANIGAL}

Cloth," until Queen Victoria relinquished it, "for the common good," making it public property. It has since then become the resort for thousands upon thousands of visitors, and a delight to lovers of beauty, besides being of the utmost value to botanists, agriculturists, and experimentalists.

Sir William J. Hooker, director for many years, published the first Guide to the gardens, a little volume as interesting as it was useful, decorated with funny little woodcuts, and prefaced by a page or two of Rules and Regulations sufficiently amusing.

"No person attired other than respectably can be admitted.

"It might scarcely be thought needful to say, that all play, leaping over the beds, and running are prohibited. Yet they have been practised, and so heedlessly that very serious injuries have resulted from falls, and grievously scarred faces have been the memento of such folly.

"It is requested that visitors abstain from touching plants and flowers; a contrary practice can only lead to the suspicion, perhaps unfounded, that their object is to abstract a flower or a cutting, which, when detected, must be followed by disgraceful expulsion."

He concludes that much more might be said on these heads; but asserts that the director "while bearing willing testimony to the excellent conduct of the many thousands who visit the Gardens, prefers to rely on the 


\section{THE LURE OF THE GARDEN}

good sense and honourable feelings of the visitors . . . rather than to multiply restrictions which may not be absolutely required." His expression may be a bit foggy, but the underlying idea is certainly very British and sporting.

Not only do Kew Gardens present the most exquisite landscape effects, and bring within their compass the plant life of the entire globe, either in the gigantic greenhouses and orangeries, or else in bed and border, on hill-slope and valley bottom, or along the banks of "delighted Thames," but they are of inestimable benefit in testing the best methods of cultivation, in studying the various food and drink plants, the medicinal herbs, and the countless trees and plants of economic value. Here the good is separated from the bad, the haphazard reduced to rule of thumb, the diseases of plant life treated, and all the intricacies of fertilization, cutting, slipping, and hebridizing closely studied.

Moreover, here you may see the various forms of formal and wild gardening, the treatment of drives, the planting of banks, the grouping of trees, and making of lawns. Landscape gardening, massing of color, the possibilities of winter planting, all receive due attention, each season showing at its best and bravest. The best topiary work, the use of the pleached alley, the trimming of hedges; what may not be learned in these wonderful gardens? 


\section{GARDENS PUBLIC AND BOTANICAL}

There is an interesting link between the Botanical Garden of Missouri and Kew. This magnificent western garden was the gift of Henry Shaw, an Englishman from Sheffield, son of a cutler and iron-worker who came to America to push his fortunes. The boy soon started out on his own account, with a small stock of merchandise, and after visiting various cities, finally settled in St. Louis, then, I819, no more than a small French trading-post. Here he prospered exceedingly, and in twenty years had made a fortune equivalent to a million nowadays. Upon this he retired.

A cool-headed, cool-hearted man, with neither wife nor intimate friend, he spent some time traveling about Europe and England. Finally, at Chatsworth, where Mary, Queen of Scots, was for so long a prisoner, the beautiful gardens inspired him with the desire of himself creating a garden. He returned to St. Louis, and spent the remainder of his life and the greater part of his fortune in the delightful labor. He soon got into communication with Sir W. J. Hooker, of Kew, and received from him the most enthusiastic assistance and advice; for Hooker not only greatly improved his own charge, but was constantly on the alert to do whatever lay in his power for others, and this garden enterprise in the New World touched him closely.

Shaw left the gardens to the State on his death, and they have been carried on with the best results of beauty and of scientific use. 


\section{THE LURE OF THE GARDEN}

One of the most beautiful public gardens in the world is that at Wisley, belonging to the Royal Horticultural Society. It was first laid out by a Mr. Wilson, who purchased a hillside farm, Oakwood, for the purpose of making a wild garden on a scope hitherto unimagined. By degrees he converted the sixty acres of his holding into a perfect wonderland of bloom. Rare flowering shrubs and trees from all over the world grew at their ease among the native woods; along the watercourses the finest Oriental irises mingled their splendor with simple English blossoms, and on the rocky slopes, Alpine flowers crowded joyously. Rhododendrons from the Himalayas and azaleas and cherries from Japan were equally at home, while water-plants, bulbs, perennials, and climbers appeared to follow everywhere their own sweet will.

After Wilson's death, Sir Thomas Hanbury bought this lovely place and presented it to the society, then at its wits' end to find suitable grounds to replace those in its possession at Chiswick, which the growing encroachment of London was wiping out of existence. Of course, some changes had to be made to fit the garden for the uses of the society, but these were not radical, and the place remains uniquely charming.

There are many botanical gardens in the tropics, chief among them, probably, being those situated at Peradeniya, in the center of Ceylon. These gardens are beautifully laid out, and are largely employed in 


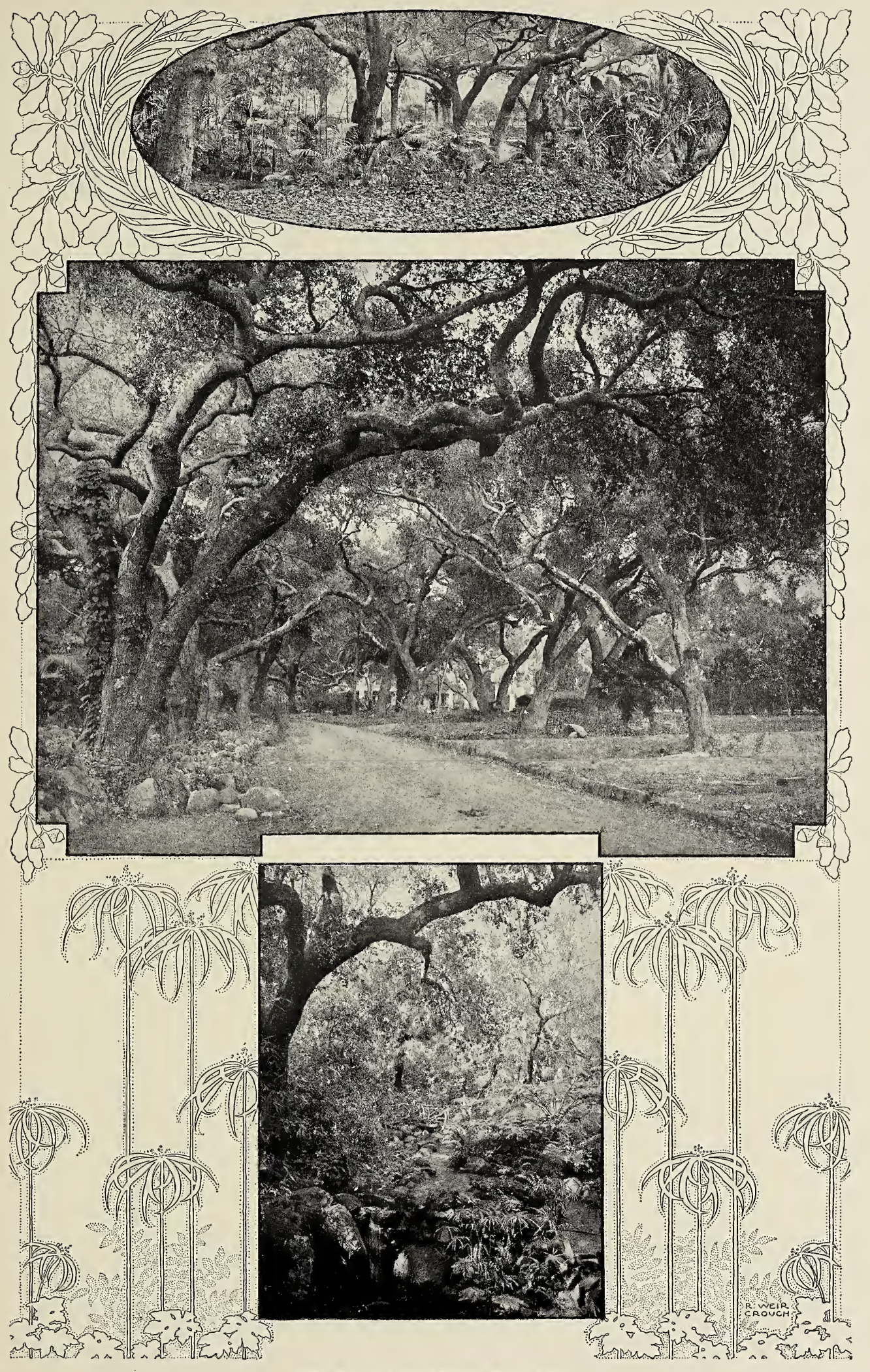

THE ENCHANTMENT OF GREEN 



\section{GARDENS PUBLIC AND BOTANICAL}

cultivating the many tropical trees and shrubs of economic value, the spices, teas, coffees, and chocolates, the various valuable palms, the giant bamboos, the gamboge, and indigo, and the hardwood trees. The gardens vary considerably in soil and temperature, lying partly on the hills and partly in low, marshy ground, and are capable of producing an amazing variety of plants. The philosopher Haeckel, who spent four days in them, asserted that four months of hard work at home would not have given him the same results.

On the decorative side, tropical gardens are chiefly confined to blossoming trees, for though there are some splendid lilies and creepers, there are practically few bedding flowers. But the trees are marvelous! There is the flame-tree, the different mimosas, an Indian tree that in its season is a solid mass of orangecolored flowers, and all the genus of Brownea, whose new terminal leaves are scarlet or rose, and hang pendant at the ends of every twig, presenting the least possible surface to the heat of the sun while too young to stand his full fervor. Then the hundreds of varieties of palms and palmettos and the so-called pines, the oranges and lemons wrapped in fragrance, the poincianas. A real glory of color and rank growth.

An unexpected and altogether delightful garden is the public one at Venice, which was made by Napoleon, who pulled down a number of ancient palaces and churches to get the necessary space. His 


\section{THE LURE OF THE GARDEN}

stepson, Eugène de Beauharnais, carried out the emperor's plans when affairs of moment called the latter away. These gardens stretch along the water's edge in half-tropic loveliness, the paths shaded by lindens, mimosas, orange- and lemon- and magnolia-trees, with palms and palmettos boldly placed. There is a charming garden café with music every afternoon, there are formal flower beds and green grass, and, though small, the place is very effective. But the flower spot of Venice is the Eden Garden, where each morning the boats come to the water-gate for their day's supply to be sold in the piazzas and calles. The flowers are unbelievable; solid squares of bloom, sheets of color. Surely such a mass of flowers was never collected in so small a space elsewhere on earth. The roses, hanging curtains, loads under which the bushes fairly stagger, or standards cut back to bring a single marvelous blossom to perfection. The perfume from the lily beds makes the head swim, and the carnations crowd together drunk with their own loveliness.

There is many another public garden that might be mentioned. The beautiful ones in Paris and at Versailles; those in Berlin and Dresden, and many here in our own country, though we have not yet attained the perfection of those abroad, being naturally many years behind the oldest and the finest. But these are enough to show how deep is our debt to the early "physick garden" of the Middle Ages, with its small collections 


\section{GARDENS PUBLIC AND BOTANICAL}

of plants pored over by dusty scholars, its beds in the "Irish stitch-way," and its entire lack of interest in the flower for the flower's sake. The fact remains that not one of us who plants a bulb or a cutting but owes these ancient botanists thanks, and can spend a pleasant hour or so perusing the quaint old herbals and catalogues which remain as witness of their labor. 

WINTER WONDER 


\title{
THE SNOW-STORM
}

\author{
BY RALPH WALDO EMERSON
}

Announced by all the trumpets of the sky, Arrives the snow; and, driving o'er the fields, Seems nowhere to alight; the whited air Hides hills and woods, the river, and the heaven, And veils the farm-house at the garden's end.

Come see the north-wind's masonry!

Out of an unseen quarry, evermore

Furnished with tile, the fierce artificer"

Curves his white bastions with projected roof

Round every windward stake or tree or door;

Speeding, the myriad-handed, his wild work

So fanciful, so savage; naught cares he

For number or proportion. Mockingly,

On coop or kennel he hangs Parian wreaths;

A swan-like form invests the hidden thorn;

And when his hours are numbered, and the world Is all his own, retiring as he were not,

Leaves, when the sun appears, astonished Art

To mimic in slow structures, stone by stone,

Built in an age, the mad wind's night-work,

The frolic architecture of the snow. 


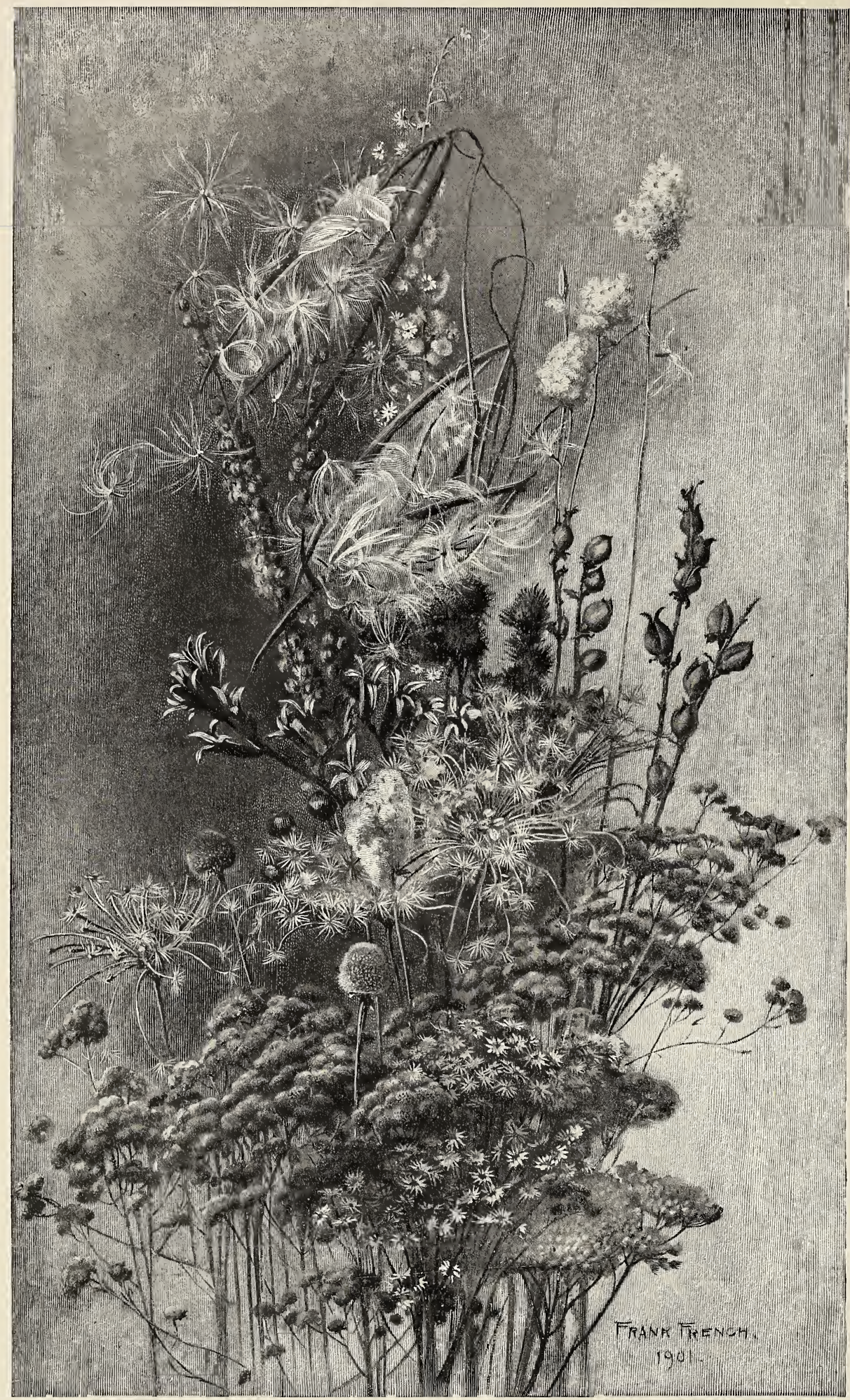

A WINTER BOUQUET 


\section{Chapter XI \\ WINTER WONDER}

$\mathbf{L}^{\mathrm{ET}}$

ET no one lay to his soul the comfortable thought, as he turns from his garden in the late fall toward the stone and iron city, that a garden amounts to precious little in winter, and that he will miss nothing pleasant in deserting the familiar ways. That, truth to tell, it will be but dank and dreary and the wind never still, and that to tread the snow-encumbered paths were the forlornest method of insuring a smart attack of the grippe.

Let him go. Duty calls, perhaps. But let his departure be miserable, a tearing of the heartstrings. For a garden in winter is a lovely thing, a place of radiant surprises, an exquisite harmony of the most delicate color tones, and a revelation of the superb drawing of tree and shrub, the marvel of their intricate design, the power and spring of their branches, and the wonderful shadows they throw. Far into December the garden is still green, for the honeysuckles will not let loose their leaves, and many a strong perennial keeps its vigor undaunted. The wise planter, also, 


\section{THE LURE OF THE GARDEN}

sees to it that certain bushes with crimson or golden twigs, and others with ivory or scarlet berries, shall burn in a chill fervor the winter through. A holly hedge is finest in cold weather, its glossy leaves and glowing berries all the richer for the half-shrouding snow; while arbor vitæ spreads its frondy branches with all of summer's energy, still yielding a pungent perfume as you crush the stiff leaflets between your fingers.

The little box borders along the paths are curiously packed with snow, the cheery little branches sticking up indomitably. And what a quaint primness distinguishes those tender shrubs and small trees which the gardener, with careful forethought, has protected from the frost in thick swathings of brown and yellow straw.

In the days of storm there is a wild singing in the trees. And a white night of moonshine and snow is worth a long journey to see. What immaculate purity, what faint grays and sharp blacks, and what an inviolable silence! Nature at rest, not tired, not discouraged, full of subtle life, at peace under the blanket of snow.

Now and then, befalling like a spell, a sudden wizardry, winter achieves its greatest miracle of beauty. Various circumstances must combine in order to insure its perfection. Occasionally not at all, but usually once or twice in a season; this miracle is 


\section{WINTER WONDER}

wrought. After a night of sleet and storm, drenching the dark world, the morning dawns fair, windless, and bitterly cold.

What unbelievable, magic metamorphosis, what labor of Aladdin's lamp! Your garden is changed into a place of strung jewels and diamond lace work. No tiny twig but bears a gem on its tip, no tracery of branch or hanging vine but makes a mesh of intricate, glittering glory, on which the sunbeams dance their wildest saraband. Gleams of violet, rose, green, and gold flash and vanish everywhere. No tree but is sheathed in shining armor, and the hedges are fantastically gorgeous with repoussé of silver and chains of burnished steel, while the eaves of the summer-house are hung with endless icicles of different lengths. Each little seed-cup is charged to the brim with frozen liquid, and tiny, glittering tassels swing on every grass-stalk.

Stand where the sun shines through a canopy of crystal branches and look about you at the miraculous garden, in its robe of a fairy queen. You will be tempted to think it even more beautiful than when June tossed her lapful of roses into it. How blue lie the shadows on the snow yonder under the shimmering spruces. How pellucidly clear and immortally fresh is the air, full of diamond "flashings, as though a myriad tiny star-sprites were fluttering their wings.

It is intoxicating. But, more's the pity, it is terrifying, too! For, should a wind come before that mag- 


\section{THE LURE OF THE GARDEN}

nificent mantle of ice is melted, fearful havoc may be wrought in the garden and the forest. As it is, many a slender bough or delicate shrub is too heavy-laden under its splendor, and may have to suffer for its hour or two of more than kingly pomp. Winter's crown is the most brilliant set upon the garden's brow, but there is danger in its gem-weighted beauty.

So you pass slowly along the radiant paths, releasing the fettered plants from their load where this is possible. The sharp crackle of the frozen snow under your feet, and the tinkle of falling ice in every direction, make a keen music that harmonizes perfectly with the silver panoply.

Toward sunset a deep rose kindles in the sky, flushing the snow-fields. A flock of snow-birds passes with a fluttering of wings, and the sparrows tweettweet under the eaves of the veranda, seeking shelter for the night. High up, a few loose golden clouds sail lightly, presaging a wind. But a wind from the south, and suddenly you realize that the temperature has already changed, is softer, milder.

An infinite number of shadows begin playing about in the garden, purple, gray, and dusky. The fountain all day has looked like a twisted little gnome changed by some waving wand into a statuette of crystal. Now it suddenly begins to murmur and complain, and the edges begin to drip, making a tender crooning. The snow is softer underfoot, and each moment some 


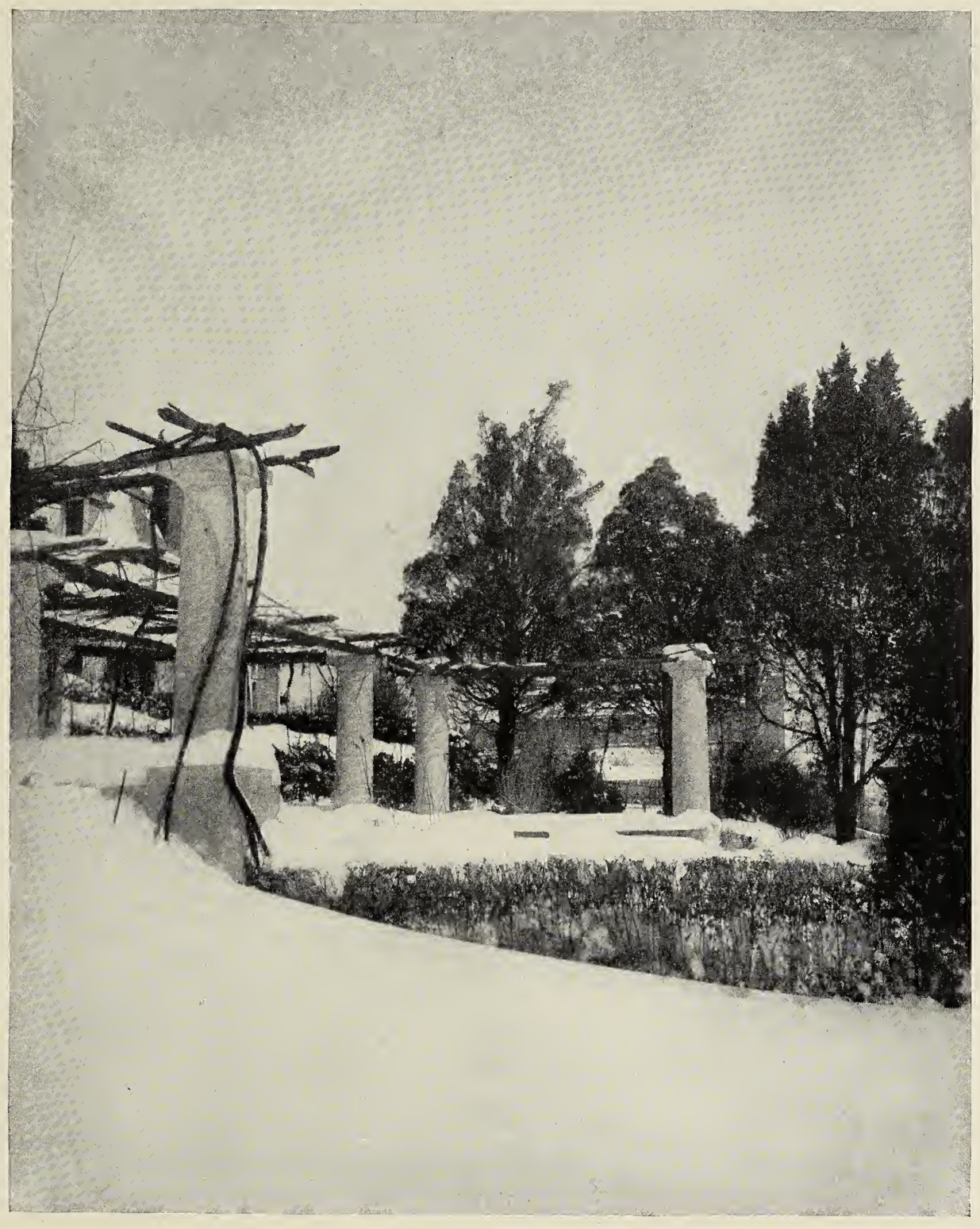

"FOR A GARDEN IN WINTER IS A LOVELY THING--." 



\section{WINTER WONDER}

branch shakes off a handful of its radiant robe, that falls with a crash and thud, while the bough springs up into place. The high tree-tops still glitter in the western light, but down in the garden the purple shadows have run close together, and a faint mist begins to form above the snow, where it lies like a veil. . .

Where you are fortunate enough to be able to stay within sight of your garden the year round, you will find many things that can be planted to enhance the winter beauty, even in our cold climate. In England, particularly in the south, monthly roses have a flower or two as late as January, and in February the crocus lights its golden lamps and the snowdrop swings her bells.

The harmonies of green possible in a plantation of firs and pines prove an unending joy. In Kentucky this " green planting" for winter has attained considerable vogue. A flaming note is lent by the cardinal, and the snow-buried evergreens, the tall hedges, and the smooth lawn-levels, with the swift crimson passing of the brilliant bird, make an unforgetable picture.

Where it is possible to have a greenhouse, the enchantment of slipping from the biting cold into the warm, moist atmosphere laden with flower perfumes and that mossy fragrance peculiar to conservatories, is hard to overestimate. There, of course, you can cultivate winter roses and violets, or indulge your fantasy 


\section{THE LURE OF THE GARDEN}

with orchids and air-plants. Best of all, you can begin to grow your annuals while without winter still commands the earth. The fascination of fooling tiny seedlings into the belief that spring has far outpaced them is one of the gardener's most pleasing deceptions. Up they rush in a panic, sticking their little leaves right and left into the humid atmosphere, hurrying into life with the haste of children rushing out to play.

And then those earliest days of the real spring, irretrievably lost to you unless you know your garden in winter. Those extraordinary, evanescent impressions, spirit-like in their impalpability, but unmistakable as the voice of the belovèd. It is impossible to cry, "Lo, here!" or, "Lo, there!" There is no precise moment upon which to clap a word or lay a hand. But on a sudden morning spring has come into your garden, creation is hard at work, the burgeoning trees and imminent flowers press on the consciousness . . and winter yields to her immortal sister in a sunillumined shower. 
POSSIBILITIES OF THE FUTURE 


\title{
THOUGHTS IN A GARDEN
}

\author{
BY ANDREW MARVEL
}

How vainly men themselves amaze

To win the palm, the oak, or bays,

And their incessant labours see

Crowned from some single herb or tree, Whose short and narrow-vergèd shade Does prudently their toils upbraid;

While all the flowers and trees do close

To weave the garlands of Repose.

Fair Quiet, have I found thee here, And Innocence, thy sister dear? Mistaken long, I sought you then In busy companies of men:

You sacred plants, if here below, Only among the plants will grow: Society is all but rude To this delicious solitude. . . .

How well the skilful gardener drew Of flowers and herbs this dial new! Where, from above, the milder sun Does through a fragrant zodiac run: And, as it works, th' industrious bee Computes its time as well as we.

How could such sweet and wholesome hours Be reckoned, but with herbs and flowers! 


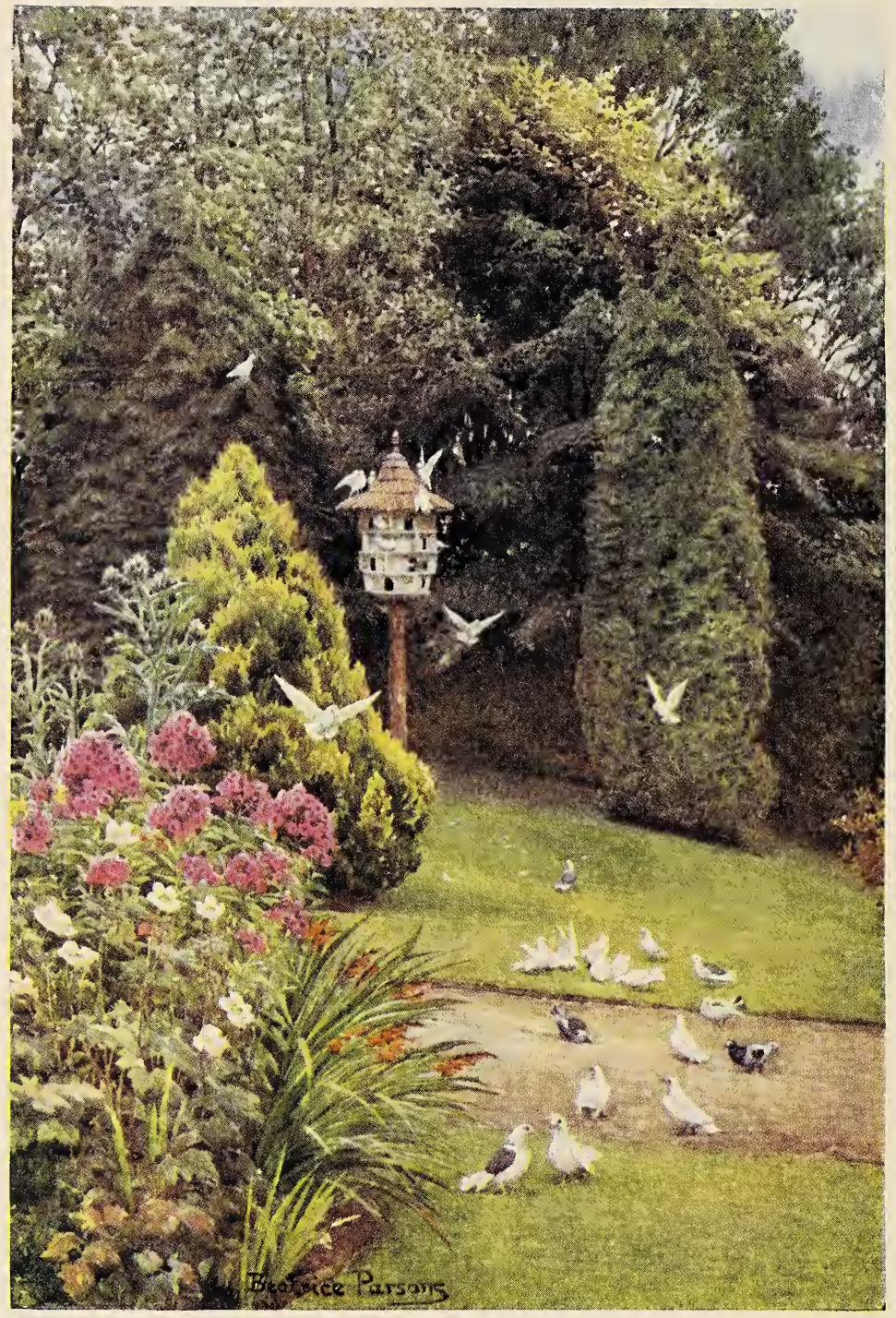




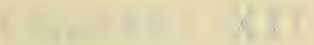

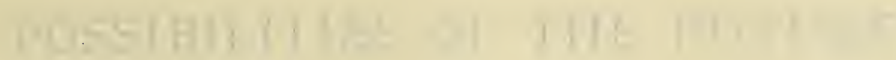

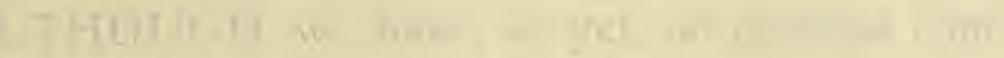

1
y

2.

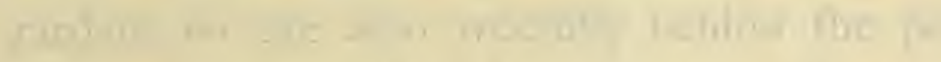

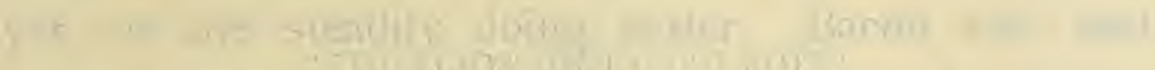

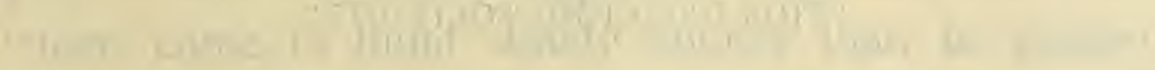

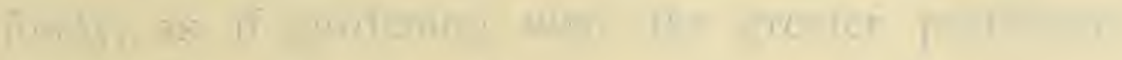

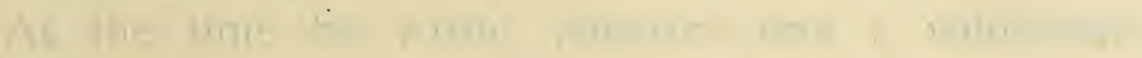

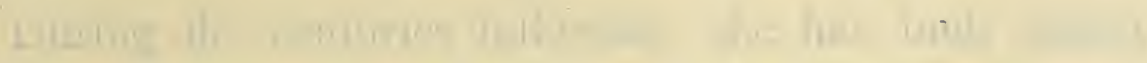

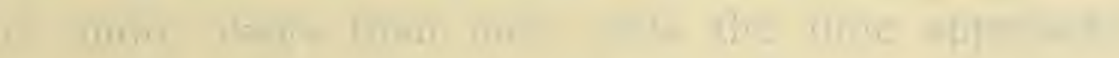

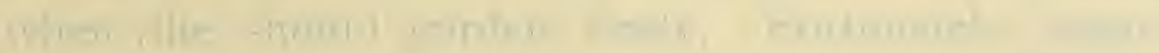

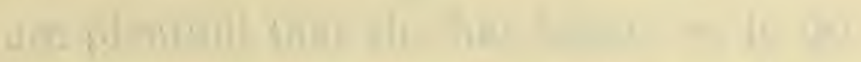

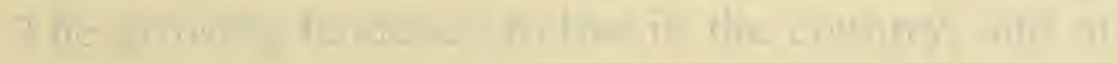

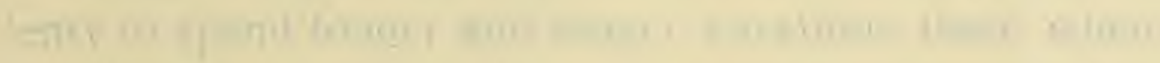

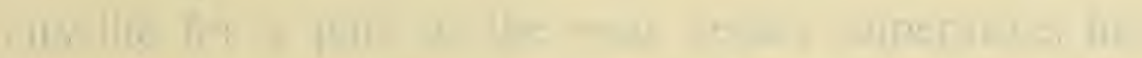

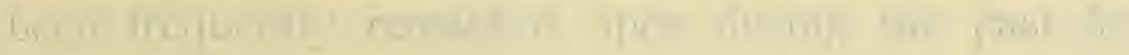

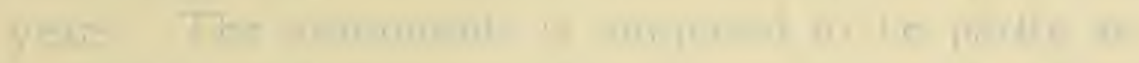

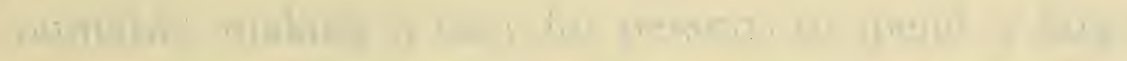

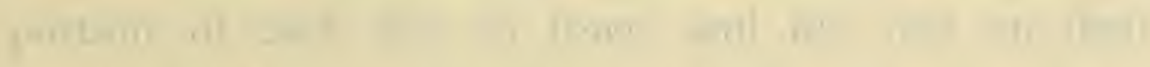

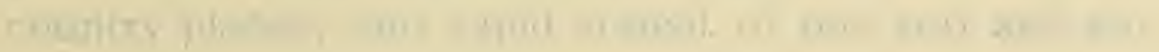


"THIS DELICIOUS SOLITUDE." 


\section{Chapter XII}

\section{POSSIBILITIES OF THE FUTURE}

1 LTHOUGH we have, as yet, no gardens comparable to the best in England, Italy, or 1 France, and though in the matter of small gardens we are also woefully behind the possibilities, yet we are steadily doing better. Bacon said that "men come to build stately sooner than to garden finely, as if gardening were the greater perfection." At the time he wrote, America was a wilderness. During the centuries following, she has built stately in more ways than one; now the time approaches when she should garden finely. Fortunately, signs are plentiful that she has begun so to do.

The growing tendency to live in the country, and at least to spend longer and longer vacations there when city life for a part of the year seems imperative, has been frequently remarked upon during the past few years. The automobile is supposed to be partly accountable, making it easy for persons to spend a large portion of each day in town, and the rest on their country places; and rapid transit of one sort and an- 


\section{THE LURE OF THE GARDEN}

other, and of varying degrees of efficiency, has made of the suburbanite an ever-increasing multitude. As for the suburban garden, it holds delightful potentialities, more than a few having already been realized.

Moreover, the long and desperate reign of ugliness is waning, and scarcely an American village, town, or city but is bestirring itself in the sacred cause of beauty. The women's clubs and municipal committees are doing a great work in turning waste and hideous places into little parks, public gardens, and playgrounds. School children everywhere are being taught the value of order and loveliness in their surroundings, given opportunities to plant and cultivate gardens of their own, and encouraged to influence their families toward improving the home yard and combining for the public betterment of streets, avenues, and squares.

Straws all these, but blowing decidedly in one direction. Not a tree planted in a city street that is not an object-lesson, creating a demand for others. And one back yard transformed into a garden begets many more of its kind. Make one beautiful place in a town, and a hundred will follow in due course. People are ready for the hint!

The idea of seclusion as an essential part of a garden, is also a thing of slow, but sure, growth. At present we are most of us far too much afraid of walls, too fond of having the eye of the world on our possessions, too careless of the privacy that makes a 


\section{POSSIBILITIES OF THE FUTURE}

part of every human life; careless of maintaining our own, careless of invading that of others.

A town need not be unlovely nor even monotonous because its gardens are hidden. On the contrary, garden walls and gates, as a previous chapter endeavored to establish, can be wonderfully beautiful and various, assisting successfully in making the streets unique and picturesque. In the open country, hedges and fences not too easily seen through are sufficiently protective, and are capable of adding greatly to the charm of country roads; while no town of considerable size should be satisfied until it possesses well-planned and carefully kept up public gardens.

The little city of St. George, in Bermuda, is an excellent example of the beauty to be attained by walled town gardens. The quaint, narrow streets run between walls of varying height, over which fall the flaming branches of hibiscus or the long purple streamers of bougainvillea. And everywhere arched or pillared gateways lend sudden, surprising glimpses of the delightful gardens within those walls. Now and again one comes upon an enchanting court separated from the street by charming arches and paved with the omnipresent white coral, while within, a tree throws its shade over narrow beds of white lilies against white walls, or the intense scarlets of geranium, pomegranate, and hibiscus kindle the whole to radiance.

No arrangement of open spaces conventionally 


\section{THE LURE OF THE GARDEN}

planted, as obtains so much here in the suburbs, can ever produce the imaginative and suggestive loveliness to be gained by surrounding the gardens with walls. It is the elusive, the half-revealed, that is always the more alluring. And just as the old garden-makers insisted that no garden should be so laid out or planted as to be visible from any one spot, but should hide behind hedges and boskets, have hidden recesses and paths curving out of sight, so, too, the town that hints at hidden, lovely places removed from the general observation, will still prove the more beautiful, though, nay, because, so much of its beauty is concealed.

Many American places upon which both time and money have been spent fail in another essential, that of harmony. Too often there has been no attempt made at suiting the house to the grounds, nor any study of the general environment, its possibilities, its drawbacks, and its characteristic quality undertaken. Yet harmony alone will excuse many a shortcoming. Nothing exists solely for itself, and in making a country place, the closer the co-relation between the house, the garden, and the surrounding lay of the land, the happier the result. An Italian villa with formal grounds set in the middle of a bleak and bare New England coast-line, where the embattled rocks are forever flinging back a furious sea, will never create in the beholder that feeling of satisfaction which a place, perhaps less lovely in itself, but belonging more intimately with its 


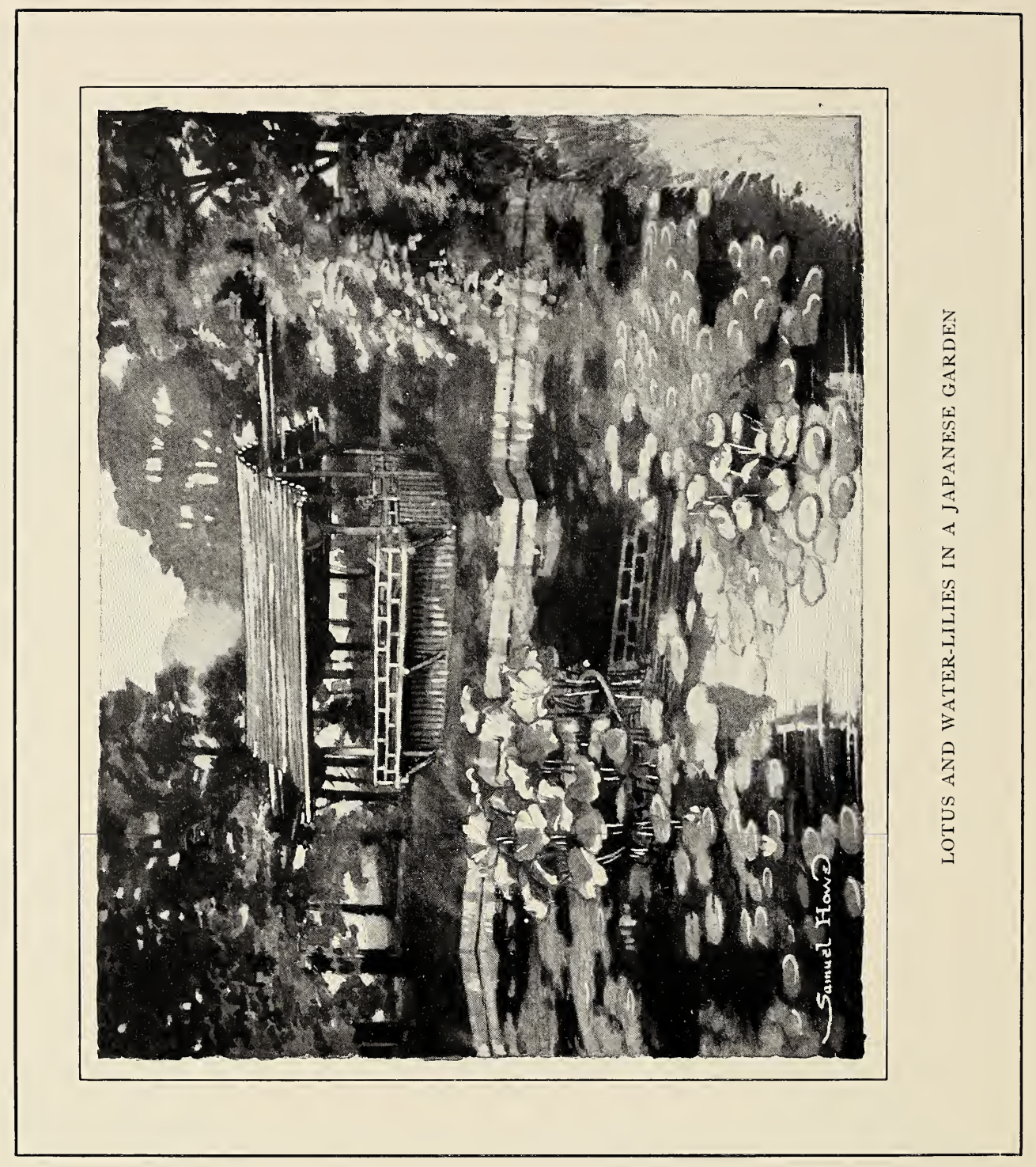




\section{POSSIBILITIES OF THE FUTURE}

setting, will induce. The best places acknowledge the fatherhood of the country about them, adapting the natural aspect to their own uses, but neither ignoring nor violating it.

It is only when the people at large take to doing anything that an actual vitality ensues, and, therefore, the most encouraging symptom of a new garden era lies in the general interest perceptible in many directions. There are the numerous and successful books and magazines of a technical sort, for instance, addressed to persons whose chief asset is a personal enthusiasm for improving whatever lies at hand and a readiness to undertake the labor of laying out and cultivating a small place with their own hands. The garden triumphant! Delightful thought. It is this same general desire that has long existed in England, and that has put her so far ahead of us in the matter of gardens. Even in the use of window boxes, the English towns exceed anything done here. London, during the season, looks like a flower garden stood on end, so ubiquitous are these tiny flower beds. The English man or woman must have flowers, cannot get along without them where there is the least chance to make them grow. And precisely at the moment when an Englishman becomes possessed of a bit of ground, a garden begins to evolve.

The American tendency for doing everything in a hurry, and without a feeling for the permanence of 


\section{THE LURE OF THE GARDEN}

what is accomplished, is perhaps the garden's deadliest enemy. You cannot hasten nature beyond a certain point, and a large part of a garden's charm is only attained through the passage of time. But many among us do not stay in any one place for more than a year or two. The "step lively" of the trolley-car conductor is the shibboleth of our lives; here to-day and gone tomorrow. Quick effects and quick results are what we want. We cannot plant for ourselves, and why should we plant for others? We must acquire leisure and stability, and the desire for a home rather than a series of stepping-stones, before we become makers of gardens.

The gardens made by our forefathers bespeak this lost quality of repose, a quality inherent in them despite the energy with which they confronted and subdued the wilderness. For repose by no means excludes energy. There is no need of being splendidly null because of achieving a degree of serenity. The ability to sit still and wait is a valuable one; for much most worth while in our life must either be awaited or else entirely missed.

As this realization grows in us, we shall become not only more quiet, but more simple. We need to strike a balance, to learn that we can do all we have to do, howsoever strenuous the task, and yet have time enough to drop it all out of our minds for at least a part of each day. Instead of devoting our whole 


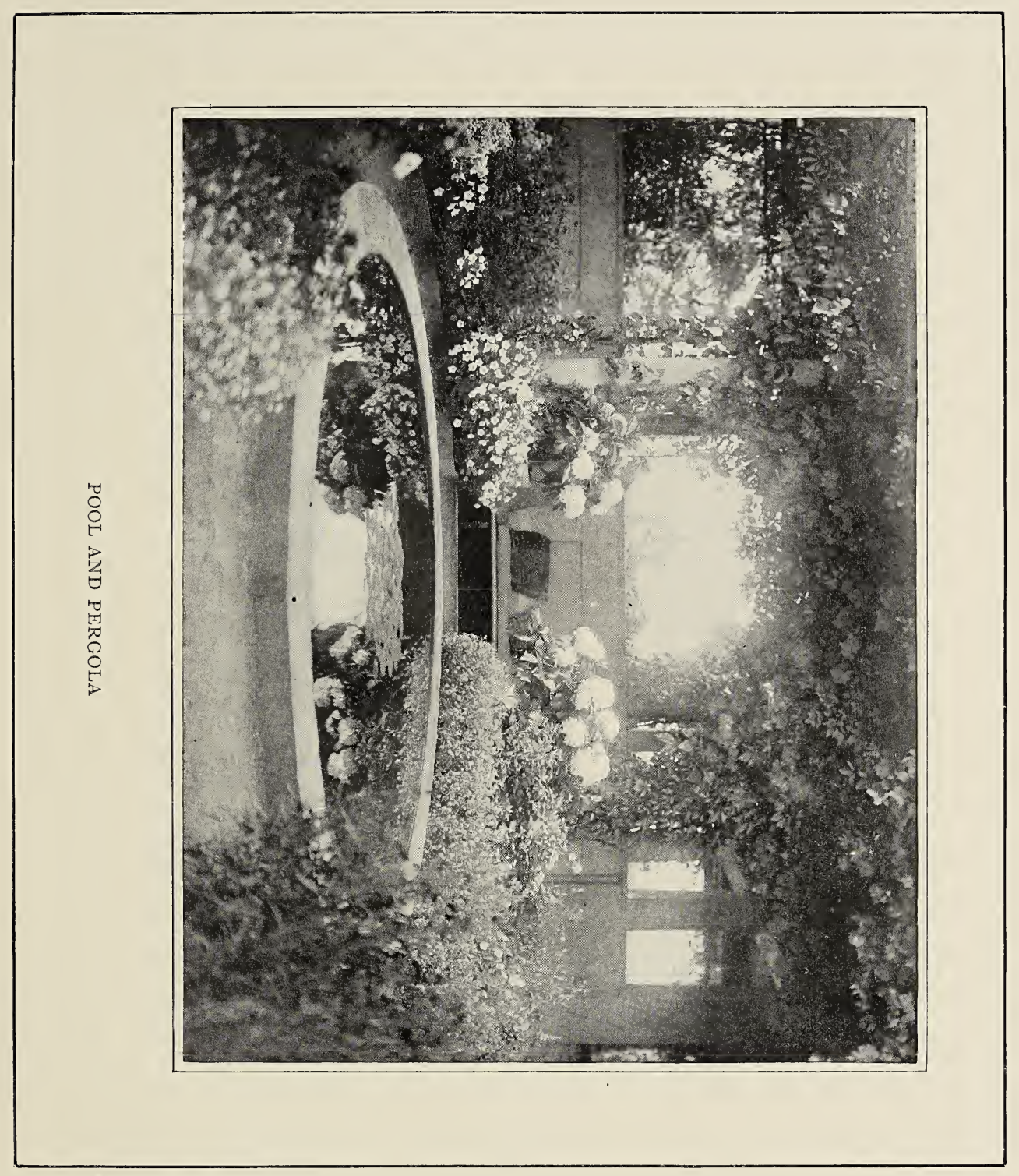





\section{POSSIBILITIES OF THE FUTURE}

energy to getting more, we shall begin to set about enjoying what we already have; and the feverish pace of our pulses will drop to a normal and healthier beat.

The era of the man entirely wrapped up in his business is passing. He is, after all, only partly a man. Remove him from his daily task, his office seat, and nothing is left for him but to die, to stop running, like a machine whose single motive power has ceased. The young man of to-day is more concerned in giving his faculties free play, in fulfilling himself in as many directions as possible. He may be, and usually is, a specialist so far as his work is in question; but he does not allow his work to swamp him. Art, philosophy, and play enter into the scheme of his conception, and he is likely to prove a far better citizen than his father before him, as well as a happier one.

As for women, their wider activities nowadays make them the more desirous of a contrasting peace. The number of women earning their own way who lay aside something with the object of eventually owning a little place in the country is surprisingly large. Women have always loved gardens, and the fact that they are becoming more able to get what they want is going to put many a woman in the center of an exquisitely tended acre or two who would formerly have been obliged to fret her soul out in a boarding-house, or, at the best, content herself with sharing the home of a more fortunate sister. Many a sweet seaside garden 


\section{THE LURE OF THE GARDEN}

or terraced hill-slope around a tiny bungalow or hidden spot near the town are the work and the joy of single women. Costing little, but yielding much, these oases are charming evidence of a new birth in garden history, and seem destined to spread all over the continent, drawing recruits from the ranks that used to fill the rocking-chairs on the verandas of summer hotels, from the idle as well as from the busy.

So it is that those of us who particularly love gardens look forward comfortably to the next ten or fifteen years as a time when there will be much digging and planting and training up of vines. Much improvement, too, in garden architecture, and the gradual substitution of taste for ostentation in the estates of the wealthier among us. The day is not far off, its sunshine is already upon us, when each suburban house will have its secret garden, whispering over the wall or through the gate to the world outside, possibly joining openly with the general scheme in front, but keeping somewhere a real "close" planted with the finest of the flowers and sheltered from all but the most intimate. An hour in such a spot is filled with balm and potent for the refreshment of worn bodies and harassed minds.

Let nobody misprise a garden, or think it not worth the trouble it costs. For this is part of the enchantment, that the very trouble becomes delectable, the pulling of weeds as keen a pleasure as cutting roses, 


\section{POSSIBILITIES OF THE FUTURE}

the planning of a new bed, the setting of a sun-dial, or the trimming of a hedge pleasures so intense that the mind turns to them from the dominion of the city desk or the giddy center of the social whirl with a longing not to be quelled.

Indeed, it might not be amiss to inscribe over every garden the legend: "Whosoever enters here, let him beware. For he shall never more escape, nor be free of my spell." 

. 



